Universidade de Brasília - UnB

Departamento de Saúde Coletiva - DSC

Programa de Pós-Graduação em Saúde Coletiva - PPSC

\title{
ALCOOLISMO ENTRE O POVO AKWẼ-XERENTE, CAUSAS, CONSEQUÊNCIAS E TRATAMENTO: O QUE PENSAM OS PROFISSIONAIS DE SAÚDE?
}

\author{
Renzo Gonçalves Chaves
}

ORIENTADOR:

Prof'. Dro. Claudio Fortes Garcia Lorenzo

Brasília, 2016 
Universidade de Brasília - UnB

Departamento de Saúde Coletiva - DSC

Programa de Pós-Graduação em Saúde Coletiva - PPSC

Renzo Gonçalves Chaves

\section{ALCOOLISMO ENTRE O POVO AKWẼ-XERENTE, CAUSAS, CONSEQUENCIAS E TRATAMENTO: O QUE PENSAM OS PROFISSIONAIS DE SAÚDE?}

ORIENTADOR:

Prof $^{0}$. Dr ${ }^{0}$. Claudio Fortes Garcia Lorenzo

Dissertação apresentada ao Programa de PósGraduação em Saúde Coletiva, Universidade de Brasília, como requisito parcial para obtenção do Grau de Mestre, área de concentração Saúde, Cultura e Sociedade. 
Renzo Gonçalves Chaves

\title{
ALCOOLISMO ENTRE O POVO AKWẼ-XERENTE, CAUSAS, CONSEQUÊNCIAS E TRATAMENTO: O QUE PENSAM OS PROFISSIONAIS DE SAÚDE?
}

\author{
COMPOSIÇÃO DA BANCA AVALIADORA
}

\section{CLAUDIO FORTES GARCIA LORENZO}

Doutor - Universidade de Brasília (UnB) - Presidente

XIMENA PAMELA BERMUDÉZ

Doutora - Universidade de Brasília (UnB) - Membro Efetivo Interno

\section{LUCIANA BENEVIDES FERREIRA}

Doutora - Ministério da Saúde - Membro Efetivo Externo

HELENA ERI SHIMIZU

Doutora Universidade de Brasília (UnB) - Membro suplente 
É preciso sentir a necessidade da experiência, da observação, ou seja, a necessidade de sair de nós próprios para aceder à escola das coisas, se as queremos conhecer e compreender. Émile Durkheim 
Deus é bom e suas misericórdias duram para sempre! Agradeço a Deus por suas infinitas bênçãos, por estar comigo nos momentos mais difíceis e alimentar minha fé quando eu já não tinha mais fé.

A minha querida esposa Elaine, por suportar com persistência à tempestade e aguardar a calmaria. Obrigado por compartilhar comigo este maravilhoso sonho.

Aos meus filhos amados Lucas, Felipe e Isabela, por serem minha fonte infinita de inspiração.

Agradeço profundamente ao meu orientador Cláudio Lorenzo, pela mansidão e benignidade com que conduziu este trabalho. Obrigado por sua sensibilidade e sabedoria.

Aos meus queridos “pais" Fátima, Edmilson, Aroldo, Didida e Didido por estarem tão perto de mim nos momentos de turbulência e me apoiarem na conquista deste projeto.

Aos colaboradores desta pesquisa, por compartilharem com tanta dedicação seus conhecimentos, anseios e expectativas. 


\section{Resumo}

O consumo do álcool é alto e bastante presente no cotidiano das pessoas, pois a inserção da substância alcoólica em nossa sociedade foi naturalizada, principalmente quando em festas e comemorações, eventos associados a questões valorizadas socialmente como prazer, liberdade e lazer. Portanto, beber é uma prática socialmente construída a partir de vários grupos; todavia o estabelecimento dos limites entre o consumo recreativo e o uso contínuo até a dependência é o grande desafio de enfrentamento do consumo da bebida alcoólica em nossa sociedade. Dessa forma, para compreender os processos de beber das comunidades indígenas, de maneira particular, é fundamental ter clareza acerca dos fenômenos dos diversos usos e abusos da ingestão; e, para isso, é preciso deslocar o problema do campo físico-individual para o coletivo-social, enfatizando a importância da apreensão do significado do beber para as múltiplas culturas e sociedades. Nesse sentido, o uso abusivo da bebida alcoólica é concebido neste estudo como algo complexo, resultante de vários fatores socioculturais que determinam vários comportamentos relacionados à ingesta destas substâncias, bem como a criação dos estereótipos, sendo talvez o mais atroz de todos. Logo, é de grande valia a investigação e análise dos discursos dos profissionais de saúde indígena acerca do uso e abuso da bebida alcoólica entre os Akwẽ-Xerente, pois há uma escassez de estudos sobre este consumo junto a este povo e seus resultados podem ajudar ao planejamento específico de ações no contexto Akwẽ-Xerente, bem como trazer subsídios ao desenvolvimento de projetos de capacitação profissional. Este trabalho pretende então investigar as percepções dos profissionais de saúde que atuam entre o povo Akwẽ-Xerente no município de Tocantínia-Tocantins sobre o uso e o abuso da bebida alcoólica e sobre a qualidade da atenção à saúde para a prevenção e assistência a esse fenômeno. Trata-se de estudo de natureza qualitativa por meio de entrevistas semiestruturadas e posterior análise dos discursos dos profissionais de saúde, utilizando-se a metodologia do Dialética Hermenêutica de Minayo. Este estudo demonstrou que o indígena Akwẽ-Xerente está suscetível aos efeitos da bebida alcoólica e a causa do consumo abusivo está no campo das perdas das funções sociais laborais; modificação do padrão de uso e facilidade de acesso pela aproximidade com a cultura ocidental e inabilidade intrínseca do indígena em lidar com conflito. Como consequências, observou-se a agressividade; a perda da função provedora; o reforço do preconceito e as doenças físicas. Isso se deve ao fato de o processo do contato intercultural com a sociedade ocidental ter ocasionado uma mudança de comportamento e de significado do próprio ato de beber nessa comunidade. Observou-se que ainda não há ações efetivas voltadas para a formação dos profissionais de saúde visando inibir o uso abusivo da bebida alcoólica entre os AkwẽXerente por parte dos serviços em saúde e que existe uma crítica construída no discurso dos profissionais na admissão do problema, contudo as estratégias de enfrentamento são incipientes.

Palavras-chave: Povos indígenas; Alcoolismo; Atenção à Saúde, Políticas Públicas. 


\begin{abstract}
Alcohol consumption is high and very present in daily life, because the insertion of the alcoholic substance in our society was naturalized, especially when at parties and celebrations, events associated with valued social issues as pleasure, freedom and leisure. So drinking is a practice socially constructed from various groups; however the establishment of boundaries between recreational use and continued use to addiction is the great challenge of coping of alcohol consumption in our society. Thus, to understand the drinking process of indigenous communities, in a particular way, it is essential to be clear about the phenomena of the various uses and abuses of intake; and for that, we need to shift the problem of physicalindividual field to the collective-social, emphasizing the importance of seizing the meaning of the drink to the multiple cultures and societies. In this sense, the abuse of alcohol is designed in this study as a complex resulting from various socio-cultural factors that determine various behaviors related to the intake of these substances, as well as the creation of stereotypes, and perhaps most atrocious of all. Therefore it is of great value to research and discourse analysis of indigenous health professionals about the use and abuse of alcohol among the AkweXerente because there is a lack of studies on this consumption with this people and its results can help to specific planning actions in Akwe-Xerente context and to provide support to the development of professional training projects. This work intends to then investigate the perceptions of health professionals who work among the Akwe-Xerente people in TocantíniaTocantins municipality on the use and abuse of alcohol and the quality of health care for the prevention and assistance to this phenomenon. This is qualitative study using semi-structured interviews and subsequent analysis of the discourses of health professionals, using the methodology of the Dialectic Hermeneutics of Minayo. This study demonstrated that the Akwe-indigenous Xerente is susceptible to the effects of alcohol and the cause of abuse is in the field of loss of employment social functions; standard modification of use and ease of access by the closeness with Western culture and the indigenous intrinsic inability to deal with conflict. As a consequence, there was aggressiveness; the loss of provider function; the reinforcement of prejudice and physical illnesses. This is because the process of intercultural contact with Western society have caused a change in behavior and significance of drinking itself in this community. It was observed that there is still no effective actions for the training of health professionals aiming to inhibit the abuse of alcohol among the Akwe-Xerente by the services in health and that there is a critical built in the professional discourse on admission of the problem however the coping strategies are incipient.
\end{abstract}

Keywords: Indigenous People; Alcoholism ; Health Care, Public Policies 


\section{LISTA DE FIGURAS}

Figura 1 Relação do Consumo de Álcool e Problemas.................................................... 27

\section{LISTA DE QUADROS}

Quadro 1 - Óbitos p/Residência segundo Região..................................................... 28

Quadro 2 - Internações segundo Região................................................................. 28

Quadro 3 - Óbitos p/Residência segundo Capítulo CID-10..................................... 28 


\section{LISTA DE ABREVIATURAS E SIGLAS}

AIS Agentes Indígenas de Saúde

AVC Acidente Vascular Cerebral

CAPS AD Centro de habilitação Psicossocial em Álcool e Drogas

CEBRID Centro Brasileiro de Informações Sobre Drogas Psicotrópicas

CID Código Internacional de Doenças

CISA Centro de Informações sobre Saúde e Álcool

DSEI Distritos Sanitários Especiais Indígenas

EJA Educação de Jovens e Adultos

EMSI Equipe Multidisciplinar de Saúde Indígena

FUNASA Fundação Nacional de Saúde

FUNAI Fundação Nacional do Índio

IBGE Instituto Brasileiro de Geografia e Estatística

MS Ministério da Saúde

PNASI Política Nacional de Saúde Indígena

SDAS Síndrome de Dependência do Álcool

SESAI Secretaria Especial de Saúde Indígena

SIASI Sistema de Informação a Assistência de Saúde

SUS Sistema Único de Saúde 
1. INTRODUÇÃ O.......................................................................................................... 11

2. JUSTIFICATIVA..................................................................................................... 14

3. OBJETIVOS................................................................................................................. 15

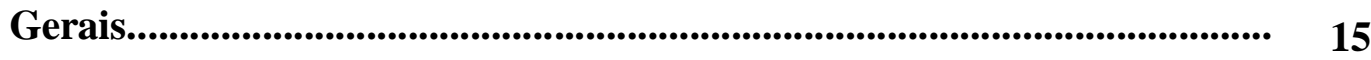

Específicos.................................................................................................................. 15

4. REVISÃO DE LITERATURA E QUADRO TEÓRICO-CONCEITUAL.... 16

4.1 Uso e Abuso de Álcool: Impactos sobre a Vida Social e sobre a Saúde Pública.

4.2. O Uso e o Abuso de Álcool entre os Povos Indígenas Brasileiros....... 25

4.3 A Política Nacional de Saúde Indígena e o Subsistema de Saúde diante do Problema do Uso e Abuso de Álcool pelos Povos Indígenas

4.4 O Povo Akwẽ-Xerente e o uso Abusivo de Álcool................................ 40

5. O PERCURSO METODOLÓGICO DA PESQUISA................................... 46

5.1 Seleção e Recrutamento dos Colaboradores de Pesquisa e Roteiro de Entrevista.

5.2 O Caminho para Interpretação dos dados gerados.............................. 49

6.RESULTADOS E DISCUSSÃO

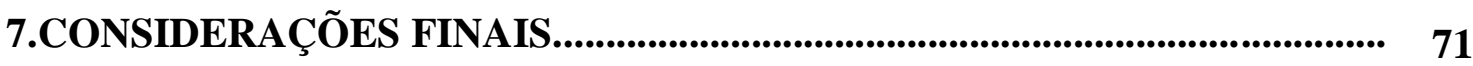

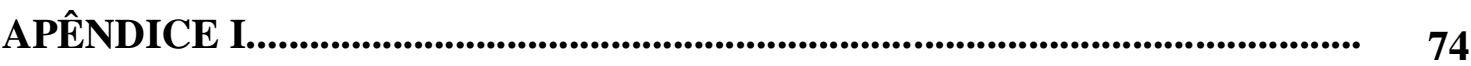

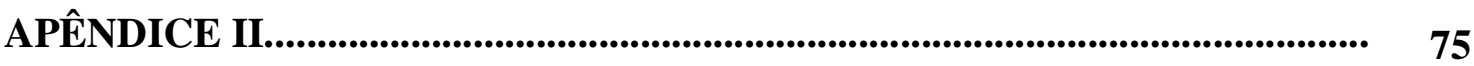

REFERENCIAL 


\section{INTRODUÇÃO}

Por décadas, vários estudos que abordaram os desfechos acerca do consumo da bebida alcoólica entre os povos indígenas no Brasil revelaram o descumprimento da Lei 6.001, de 19 de dezembro de 1973, a qual considerava crime contra os índios e a sua cultura, propiciar, por qualquer meio, a aquisição, o uso e a disseminação da bebida alcoólica nos grupos tribais ou entre índios não integrados (MAGALHÃES, 2005; AURELIANO \& MACHADO JR.; 2012). Embora essa Lei tenha sido revogada a partir da Constituição Federal de 1988, os desdobramentos acerca do uso e do abuso da bebida alcoólica entre os povos indígenas são ainda relevantes e passíveis de discussão por refletir uma ameaça nos contextos biopsicossociais entre vários povos indígenas no Brasil (BRASIL, 1973; COIMBRA JR. et. al., 2003).

O censo demográfico realizado pelo IBGE em 2010 aponta uma população total de aproximadamente 817.963 indígenas dos quais 502.783 vivem na zona rural e 315.180 habitam as zonas urbanas brasileiras. Segundo a FUNAI (2016), eles representam 305 diferentes etnias e mais de 274 línguas indígenas distintas, tendo o contingente de brasileiros que se considerava indígena crescido $150 \%$ na década de 90 , em ritmo.

Lacerda (1999) aponta a bebida alcoólica como a droga mais amplamente utilizada no mundo e o processo de alcoolização como um fenômeno acompanhado de um conjunto de manifestações sociais tanto positivas quanto negativas marcadas pela imprecisão de diagnóstico. Outros estudos constatam ainda que o uso e o abuso do álcool, algumas das vezes, servem como um catalisador de atos agressivos ou auto agressivos motivadores de ações delituosas como homicídios, delitos sexuais, maus-tratos, entre outros problemas sociais (MATHEW, 1992 apud MARQUES, 2001; COLOMA, 2001; NIEWIADOMSKI, 2004; SOUZA, 2005). Desse modo, conforme Bucher (1991) e Lacerda (1999), a dependência do álcool, junto com a do tabaco, é avaliada como um dos principais problemas da Saúde Pública no Brasil.

A Síndrome de Dependência de Álcool foi incorporada como patologia a partir da $8^{\mathrm{a}}$ Conferência Mundial de Saúde em 1986, o que determinou aos países membros a elaboração de ações governamentais embasadas por políticas de Estado para sua prevenção e enfrentamento. No Brasil, a Política do Ministério da Saúde para a Atenção Integral a Usuários de Álcool e outras Drogas priorizou ações de caráter terapêutico, preventivo, educativo e reabilitador, direcionadas às pessoas que fazem uso de álcool e de outras drogas. 
Cabe salientar que nenhum dos documentos que normatizam essas ações e estratégias no Brasil possuem caráter intercultural explícito, ficando assim a lacuna da ausência documental de condutas diferenciadas, apesar de estar estabelecido que os resultados da interação do indivíduo com outro ambiente social e com outras culturas são fatores de influência no ato de consumir a bebida alcoólica.

Já está bem demonstrado que a Síndrome de Dependência do Álcool atinge também os Povos Indígenas e potencialmente com mais frequência e gravidade aqueles que possuem um relacionamento mais estreito com a população não indígena de suas respectivas regiões. Logo, os fatores de contato podem causar maior ou menor propensão para que as pessoas tornem-se ou não dependentes do álcool visto que no meio ambiente social e cultural incluem-se fatores de grande valia como, por exemplo, "o que as pessoas compreendem sobre o álcool”; "as regras locais sobre o consumo"; "origem das bebidas"; "ocasiões adequadas ou não ao consumo" (Souza, Oliveira e Kohatsu 2005). Somando-se a isso, temos ainda as histórias pessoais e familiares (grupal), bem como as condições econômico-sociais e outros elementos socioculturais relacionados ao consumo de bebidas, que podem, consoante os autores, também gerar o uso abusivo da droga e os seus desdobramentos.

Souza e Garnelo (2006), considerando o contexto dos povos indígenas, argumentam que definir quem? e o que é alcoolista/alcoolismo? não é uma tarefa fácil, dada as suas nuances subjetivas e os diversos conjuntos de diagnósticos que vão desde o conceito e classificação de dependência, abstinência e abuso da bebida alcoólica (entendido pelos autores como o uso excessivo, porém não continuado) até o conceito de intoxicação por álcool (entendida pelos autores como o estado de embriaguez). Está claro também para essa autora, que o contato intercultural propiciou a introdução da bebida destilada nas comunidades indígenas, ocasionando mudanças na organização dessas sociedades e transformações mais amplas na sua cultura (SOUZA e GARNELO, 2007; OLIVEIRA, 2009).

Lorenzo (2011) discute a necessidade de uma proposta complementar e diferenciada de organização dos serviços de saúde indígena e, principalmente, de formação do profissional de saúde indígena ancorada no conhecimento e no respeito aos sistemas de representações de saúde tradicionais articulando, dialogicamente, quando necessário, as práticas do modelo de saúde ocidental com os valores e as práticas dos povos indígenas. Em seu trabalho, o autor considera as especificidades culturais no desenvolvimento e no uso das tecnologias 
apropriadas para o Modus operandi das equipes de saúde que atuam nas "diferenças", imersas no saber intercultural da medicina "tradicional" e "convencional ou ocidental".

Para realizar qualquer ação de intervenção em relação à redução dos possíveis danos causados pelo uso e abuso da bebida alcoólica pelos povos indígenas, é preciso então compreender a especificidade cultural e histórica de cada grupo, assim como o significado do ato de beber para cada indivíduo ou etnia. Ou seja, "entender que o uso da bebida alcoólica é um fenômeno cultural e não apenas uma doença”. No mesmo sentido, é preciso ter em conta, como pontua Ferreira (2009) que a atuação das equipes de saúde junto às populações indígenas, precisam partir da aceitação das comunidades e lideranças, única forma de legitimá-las.

Dessa forma, para serem aceitos pela comunidade indígena e atuar nas "diferenças" respeitando a interculturalidade, os profissionais de saúde indígena precisam melhor compreender os aspectos culturais e sociais relacionados ao o uso e/ou abuso da bebida alcoólica entre os povos indígenas em um dado contexto específico.

Da exploração desse problema com base nos contextos e conhecimentos descritos emergiram as seguintes questões de partida para a presente pesquisa: 1. Qual a percepção que os profissionais que atuam na Saúde Indígena têm sobre as causas e consequências do consumo e o abuso da bebida alcoólica entre o povo Akwẽ-Xerente? 2. Como eles compreendem as ações preventivas e terapêuticas no âmbito de seus serviços e do sistema de saúde como um todo?

A pesquisa tem, portanto, como finalidade investigar as percepções e ideias dos profissionais de saúde indígena sobre o uso elou abuso da bebida alcoólica entre os AkweXerente que habitam as terras indígenas no município de Tocantínia-TO, Tocantins e sobre a qualidade da atenção de saúde que é dirigida ao problema. 


\section{JUSTIFICATIVA}

Já foi apontada pela literatura a necessidade imperativa de mais pesquisas que permitam melhor dimensionamento de impactos do problema do alcoolismo entre os povos indígenas e melhor caracterização das especificidades culturais desses povos com o intuito de superar as limitações no desenvolvimento de ações preventivas e de propostas de trabalho em saúde adequadas a essa inserção cultural e comunitária (GUIMARÃES e GRUBITS, 2007; LANGDON, 2001). Assim, é de grande valia a investigação e análise dos discursos dos profissionais de saúde indígena acerca do uso e abuso da bebida alcoólica entre os AkwẽXerente, pois há uma escassez de estudos sobre este consumo junto a este povo e seus resultados podem ajudar ao planejamento específico de ações no contexto Akwẽ-Xerente, bem como trazer subsídios ao desenvolvimento de projetos de capacitação profissional. 


\section{OBJETIVOS}

Geral:

- Investigar as percepções dos profissionais de saúde que atuam entre o povo Akwẽ-Xerente no município de Tocantínia-Tocantins sobre o uso e o abuso da bebida alcoólica e sobre a qualidade da atenção à saúde para a prevenção e assistência a esse fenômeno.

Específicos:

- Investigar as percepções dos profissionais de saúde sobre as causas e consequências do consumo e o abuso da bebida alcoólica entre os AkwẽXerente.

- Investigar as percepções dos profissionais de saúde sobre a qualidade da atenção prestada para prevenção e terapêutica ao abuso de álcool e Síndrome de Dependência em suas unidades.

- Avaliar a visão desses profissionais em relação ao Sistema de Saúde como um todo e políticas públicas dirigidas ao problema.

- Investigar como está construída a visão dos profissionais sobre o povo AkwẽXerente no âmbito das relações interculturais. 


\section{REVISÃO DE LITERATURA E QUADRO TEÓRICO-CONCEITUAL.}

\subsection{USO E ABUSO DE ÁlCOOL: IMPACTOS SOBRE A VIDA SOCIAL E SOBRE A SAÚDE PÚBLICA.}

De acordo com o Centro de Informações sobre Saúde e Álcool- CISA (2014) acreditase que a bebida alcoólica teve sua origem na Pré-História, durante o período Neolítico, quando houve a aparição da agricultura e a invenção da cerâmica. A partir de um processo de fermentação natural, ocorrido há aproximadamente 10.000 anos, o ser humano passou a consumir e a atribuir diferentes significados ao uso do álcool.

Marques (2001), ao resgatar o cenário histórico do consumo do álcool, considera o álcool como a droga psicoativa mais utilizada pela humanidade, citada até nos achados bíblicos. O consumo da bebida alcoólica e advertências contra o abuso ocorrem em vários livros bíblicos como, por exemplo, em Provérbios (20:1) "O vinho é zombador e a bebida fermentada provoca brigas; não é sábio deixar-se dominar por eles". Advertências como essas aparecerem em várias passagens e revelam que, desde os primórdios, as sociedades possuem grandes dificuldades no estabelecimento dos limites entre o consumo recreativo e o uso/abuso da bebida alcoólica.

Assim, desde os primórdios, o consumo do álcool é alto e bastante presente no cotidiano das pessoas; pois a inserção da substância alcoólica em nossa sociedade foi naturalizada, principalmente quando em festas e comemorações, eventos associados a questões valorizadas socialmente como prazer, liberdade e lazer (SANTOS e MARTIN, 2009). Beber é uma pratica socialmente construída a partir de vários grupos, todavia o estabelecimento dos limites entre o consumo recreativo e o uso contínuo até a dependência é o grande desafio de enfrentamento do consumo da bebida alcoólica (ALCHIERI, et. al., 2013:6).

O primeiro conceito de alcoolismo como doença, proposto inicialmente por Jellinek (1940), considera a estreita relação do processo de alcoolização com o adoecimento, propondo uma categorização de seus portadores de acordo com uma tipologia empiria que classificava os pacientes em função do consumo de álcool em Alfa, Beta, Gama, Delta e Epsilon (MARQUES, 2001 apud EDWARD, 1992). 
De acordo com Costa et. al. (2004), o relato da frequência da quantidade e dos tipos de bebidas alcoólicas consumidas semanalmente aponta para uma maior prevalência de fatores associados ao consumo abusivo de álcool, realçando uma alta probabilidade de morbidades relacionadas ao uso dessa substância. Entre essas morbidades, os autores destacam as limitações funcionais, a cirrose; alguns tipos de câncer Acidente Vascular Cerebral (AVC); violência das mais diversas ordens e transtornos mentais. Os autores constataram uma tendência linear de aumento de prevalência conforme a redução da escolaridade e da classe social juntada ao uso concomitante do cigarro (tabagismo).

Essas constatações aproximam-se dos resultados encontrados por Cardoso et. al. (2015:810) em suas pesquisas que indicam uma prevalência de abuso da bebida alcoólica entre pessoas do sexo masculino, cor da pele negra ou parda, não casada, sem religião e tabagista. Essas pesquisas revelam que os homens de pele preta ou parda, tabagistas, com baixo nível socioeconômico e com doenças crônicas associadas ao uso e abuso da bebida alcoólica são os grupos com maior consumo abusivo do álcool e, portanto, mais suscetíveis à morbimortalidade relacionada ao consumo desta substância (CARDOSO et. al. 2015). Dentre os fatores associados a esse consumo, os autores destacam: indivíduo do sexo masculino, escolarizados, fumantes, vítima de acidentes de trânsito e vítima de violência física/agressão física. Cabe esclarecer que essa prevalência de abuso da bebida alcoólica, por exemplo, entre a população negra está associada ainda a diversos outros fatores, como, por exemplo, ao baixo nível socioeconômico que indica uma maior vulnerabilidade social dessa população em uma sociedade capitalista com herança escravista.

O consumo nocivo de álcool é responsável, então, por cerca de 3\% de todas as mortes que ocorrem no planeta, incluindo desde cirrose a câncer hepático, acidentes, quedas, intoxicações e homicídios (MELONI E LARANJEIRA, 2004). No Brasil, e em outros países em desenvolvimento,

as bebidas alcoólicas são um dos principais fatores de doença e mortalidade, com seu impacto deletério sendo considerado entre $8 \%$ e 14,9\% do total de problemas de saúde dessas nações (LARANJEIRA; PINSKY \& ZALESKI, 2007 apud WORLD HEALTH REPORT, 2002).

Nesse sentido, o consumo abusivo da bebida alcoólica, nas mais diversas sociedades, desdobra-se para um quadro de agravos indesejáveis e muito onerosos no que tange às 
despesas públicas e ao desgaste de seus cuidadores, sendo a prevenção ou tratamento as medidas mais plausíveis neste contexto (BRASIL, 2003). Neves (2004:7) assevera que a Síndrome de Dependência Alcoólica "constitui-se como um problema a partir da confluência dos desdobramentos biológicos, psicológicos e sociais". A análise do uso patológico das bebidas alcoólicas, conforme a autora necessita de uma robustez maior, o que exige investimentos exegéticos e reflexões metodológicas sistemáticas, de modo a ser construído como objeto sociológico.

Na área de educação em saúde, o estudo de Pinsky e Jundi (2008:369) destaca o modo como a publicidade e a propaganda assumem um papel estimulador e eficaz no contexto do consumo de álcool. Os autores mencionam que os fatores de exposição à mídia (publicidade), bem como a atratividade da publicidade das bebidas alcoólicas, estão diretamente relacionados a uma maior expectativa de consumo no futuro, maior e mais precoce, entre adolescentes e adultos jovens. Eles revelam o papel da publicidade como "meio atrativo aprazível e de bem-estar, traduzido sinteticamente por elementos estimuladores da beleza, da força, da saúde e do sexo". E, por isso, outro aspecto relacionado à preponderância do abuso de álcool em povos indígenas é a maior integração com a sociedade ocidental bombardeada por campanhas publicitárias apelativas.

Conforme Pinsky e Jundi (2008:370), os meios acionam as "memórias afetivas positivas de liberdade e tomada de decisão, que são centrais para o imaginário coletivo por meio de efeitos neurocomportamentais", e, consequentemente, influenciam no hábito de se beber pelo valor social que a bebida potencializa de inserção na sociedade. Como esclarece Neves (2004:09),

mesmo que a ingestão de bebidas alcoólica seja valorizada para alcançar ou alterar estados de consciência e de expressão de sentimentos, essa transição prescrita deve ocorrer em contextos especiais, geralmente associados à ingestão de alimentos e à facilitação de atividades interpessoais, portanto, administrada pela situação coletiva. Por isso, é importante distinguir e contextualizar os significados dos termos culturais que demarcam as distinções: alcoolização, embriaguez, alcoolismo, bebedor, bêbado, embriagado, alcoólatra, alcoólico, alcoolista, alcoólico ativo. Eles dizem respeito aos graus de tolerância e às atitudes de cada um destes diferentes estados. Em várias sociedades não é o álcool que é condenado, mas o comportamento desviante dos indivíduos. Em consequência, há uma recorrente de valorização do homem que sabe beber sem se alcoolizar e sem interferir no desempenho de papéis a ele atribuídos. 
A esse respeito, o estudo de Laranjeira, Pinsky e Zaleski (2007:) indica que é na quantidade de doses tomadas em um único dia que o beber como lazer (o consumo) pode transformar-se em uso nocivo do álcool (abuso), com danos para a saúde que vão desde "a desinibição comportamental, comprometimento cognitivo, diminuição da atenção, piora da capacidade de julgamento" até a "diminuição da coordenação motora, entre outras". Pechansky et. al. (2004) enfatiza que a idade de início do uso de álcool e o padrão de consumo têm se tornando cada vez mais precoces em nossa sociedade, com a média de idade para o primeiro consumo de álcool aos 12,5 anos. Entre os fatores estimuladores para esse consumo precoce, conforme Vieira (2007) destacam-se principalmente o contexto familiar e o social.

Bastos et. al. (2004), por sua vez, identificaram que a bebida alcoólica é a substância mais frequentemente utilizada, quando comparada com outras drogas licitas e ilícitas, no cotidiano das pessoas que se auto declararam negras e indígenas em sua pesquisa. Seu estudo apontou, ainda, a predominância de consumo maior entre os homens $(13,2 \%)$ do que entre as mulheres (5\%), bem como o destaque para o fato do uso regular do álcool em indivíduos que não foram criados em lares em que a religião desempenhava papel relevante. Os autores ressaltam no estudo que vítimas de abuso sexual revelam-se mais propensas a consumir bebidas alcoólicas de forma regular. Outro fator preponderante apontado por eles para um maior consumo da substância alcoólica é a idade dos indivíduos.

Laranjeira e Romano (2004) fortalecem o primor nefasto que a bebida alcoólica é capaz de produzir no organismo humano, na perspectiva biopsicossocial, ao destacar as ações das substâncias alcoólicas e seus mecanismos de interação sob 3 (três) aspectos: (a) toxicidade direta e indireta, (b) a intoxicação aguda e (c) dependência.

Outra consequência grave do consumo da bebida alcoólica, apontada por Cardoso (2008), é a relação estreita de contaminação pelo vírus HIV. Os autores explicam que a

associação da desinibição e a crença do poder juntamente com a imunidade que a bebida alcoólica proporciona, podendo aumentar o prazer sexual, favorece a diminuição da capacidade de discernir os riscos associados ao sexo seguro, em outras palavras, favorece o comportamento de risco, facilitando assim, a gravidez na adolescência, a disseminação do vírus HIV e das Doenças Sexualmente Transmissíveis (DST's) (CARDOSO ET. AL., 2008: 72). 
A figura abaixo, extraída do artigo de Laranjeira e Romano (2004:69), esquematiza as possíveis ligações entre Padrões de Consumo e Volume Consumido a partir de 2 (dois) elementos centrais: Padrões de Consumo e Volume consumido.

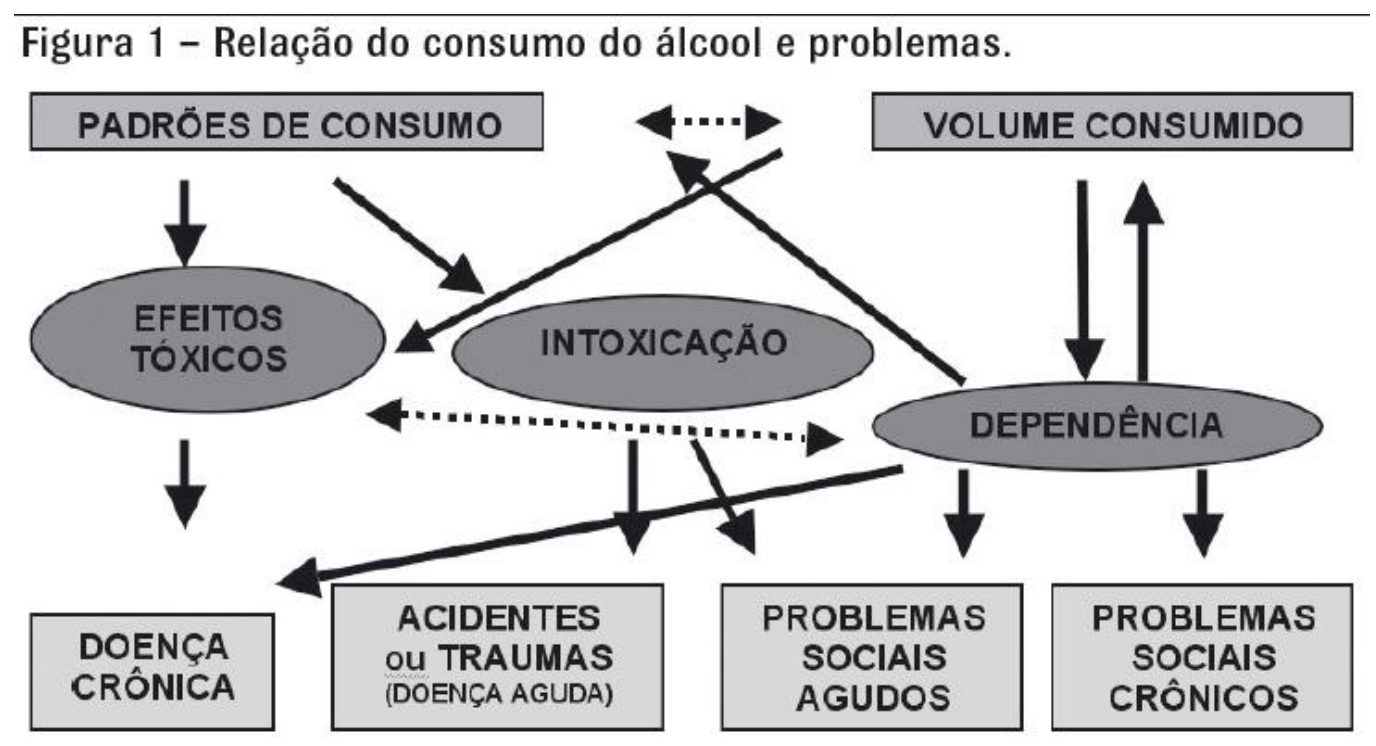

Fonte: Laranjeira e Romano (2004:69).

Entretanto, o estudo de Moretti-Pires e Corradi-Webster (2011) aponta que, no Brasil, estima-se que a média de álcool puro consumido por ano é de 8,6 litros per capita. Entretanto, considerando que existe um amplo número de bebidas alcoólicas produzidas artesanalmente sem controle governamental, pode-se inferir que essa média seja ainda maior. Segundo os resultados do II Levantamento Domiciliar Sobre o Uso de Drogas Psicotrópicas no Brasil, realizado nas 108 Maiores Cidades do País em 2005, cerca de 12,3\% da população brasileira apresenta dependência do álcool - o que em números absolutos corresponde a 5.799.005 de brasileiros (CEBRID/UNIFESP, 2006).

Esse levantamento revelou um aumento do padrão de consumo da bebida alcoólica, de cerca de 74,6\%, se comparado com o mesmo estudo realizado em 2001 (68,7\%). Segundo os dados apresentados no levantamento, se compararmos com outros países, como, por exemplo, o Chile que apresentou uma porcentagem de $86,5 \%$ e, ainda, os EUA, 82,4\%, verifica-se que estamos num patamar inferior. Contudo, o intuito do estudo é demonstrar quão prejudicial é o uso abusivo da bebida alcoólica para a sociedade e para os serviços públicos de saúde. 
Logo, o cerne das estratégias de Saúde Pública no Brasil deve se desenvolver estratégias visando minimizar os custos e melhorar a expectativa de vida, bem como a qualidade de vida das pessoas (COSTA et. al. 2004; BASTOS et. al. 2004). Os quadros abaixo demonstram os números de óbitos por residência de acordo com o transtorno mental e o comportamento devido ao uso do álcool por Região do Brasil. Os quadros expõem ainda a gravidade do consumo abusivo dessa droga psicoativa bem como evidenciam a relação existente do consumo da bebida alcoólica entre a população geral e as indígenas (CEBRID/UNIFESP, 2006; BRASIL, 2013).

\section{Quadro 4 - Óbitos p/Residência segundo Região}

Causa - CID-BR-10: ... 058.1 Transtorno mental e comportamento devido uso álcool Período: 2011

\begin{tabular}{|l|r|}
\hline \multicolumn{1}{|c|}{ Região } & \multicolumn{2}{c|}{ Óbito por Residência } \\
\hline TOTAL & 7.335 \\
\hline Região Norte & 256 \\
\hline Região Nordeste & 2.502 \\
\hline Região Sudeste & 2.856 \\
\hline Região Sul & 1.118 \\
\hline Região Centro-Oeste & 603 \\
\hline
\end{tabular}

Fonte: MS/SVS/DASIS - Sistema de Informações sobre Mortalidade - SIM

Quadro 7 - Internações segundo Região

Procedimento: 0303170026 TRATAMENTO DA INTOXICACAO AGUDA EM USUARIOS DE ALCOOL E OUTRAS DROGAS, 0303170166 TRATAMENTO CLÍNICO DE TRANSTORNOS MENTAIS E COMPORTAMENTAIS DEVIDO AO USO DE ÁLCOOL.

Período: Fev/2014

\begin{tabular}{|l|r|}
\hline \multicolumn{1}{|c|}{ Região } & Internações \\
\hline TOTAL & 1.513 \\
\hline Região Norte & 35 \\
\hline Região Nordeste & 194 \\
\hline Região Sudeste & 390 \\
\hline Região Sul & 875 \\
\hline Região Centro-Oeste & 19 \\
\hline
\end{tabular}

Quadro 6 - Óbitos p/Residência segundo Capítulo CID-10

Causa - CID-BR-10: ... 058.1 Transtorno mental e comportamental devido uso álcool Cor/raça: Indígena 


\begin{tabular}{|c|c|}
\hline Ano & Óbito por Residência \\
\hline $1996-1999$ & 70 \\
\hline $2000-2005$ & 87 \\
\hline $2006-2011$ & 139 \\
\hline
\end{tabular}

Fonte: MS/SVS/DASIS - Sistema de Informações sobre Mortalidade - SIM

Para tratar dessa situação, abordar a temática do consumo, do uso, do abuso, da ingesta do álcool, entre outras categorias, o Ministério da Saúde (MS) desenvolveu a Política de Atenção Integral aos Usuários de Álcool e outras Drogas. O caderno temático dessa política Estratégias de enfrentamento acerca do uso e abuso do álcool e outras drogas - visa amortizar a lacuna ainda em aberto que advém da exiguidade dos cuidados integrais que atingem, de forma histórica e permanente, os cidadãos que padecem pela falta de oportunidade de cuidados integrais, particularmente os indivíduos contextualizados culturalmente bem como, aqueles discriminados socialmente (BRASIL, 2003).

A política do Ministério da Saúde (MS), entre outras estratégias postas em Portarias Ministeriais, realça elementos estruturantes e de grande valia para a eficácia e eficiência do tratamento, não apenas nos contextos biomédicos assistencialistas, mas em seus pressupostos bio-psico-social (compreensão psicológica, cultural, econômica, política e social acerca dos motivos primários do uso/abuso do álcool). Desse modo, essa política tem o intuito de assumir de modo integral e articulado o desafio de prevenir, tratar, reabilitar os usuários de álcool e outras drogas na perspectiva de problema de saúde pública (BRASIL, 2002).

É relevante ressaltar que na Política do MS, ao se referir a oportunidades de cuidados, observam-se dois elementos de destaque imprescindíveis e decisivos para a eficácia do tratamento de pessoas que sofrem da Síndrome de dependência da bebida alcoólica:

(a) A vontade lábil do usuário em procurar o cuidado/tratamento (mais precisamente, as singularidades de como, onde e porque tratar);

(b) A facilidade de acesso aos serviços para o efetivo tratamento. 
A Política Ministerial salienta de maneira imperativa a estruturação e o fortalecimento da rede de assistência centrada na atenção coletiva associada a uma rede de serviços de saúde e sociais que deem conta da reabilitação e da reinserção social dos seus usuários em seu núcleo de convívio - o chamado Centro de habilitação Psicossocial em Álcool e Drogas (CAP-AD).

À vista disso, o CAPS-AD deve obedecer a uma lógica de oferta de cuidados baseados na atenção integral, devendo ter como principais atributos:

a) Ofertar aos usuários de álcool e outras drogas e seus familiares, acolhimento, atenção integral (práticas terapêutico-preventivas/de promoção de saúde/educativas/de reabilitação psicossocial) e estímulo à sua integração social e familiar;

b) Inserção comunitária de práticas e serviços, os quais devem atender a uma população referida a um território específico.

Sobre a integração social, Vieira et. al. (2007) destacam que os padrões de comportamento aprendidos e mantidos pelos sujeitos nas suas experiências de vida são fatores cognitivos influenciados por modelos, expectativas e indicadores singulares. A essa perspectiva, Nathan (1983, apud PILLON \& VILLAR LUIS, 2004) aponta um significado do uso da bebida alcoólica para além da interação do comportamento do meio, incluindo fatores genéticos (contudo faltam estudos mais aprofundados para essa conceituação).

Dessa maneira, Menéndez (2013:) defende, assim como Pillon e Villar Luis (2004), a ideia de que

\begin{abstract}
o álcool é, em determinados contextos, uma forma cultural como um conjunto de apetrechos e mecanismos, aparentemente imprescindível para a concretização de relações e rituais sociais. Portanto, o seu consumo não está vinculado apenas a efeitos negativos. Por isso, o autor pondera que o consumo da bebida alcoólica cumpre, em diferentes grupos étnicos, funções psicotrópicas, terapêuticas, alimentares, de sociabilidade familiar, além de auxiliar o controle social, a exploração econômica, as justificativas racistas, ou de legitimação de atos de violências. Sendo este consumo social ou isolado.
\end{abstract}

Considerando os diversos elementos singulares e as mais diversas formas de concepções do uso e abuso do álcool, Pillon e Villar Luís (2004:676) destacam que o uso das substâncias e as mais diversas formas do comportamento humano são questões complexas que 
requerem enfoque ampliado e simplificado: entender o caso no seu foco de inserção, bem como propor atendimento singular aplicado às causas oriundas de suas peculiaridades.

Para tanto, os autores apresentam alguns modelos de intervenções e tratamentos com base nas diversas concepções e motivos que promovam o uso e abuso, entre eles, as “características específicas da personalidade individual; a falta de maturidade, os conflitos intrapessoais e interpessoais; a baixa autoestima, ou problemas psiquiátricos como depressão ou transtorno de ansiedade, entre outros" (ibidem, 2004:678):

(a) Modelo Ético Legal: de acordo com este modelo, o enfoque se dá nas consequências dos atos "antissociais" e "imorais" destoantes do padrão social coletivo, Estes indivíduos transgressores, que se escondem por de trás do uso e abuso da bebida alcoólica para justificar seus atos inconsequentes, devam sofrer a intervenção preventiva apoiada nas medidas disciplinares de caráter positivista e punitiva acionados pelos sistemas legislativo, judicial e policial;

(b) Modelo Moral: este está centrado na conscientização de seus atos, como responsáveis e co-responsáveis. Propõe-se como soluções de intervenção a motivação apropriada.

(c) Modelo Médico ou de Doença: este modelo está centrado na relação da "dependência de substâncias psicoativas" e do "tratamento médico". Em que o vício o qual é visto como um problema caracteristicamente sintomático e de perspectiva clínica.

(d) Modelo Psicológico ou Psicossocial: esse modelo parte do pressuposto do "aprendizado social, a interação familiar e os traços da personalidade do indivíduo ". Ele propõe o modelo de replicar comportamental, particularmente dos modelos intrassociais. O que as autoras defendem é que "o modelo de aprendizado social propõe que o comportamento social é aprendido através da observação e imitação".

(e) Modelo Sociológico ou Sociocultural: nesse modelo a inicialização do consumo da bebida alcoólica é considerada como consequências de fatores sociais e culturais que envolvem crenças, valores e atitudes em sociedades e grupos específicos que defendem como correto a interação entre o uso do álcool e a vida. É considerado pelas autoras como um "modelo ambientalista", pois destaca o ambiente na conduta do indivíduo; em sua interação com os elementos sociológicos (do grupo ou subcultura à qual ele pertence) bem como nas nuances culturais (costumes e tradições). 


\subsection{O USO E O ABUSO DE ÁlCOOL ENTRE OS POVOS INDÍGENAS}

\section{BRASILEIROS.}

A Antropologia Médica, que era como Uchôa e Vidal (1994:497) tratavam a, hoje intitulada, Antropologia da Saúde, apresenta, segundo esses autores, reflexões importantes para se compreender o uso e o abuso do álcool entre os povos indígenas, visando evidenciar a importância do discurso antropológico na abordagem da saúde e da doença com o intuito de dialogar com noções básicas de saúde e de doença nos mais diversos fenômenos; e com suas amplas complexidades que conjugam fatores biológicos, sociológicos, econômicos, ambientais e culturais. De acordo com os autores, a complexidade do objeto saúde e doença, doença e feitiçaria, desassistência e práticas ritualísticas locais, no campo da saúde indígena, revela-se na multiplicação de discursos sobre a saúde que coexistem atualmente, cada um privilegiando diferentes fatores e sugerindo estratégias de intervenção e de pesquisa também diversas. Para eles o discurso antropológico

aponta os limites e a (in)suficiência da tecnologia biomédica quando se trata de mudar de forma permanente o estado de saúde de uma população. Ele nos revela que o estado de saúde de uma população é associado ao seu modo de vida e ao seu universo social e cultural. A antropologia médica se inscreve, assim, numa relação de complementaridade com a epidemiologia e com a sociologia da saúde (UCHÔA e VIDAL, 1994:497).

Segundo Nichter (1989 apud UCHÔA e VIDAL, 1994:498), na sociologia da saúde, “os problemas são apreendidos em sua dimensão social e não individual”. Esse campo do saber, segundo os autores, investiga a determinação que exercem os contextos social e institucional sobre as enfermidades e os comportamentos delas decorrentes; considerando a saúde e o que se relaciona a ela, seus riscos, suas maneiras de prevenção, as noções de causalidade, as ideias e o conhecimento sobre o risco e os tratamentos como fenômenos culturalmente construídos e interpretados.

$\mathrm{Na}$ tentativa de contribuir para ampliar o contexto que deve ser levado em consideração na leitura dos processos patológicos, Neves (2004) discorre acerca do multiprofissionalismo engajado no apoio, resgate e tratamento a todos que, de certa forma, se envolvem com a temática do uso e abuso do álcool entre povos indígenas. O autor propõe 
"uma recostura da estrutura mental e sequencial de conduções temáticas para dar conta dos efeitos benéficos e dos efeitos nefastos que o Processo de Alcoolização acarreta para o indivíduo e, consequentemente, para o coletivo" (NEVES, 2004:9-10).

Assim, para compreender os processos de beber das comunidades indígenas, de maneira particular, é fundamental ter clareza acerca dos "fenômenos dos diversos usos e abusos da ingestão; e, para isso, é preciso deslocar o problema do campo físico-individual para o coletivo-social" (LANGDON, 2013:34). Nesse sentido, os indivíduos necessitam ser abordados numa contextualização múltipla, dinâmica e social (LAPLANTINE, 2007) para não "apenas ficar nos porquês do consumo tomando como objeto de estudo o Processo de Alcoolização" (NEVES, 2004:11).

O estudo de Silveira et. al. (2011), trás uma revisão sistemática da literatura sobre estigma social e alcoolismo, sugerindo uma reflexão interessante ao resgatar as diversas formas de estigmatização do ato de beber. Essas reflexões possibilitam diversos significados e maneiras do ato de beber. Os pesquisadores mencionam, especialmente em relação à percepção dos profisssionais de saúde, a falta de treinamento específico desses profissionais já que os elementos conceituais ou até mesmo práticos para lidar com a temática do álcool são escassos ou até mesmo subjetivos. Essa falta de treinamento específico pode, portanto, desencadear um olhar condenador sobre quem faz uso ou o abuso da bebida alcoólica. Nesse sentido, as possíveis consequências de determinadas representações sociais dos profissionais de saúde indígena, no que tange ao uso e abuso da bebida alcoólica, podem ser em determinados povos muito mais danosas do que as próprias consequências do uso elou abuso da bebida alcoólica.

A esse respeito, Goffman (2008:25) assegura que o "sujeito ativo quando encara um indivíduo que desempenha um papel na sociedade, implicitamente solicita de seus observadores que levem a sério a impressão sustentada perante eles”. Essas representações podem levar, por exemplo, os profissionais de saúde indígena a crer, como também pontua Goffman, que "o personagem que veem no momento possui os atributos que aparenta possuir, o papel que representa terá consequências, implicitantes, predeterminantes”. Em outras palavras, pode "ser sinceramente convencido de que a impressão de realidade que encena é a verdade e é a realidade". 
Consoante Neves (2004) é fundamental valorizar empiricamente as situações de produção da ilegitimidade do consumo da bebida alcoólica, destacando que são as atitudes que constituem fatos a serem explicados e, porquanto, não se podem ser tomadas como explicações generalizadas. A questão a ser investigada se desloca então para a compreensão do modo como os membros de segmentos sociais e culturais específicos se relacionam com a embriaguez (NEVES, 2004:11). Em consonância, Uchôa e Vital (1994:500) argumentam que é necessário, então, superar a visão reducionista dos fenômenos saúde e doença, encarando essa como fenômeno multidimensional. Ou seja, não apenas como um problema físico\mental ou biológicolpsicossocial já que a fragmentação do objeto gera a fragmentação das abordagens, o que retarda a apreensão multidimensional do objeto.

Partindo da noção de doença como um problema físico ou mental, Coimbra (2003) salienta que o consumo da bebida alcoólica entre os índios desencadeia doenças tidas como doenças crônicas degenerativas bem como as doenças sociais, a de exemplos semelhantes a da população não índia, cirrose, diabetes, hipertensão arterial, doenças do coração, do aparelho digestivo, depressão e estresse. $\mathrm{O}$ autor acrescenta, ainda, que pode propiciar fatores externos como acidentes, brigas, quedas, atropelamentos, entre outros. Não obstante, Coimbra (2003) destaca o outro lado da moeda, ou melhor, do outro lado do "gole" em que se observa, particularmente, o uso e até mesmo o abuso como parte de ritos, crenças e culturas.

Langdon (2001:85), enfatizando a importância da apreensão do significado do beber ${ }^{1}$ para as múltiplas culturas e sociedades, particularmente tratando-se dos povos indígenas já estudados, alega que o consumo da bebida alcoólica pode estar associado a um ritual de liberação das inibições o qual leva a pessoa para outro estado de ânimo em sua sociedade.

\footnotetext{
${ }^{1} \mathrm{O}$ autor cita como exemplo, o caso da Festa de Kiki, realizada pelos índios Kaingáng, no sul do Brasil, e conhecida localmente como a farra dos índios (...) até o início do século, parece que este rito em homenagem aos mortos foi realizado por todas as aldeias Kaingáng Hoje em dia, os Kaingáng de Xapecó ainda mantêm este rito como a afirmação simbólica de sua identidade étnica, sua organização social e das relações recíprocas entre os vivos e os mortos e entre as duas metades da sociedade. O rito liga o grupo com o ciclo anual da natureza, sua mitologia, e as mortes que aconteceram no período desde o último Kiki. Ela é marcada por vários momentos ritualísticos: tombar-se a arvore do pinhão e fazer a cocho; preparar a bebida kiki feita tradicionalmente com mel para sua fermentação na cocha; e realizar três noites de fogo finalizando com uma viagem ao cemitério na qual cada metade do grupo rezam sobre os túmulos dos mortos da outra metade. Na volta, a concha, que estava coberta durante várias semanas para fermentação, é aberta e a comunidade festeja até que termina a bebida. Todas estas atividades são organizadas por grupos de parentesco, divididos em duas metades, Kame e Kairu, cada uma com suas responsabilidades organizadas numa maneira recíproca. A metade Kame complementa e realiza atividades para a Kairu (LANGDON, 2001:85-86).
} 
Desse modo, em busca da apreensão do significado do beber para povos indígenas, refletiremos sobre os resultados dos textos da série Processo de Alcoolização Indígena no Brasil: perspectivas plurais, organizado por Souza (2013), que aborda a temática sobre o processo de alcoolização entre os diversos povos indígenas do Brasil a partir de uma contextualização múltipla, dinâmica e social.

Segundo Menéndez (2013), pensar no álcool como conceito apenas biomédico, é desconsiderar as investigações antropológicas cujos consumos estão inseridos nos mais diversos enfoques, oferecendo, de certa forma, um limitar de danos. O autor enfatiza que, de fato, o "álcool, alcoolismo e processo de alcoolização são conceitos estreitamente relacionados, mas não intercambiáveis, tendo em vista a diferenciação e a contextualização desses conceitos" (MENÉNDEZ, 2013: 11-12). Ele destaca que os

homicídios, as agressões intrafamiliares, a desnutrição entre as crianças e os acidentes não são consequências necessariamente advindas do uso da substância alcoólica; entretanto, esse uso seja provido de um comportamento considerando estimulador, aceito pelas mais diferentes sociedade e pelos sujeitos específicos nelas inseridos (MENÉNDEZ, 2013:12).

À vista disso, Menéndez (2013) enfatiza que são as condições e não os atos de ingestão que possibilitam compreender a agressividade ou a estigmatização no âmbito individual e/ou coletivo de se beber; de modo que não é o caso de se negar o papel do sujeito, mas sim alertar para a necessidade de pensá-lo em articulações dentro do processo sociocultural, político e econômico. Nessa perspectiva, o processo de alcoolização é tido como

\footnotetext{
um conjunto de funções e consequências positivas e negativas que cumpre a ingesta de álcool para conjuntos sociais estratificados e não apenas o estudo dos alcoólicos dependentes, nem os excessivos, em os moderados, nem os abstêmios, mas sim o processo que inclui a todos e que evita considerar o problema em termos de saúde e/ou enfermidade mental. (MENÈNDEZ, 1982:63)
}

E, por isso, é fundamental construir uma interlocução de saberes necessários para compreender as múltiplas facetas do consumo da bebida alcoólica entre grupos culturalmente distintos, reconhecendo o ato de beber como uma condição social embebido no contexto de valores, atitudes, normas, modos de classificação do tempo e concepções do real para cada grupo (NEVES, 2004). 
Considerando esses contextos, Langdon (2013) descreve que o uso abusivo da bebida alcoólica é concebido como algo complexo, resultante de vários fatores socioculturais que determinam vários comportamentos relacionados à ingesta destas substâncias, bem como a criação dos estereótipos, sendo talvez o mais atroz de todos. Das representações sociais construídas nesse processo, a autora destaca a imagem do "índio bêbado como uma das mais atrozes, convalidado na afirmação válida e particular dos brancos que vivem perto de áreas indígenas" (LANGDON, 2013). Essa imagem negativa, juntamente com outras semelhantes que o brasileiro tem do índio, tais como indivíduo sujo, ignorante e preguiçoso, expressa, para a autora, a representação estigmatizada que é experimentada frequentemente pelos índios quando interagem com a sociedade não índia.

Diante desse quadro, o estudo sobre o processo de alcoolização entre os povos indígenas não é um precedente exclusivo do Brasil, já que se trata de um desafio de alta relevância para todos os sistemas de saúde públicos por estar impregnado de violência social, suicídio, precariedade nas condições de saúde e como facilitador de comportamentos de risco para DST/AIDS, entre outros (LANGDON, 2013).

Assim, diante do peso do preconceito associado ao termo alcoolismo de um lado e dada a sua imprecisão conceitual de outro lado, Souza e Garnelo (2006) destacam que esse termo foi abolido do cenário biomédico. Por conseguinte, os autores apresentam a substituição por um novo termo, a Síndrome de dependência do álcool, que dê conta de contemplar aquilo que se pretende dentro do campo da Saúde Pública e das Ciências Sociais. Esse novo termo, trazido pelo Código Internacional das Doenças (CID 10), trás no seu bojo uma série de desdobramentos como F10 - Transtornos mentais e comportamentais devidos ao uso de álcool.

Esse novo termo é mais abrangente por se tratar de um fenômeno unitário ou divergente e que não há cura, o que auxilia na promoção de definição de diversos modelos de tratamento, porque se o consumo da bebida alcoólica "é um fenômeno heterogêneo, para as ciências sociais torna-se imprescindível entender as particularidades que circundam o abuso dentro do caráter particular e sociocultural" (SOUZA \& GARNELO, 2006: 282). Logo, por possuir um caráter particular e sociocultural, existem diversas evidências que, segundo os autores, sustentam a ideia de que fatores sociais e culturais relacionados ao consumo da bebida alcoólica "regulam a forma pela qual as pessoas fazem uso desta substância e, ainda, 
contribuem para a variação dos problemas relacionados ao uso de álcool entre diferentes grupos, principalmente os minoritários" (SOUZA \& GARNELO, 2006: 282).

Os autores, ainda, destacam que um primeiro ponto é o fato de existirem culturas que estimulam a abstinência do uso de álcool, e outras que são permissivas. Citam como exemplos o consumo da bebida alcoólica nas culturas mulçumanas em que a influência sobre o beber é explicitamente negativa, proibitiva dependendo da região e da postura mais tradicional. Já nos países do mediterrâneo, o beber é ativamente apoiado, sendo alta, nesses países, a prevalência de problemas clínicos associados ao beber (VAILLANT, 1999 apud SOUZA \& GARNELO, 2006:282 - 283).

Outros estudos também demonstram que o processo de alcoolização varia entre grupos, indicando que não há uma causa única universal para o abuso destas substâncias, bem como as explicações para a variabilidade no consumo das várias substâncias alcoólicas, que, por sua vez, são singulares (LANGDON, 2013). Citando os estudos de Kunitz e Levy (1994), a autora destaca o caso dos índios Navajos dos Estados Unidos (entre 1960 e 1990), por exemplo, que revela o consumo social de uma grande quantidade de bebida alcoólica, porém, entre os grupos masculinos. Esse consumo, segundo a autora, poderia durar horas ou dias, até os seus usuários caírem. Todavia, entre os episódios de uso abusivo, existiam aqueles que consumiam a bebida de maneira solitária, isolada.

A distinção, segundo o estudo realizado, foi que entre beber socialmente e de maneira individual demonstrou-se, com o passar dos anos, que neste grupo os indivíduos que bebiam coletivamente paravam espontaneamente sem nenhum tratamento. Já os indivíduos que bebiam de maneira solitária, tinham dificuldades de regular o seu consumo e acabavam padecendo, mais frequentemente, por causas relacionadas ao abuso da substância, pois existia um comportamento social fim, que conduzia o grupo a consumirem coletivamente, diferentemente dos solitários (KUNITZ \& LEVY, 1994 apud LANGDON, 2013).

Um outro estudo realizado com povos indígenas por Quiles (2013:65), os Bororo do Estado do Mato Grosso-MT, demonstra "um sério problema de ordem do abuso generalizado pelo consumo da bebida alcoólica, a partir de relatos do consumo de álcool de farmácia e até mesmo álcool de carro, no temperado meio a meio com açúcar e limão, e, mais tarde, puro”. O autor menciona que, por tempos, a sociedade conspirou para uma menção de silêncio total diante desta realidade caótica, que, de certo modo, estava desvelado por todo mundo, 
influenciadas por um purismo dadas às prerrogativas tradicionais como a de que o "índio bebe mesmo", ou, até mesmo, pela falta de instrumentos teóricos adequados para uma intervenção assertiva e adaptada neste padrão cultural e interético.

Para o pesquisador, o gosto e o costume em consumir o álcool são difusos entre homens, mulheres, velhos e jovens, observando que ora bebiam em épocas sazonais ou eram manifestamente dependentes no período integral, destacando apenas uma minoria que se abstiam, relatando com muito esforço esta negativa de consumo. Porém, sempre "motivado pelo padrão de ingesta socializada, grupal e, decorrente disto, incentivado pela pressão grupal para o consumo, ou seja, reforçado pela alcoolização coletiva" (QUILES, 2013).

Berger e Luckman (1974 apud QUILES, 2013) afirmam, sem receio, que o consumo do álcool entre o povo indígena Bororo se deu a partir da conformação cultural com a iniciação dos jovens por parte dos mais velhos, e com brincadeiras entre crianças imitando os adultos, quesitos necessários para a socialização de qualquer nova instituição. A pesquisa de Quiles (2013) “mostra que o comportamento e o hábito de beber álcool entre o povo Bororo não segue os mesmos padrões da população não indígena”. Os Bororos bebem intermitentemente, todavia, até mesmo os mais crônicos, passam longos períodos sem beber, fato este que deveria disparar uma "Síndrome de Abstinência", classificada no CID 10 como F10.3 (Transtornos mentais e comportamentais devidos ao uso de álcool - síndrome (estado) de abstinência ou até como F10.4 - Transtornos mentais e comportamentais devidos ao uso de álcool - síndrome de abstinência com delirium).

A explicação dessa diferença no padrão de dependência está, cogita o autor, para além de fatores genéticos e metabólico-enzimáticos não pesquisados entre o Povo Bororo, numa razão plausível de que eles tiveram pouco acesso à bebida destilada, por motivos econômicos e pela distância dos locais de fornecimento, fazendo uso da bebida tradicional o iwóro, bebida fermentada à base de palmito de acuri, que requer vários dias para se obter em quantidades consideráveis (ibidem, 2013:67).

Outro ponto de destaque na pesquisa de Quiles (2013) são os efeitos da substância alcoólica entre o povo Bororo, como, por exemplo, a função que o álcool exerce no imaginário como um fator que leva a recuperação das forças como ponto de energia para o ataque ou vingança. Foram os inúmeros relatos obtidos pelo autor em sua pesquisa que diziam “o Bororo bebe para ganhar força", pois a expressão falta de coragem abrange tudo o que 
queremos dar a entender como a repressão de toda a agressividade (ibidem, 2013:77). Por isso, a expressão trazida por Langdon (2001:86) "a maneira de beber, como beber e quanto beber nas culturas indígenas têm sido definido por cada etnia específica”, e o consumo de bebidas fermentadas é "uma manifestação das atividades constitutivas para o grupo social, expressando sensações e valores particulares”.

Como exemplo do consumo de bebidas fermentadas enquanto manifestação das atividades constitutivas para o grupo social que expressa sensações e valores particulares, Souza e Garnelo (2013), ao estudarem os índios do Alto Rio Negro, representados pelos Tukáno, Aruák e Makú, pertencentes ao mesmo tronco linguístico, identificaram que a representação do uso da bebida alcoólica está diretamente ligada à cosmologia da origem do mundo (deuses primordiais) no que se refere ao consumo do caxiri - bebida alcoólica fermentada, preparada com beijus e uma variedade de mandiocas. Seu modo de preparo necessita da fermentação do biju e da mandioca que são colocados em recipientes de barro, juntamente com batatas, geralmente com cor roxa, e cana-de-açúcar, onde passam alguns dias fermentando (DIAS, 2013:122). Esse processo é visto como uma cerimônia realizada de forma coletiva, em que os laços de solidariedade e obrigações são mútuos. As festas cerimoniais, por sua vez, perpetuam durantes dias ou até o caxiri se esgotar.

Entretanto, com o contato interétnico pelos colonizadores, foi introduzida a cachaça, recebida satisfatoriamente pelo Povo do Alto Rio Negro, bem como outras substâncias, como o álcool de farmácia, desodorantes e perfumes. Esse povo passou a utilizar essas substâncias como consumo regular, mudando, assim, a "maneira e os motivos de se beber" (LANGDON, 2001; SOUZA \& GARNELO, 2013). Como exemplo das mudanças no comportamento dos indígenas ocorridas pelo contato interétnico, os autores destacam ainda a introdução da educação formal pelos missionários.

Com a instalação de algumas instituições em seu local de convívio, consequentemente, acarretaram algumas mudanças importantes na organização dessas sociedades indígenas, tais como a concentração das famílias em locais próximos às aldeias com escolas e postos de saúde. Tal mudança parece se associar, de acordo com os autores, ao aumento das situações em que se bebe; uma vez que o álcool consumido gera uma maior mobilização coletiva, em contraste com as tradicionais relações de hierarquia que ancestralmente regem o ethos rionegrino. 
O consumo da "cachaça entre os povos indígenas foi tão devastador que em pouco tempo tornou-se a bebida destilada mais consumida no Brasil, e a terceira no mundo, entre quases todos os Povos Indígenas" (BOGUSZ JUNIOR et. al., 2006:). Sobre esse consumo, Auguste de Saint-Hilaire (1937), em "Viagens pelas Províncias do Rio de Janeiro e Minas Gerais" (1817), registrou uma apetência geral pela aguardente, incluindo os brancos, as mulheres, os índios e os negros. Em seus relatos, ficou evidente o sestro (por vezes, desastroso) desses dois últimos indivíduos - índio e os negros - pela bebida (PINHEIRO, LEAL \& ARAUJO, 2003, apud ZERON, 2000: 59).

Para Monteiro (1995:223), um dos motivos que justifica o interesse de se estudar grupos socialmente ignorados como, por exemplo, os povos indígenas é a possibilidade de desaparecimento desses povos devido ao chamado processo "civilizatório" que gerou o deslocamento desses povos paras as áreas urbanas; a imposição de sistemas de trabalho que desagregam as comunidades; a assimilação forçada; a descaracterização étnica; e, certos casos, até a violência premeditada e o extermínio físico.

Mesmo diante desses aspectos negativos, na percepção desse autor, nos últimos anos no Brasil, a história indígena contada é bastante positiva tendo em vista que os índios passaram a atuar como sujeitos críticos que se posicionam politicamente frente aos problemas das mais diversas ordens enfrentados por suas comunidades, organizando-se por meio de organizações para reivindicar direitos, como, por exemplo, serviços de saúde que respeitem e atendam as suas necessidades.

Os resultados dessas pesquisas com diferentes povos indígenas reforçam os estudos de Aureliano e Machado Jr. (2012:63) cuja tese aponta reflexões sobre o fato de que: (a) o conceito de alcoolismo não é restrito ao campo das ciências da saúde, uma vez que esse fenômeno possui características que perpassam outros elementos explicativos; (b) a compreensão participativa é tida como uma prática que não só pode auxiliar para o seu melhor entendimento como tem um grande potencial de levar as intervenções a êxito, pois produz empoderamento aos próprios indígenas, tornando-os agentes ativos do processo; (c) a violência é ponto comum e muito recorrente nos textos.

A relação do alcoolismo esta diretamente ligado à questões de violência doméstica, acidentes, suicídio e práticas sexuais fora dos padrões culturais; (d) problema de saúde pública - os trabalhos indicam que o alcoolismo é um problema de saúde endêmico 
demandando ação planejada e intencional do poder público competente; (e) a coletividade - o consumo de bebidas destiladas no contexto indígena do Brasil é feito em grupo. Esse deve ser um princípio norteador para as ações de intervenção que necessitam valorizar as atividades que envolvem a coletividade.

Um estudo com o povo indígena Iauaretê, localizados no distrito rural do município de São Gabriel da Cachoeira, às margens do rio Uaupés, considerado o maior afluente do rio Negro, mostra que o consumo e abuso da bebida alcoólica tem sido cada vez mais precoce entre os jovens indígenas. Segundo Souza, Deslandes e Garnelo (2013:), os Iauaretê "tendem a degustar mais precocemente a bebida alcoólica se comparados a outros povos indígenas, faixa etária de iniciação entre 12 a 13 anos". Eles esclarecem que essa faixa etária está relacionada com um fator sociocultural que tem a ver com o modo do consumo da bebida, que é acompanhado por problemas de ordem sociocultural, entre eles, a violência. O que dificulta, assim, ações coletivas de enfrentamento. Uma maior capacidade de ingesta alcoólica e a capacidade física de dançar por horas são indicativos para se tornarem membro do grupo, legitimando, desse modo, a obtenção de permissão para buscarem duas parceiras sexuais, para então estreitarem as relações de matrimônio.

Koifman (2001:414) mapeou os principais impactos sócio-econômicos da atualidade, frente ao crescimento desenfreado dos processos e progressos econômicos, apontando a construção de usinas hidrelétricas como um dos fatores que mais causaram impactos negativos nas comunidade indígenas no Brasil, particularmente entre os Akwẽ-Xerente. $\mathrm{O}$ autor cita a realocação de comunidades para outras regiões devido às expansões da agroindústria, muitas vezes acompanhada da mudança de seus estilos de vida; a desapropriação de grandes parcelas territoriais ainda não demarcadas, frente ao crescimento das cidades; a diminuição da disponibilidade da caça e a redução das áreas cultiváveis.

Com relação ao ato de violência, Dias (2013:109) defende que as expectativas sociais e individuais em relação à bebida modelam as atitudes de quem bebe, além de darem forma as mais diversas justificativas e desculpas possíveis que decorrem dessas atitudes. Em ambientes em que o álcool encontra-se vinculado à violência, há, segundo o autor, uma grande tendência de se justificar condutas fora do padrão apelando-se para o fato de a pessoa agir sob efeito do álcool. Por sua vez, em contextos em que o álcool está revestido com "positividade", apelar para a bebida como desculpa para atitudes agressivas e violentas, esclarece o autor, "não só será inócuo, como intensificará a gravidade da ofensa". 
Dias (2013:109), que pesquisou o Povo Indígena do Uaçá, argumenta ainda que "o consumo da bebida alcoólica resgata de certa forma o alívio da pressão do coletivo sobre o indivíduo, já que a embriaguez induzida pelo álcool permite explorar experiências potencialmente perigosas". Esse temor, de acordo com o autor, é um estímulo para a reafirmação da

solidariedade que reforça os laços sociais da vida cotidiana. Se as representações individuais e coletivas acerca do álcool forem de agressividade, logo o recíproco das atitudes será semelhante, ou se a bebida favorece a desinibição, os resultados serão de mais espontaneidade (DIAS, 2013:108).

Para esse pesquisador, o consumo da bebida alcoólica entre esse povo indígena localizado no município de Oiapoque, no extremo norte do estado do Amapá, serve para definir o mundo social e seus simbolismos, pois "toda a bebida é um veículo simbólico que carrega uma mensagem que identifica, discrimina, constrói, destrói e manipula sistemas sociais, valores, relações sociais, normas e expectativas de comportamento" (DIAS, 2013:110). Sua hipótese se ancora na ambivalência: "se o consumo é positivo serve para aproximar e estreitar os entes familiares numa construção social harmoniosa, caso o inverso seja imperativo, o consumo se apresenta de forma a criar rupturas sociais" (DIAS, 2013:110). Ele ressalta que o bem beber e o consumo indesejável não estão ligados diretamente à quantidade da bebida ingerida, portanto a noção de excesso ganha sentido apenas se relacionado ao contexto específico no qual ocorre.

Segundo Aureliano e Machado Jr. (2012:54), que "o álcool passa a assumir um lugar na cultura indígena antes ocupado pelas bebidas tradicionais da sua cultura, por vezes substituindo-as completamente, em outras ocasiões convivendo paralelamente”. Essa mistura, contudo, expressou-se não apenas em termos físico-químicos, mas especialmente em termos culturais.

Outro estudo realizado sobre o consumo da bebida entre povos indígenas, por Acioli (2013) apontou três elementos de sentido para se entender de fato o uso e abuso da bebida alcoólica entre esse povo : (1) corresponde aos "modos tradicionais de consumo da bebida alcoólica como um momento de não produção econômica para muitos, seja nos fins de semana ou em ocasiões especiais"; (2) está ligado ao "processo migratório de viagens de idas e vindas para o sul do Brasil, como um alívio para as condições econômicas adversas da área 
indígena", mas desencadeador de sofrimento oriundo pelas doenças, entre elas, a Síndrome de Dependência de álcool e a própria morte; (3) "a fixação de pontos de venda clandestina de bebidas alcoólicas como uma estratégica ilegal de atividade econômica" o que representa 'fugir' da ordem legal.

O conjunto de estudos apresentados nessa revisão aponta à necessidade de se abordar a questão do uso e abuso de bebidas alcoólicas pelos povos indígenas primeiro por uma perspectiva antes coletiva que individual, depois por uma consideração das especificidades culturais de cada povo. A passagem abaixo do trabalho de Dias (2013) sintetiza bem essa abordagem assumida pela presente dissertação:

Privilegiar uma abordagem social e coletiva do consumo de bebida, ao invés de adotar uma visão em que foque o individuo, sendo parte resultante do caminhar para uma adequação a fim de compreender o modo do consumo no Uaçá, que por sua vez, é sustentado pela valorização do trabalho entre as famílias e entre os grupos, assim como para perceber que as interpretações indígenas do excesso indicam o seu poder ambivalente. Consumir muita bebida não diz se a atitude é moralmente aceita ou reprovável, bem como, ingerir bebidas alcoólicas imoderadamente pode ser culturalmente adequado ou inadequado, conclui-se que apenas os contextos específicos de consumo que podem definir as especificidades e por fim qualifica-los (DIAS, 2013:121).

\subsection{A POLÍTICA NACIONAL DE SAÚdE INDÍGENA E O SUBSISTEMA DE SAÚDE DIANTE DO PROBLEMA DO USO E ABUSO DE ÁlCOOL PELOS POVOS INDÍGENAS.}

A fim de minimizar os preconceitos e garantir os direitos pátrios de autonomia dos povos indígenas brasileiros, no campo da saúde, surge a Política Nacional de Atenção à Saúde dos Povos Indígenas (PNASI) para organizar o Subsistema de Saúde Indígena, para além de, propondo a adoção de um modelo especial de atenção à saúde cujos objetivos contemplem a diferenciação das organizações de serviços com o foco na proteção, na promoção e na recuperação da saúde dos povos indígenas do Brasil.

A lógica funcional dessa política está ancorada na adoção de um modelo complementar e diferenciado de organização dos serviços de saúde e, por conseguinte, pautada numa rede de atenção básica nas terras indígenas; considerando "o respeito aos sistemas de representações, aos valores e às práticas dos povos indígenas"; bem como as especificidades culturais e epidemiológicas; o desenvolvimento e o uso de tecnologias 
apropriadas; e capacitação dos profissionais para uma atuação antropologicamente orientada. Configura, assim, conforme Souza e Barbosa (2011), um Subsistema de Atenção à Saúde engajado no compromisso intercultural:

A diversidade étnica brasileira é uma característica peculiar que faz do Brasil um país multicultural, graças ao patrimônio cultural dos diversos grupos sociais formadores da sociedade nacional. Dentre as contribuições desses grupos destacam-se as das nações indígenas, povos considerados nativos uma vez que originariamente constituíram comunidades locais nas terras brasileiras, pelas quais lutaram arduamente contra a ação arrebatadora dos colonizadores europeus. Apesar do extermínio sofrido muitas populações indígenas resistiram e atualmente seus integrantes são reconhecidos como sujeitos de direitos, que devem ser promovidos e protegidos pela ordem jurídica nacional, em razão da tutela do patrimônio cultural da humanidade, da qual faz parte a identidade indígena. (SOUZA E BARBOSA, 2011:1).

O Subsistema estabeleceu a criação de 34 (trinta e quatro) Distritos Sanitários Especiais Indígenas (DSEI) a partir dos critérios de população, da área geográfica e do perfil epidemiológico com intuito de disponibilizar serviços (recursos humanos e infraestrutura); condições de acesso aos serviços instalados em nível local e à rede regional do SUS; relações sociais entre os diferentes povos indígenas do território e a sociedade regional; e a distribuição demográfica tradicional dos povos indígenas. Nesse modelo, essa distribuição não coincide necessariamente com os limites dos estados e municípios onde estão localizadas as terras indígenas.

Dessa maneira, a proposta de criação dos Distritos Sanitários Indígenas representa um modelo de organização de serviços que visa a atenção à saúde sob responsabilidade do gestor federal (com ação complementar por estados, municípios e ONGs) com uma delimitação geográfica que contempla aspectos demográficos, etnoculturais e o acesso dos usuários indígenas aos serviços, além do controle social exercido pelos Conselhos Distritais de Saúde Indígena (BRASIL, 2002).

Em 2010, inicialmente por Medida Provisória (MP) e logo posteriormente por Decreto presidencial foi criada a Secretaria Especial de Saúde Indígena (SESAI) no âmbito do Ministério da Saúde, que substitui a FUNASA na gestão do Subsistema de Atenção à Saúde Indígena. Segundo Ferreira (2012:62) "Essa mudança inicia uma nova etapa de construção da 
relação entre o Estado e os povos indígenas no que se refere aos serviços de saúde a fim de defender entre tantas outras coisas a medicina tradicional".

Os profissionais de saúde e os gestores que se propõem a desenvolver atividades junto a esses povos deparam-se com uma situação de inversão de posições tradicionalmente estabelecidas, questionando ações de saúde centradas somente no saber médico. O número, qualificação e perfil dos profissionais das equipes serão estabelecidos de acordo com o planejamento detalhado de atividades, considerando o número de habitantes, a dispersão populacional, as condições de acesso, o perfil epidemiológico, as necessidades específicas para o controle das principais endemias e o Programa de Formação de Agentes Indígenas de Saúde (BRASIL, 2002).

Destacam-se nesta configuração os Agentes Indígenas de Saúde (AIS) - membros integrantes da Equipe Multidisciplinar de Saúde Indígena (EMSI). A definição do papel do AIS esta pautado nos princípios da promoção, prevenção, cura e reabilitação das ações de saúde previstas na Declaração de Alma- Ata e regulamentada pela Lei 8.080. Para Langdon et. al., (2006:2638), faz parte de sua formação profissional noções de "antropologia, política de saúde e organização dos serviços, bem como noções básicas de biomedicina, técnicas básicas de enfermagem e outros assuntos relacionados à saúde comunitária”. Também, deve incluir uma discussão sobre "medicina tradicional e a visão nativa do processo saúde-doença, a cura e a morte e sua relação com a cosmologia para reconhecer a especificidade cultural do grupo".

As ações de saúde prevista no PNASI, já apresentado anteriormente, devem estar articuladas entre os dois polos, o saberes da saúde tradicional e o ocidental. Em outras palavras, recomenda-se que a medicina tradicional seja integrada aos saberes da medicina científica ocidental, para tanto, as ações dos pajés, curandeiros entre outros, sejam validados na construção do cuidar dos Povos Indígenas. Para atingir suas metas de atenção integral são estabelecidas estratégias de ações de prevenção descentralizadas e com base na própria comunidade local, desta forma as ações dos AIS, grupos comunitários de saúde, curandeiros tradicionais e líderes comunitários cujas tarefas são de melhorar a saúde, aconselhando as pessoas sobre as estratégias de prevenção e de cuidados de saúde, garantam o respeito aos sistemas de representações, aos valores e às práticas no contexto intercultural (BRASIL, 2002; LORENZO, 2011:332; LANGDON et. al., 2006:2638). 
Fruto do engajamento dos movimentos sociais indígenas que já haviam participado da elaboração da PNASI em 2002, a Politica Nacional sobre o álcool de 2007, que estabelece diretrizes para redução do uso indevido de álcool a fim de se reduzir e prevenir os danos à saúde e à vida, bem como as situações de violência e criminalidade associadas ao uso de bebidas alcoólicas na população brasileira, passou a considerar as especificidades da população indígena, estabelecendo a necessidade de se produzir dados sobre o consumo de bebidas alcoólicas especificamente entre os povos indígenas e ações específicas para estes povos. Seu artigo 5.3 determina:

"Implementar o Projeto de Prevenção do Uso de Álcool entre as Populações Indígenas, visando à capacitação de agentes de saúde e de educação, assim como das lideranças das comunidades indígenas, para a articulação e o fortalecimento das redes de assistência existentes nas comunidades e nos municípios vizinhos. (BRASIL, 2001).

Segundo Guimarães e Grubits (2007), para atender essas medidas são necessário, então, pesquisas no contexto social e de saúde que envolva os diferentes povos indígenas com o intuito de melhor compreender a problemática do álcool e suas especificidades culturais e apontar um entendimento dos processos de alcoolização para obter abordagens efetivas e eficazes de prevenção e de intervenção. Abordagens essas necessárias principalmente pelo fato de o consumo abusivo do álcool ter sido verificado como uma das principais causas de mortalidade, seja pelo aumento da ocorrência de doenças como cirrose, diabetes, hipertensão arterial, doenças do coração, do aparelho digestivo, depressão e estresse, ou seja, como causa de morte por fatores externos como acidentes, brigas, quedas, atropelamentos, entre outros (GUIMARÃES \& GRUBITS, 2007:47).

Ainda segundo as autoras, é imperativo "historicizar o alcoolismo desde etapas mais remotas, passando pelas dificuldades de sua compreensão e da sua aceitação como doença, até as dificuldades diagnósticas em função da diversidade de significação social e cultural" (GUIMARÃES \& GRUBITS, 2007:49). Portanto, refletir sobre o uso e o abuso do álcool pelos Xerentes, povo indígena estudado nesta pesquisa, é importante para se compreender e delimitar abordagens efetivas e eficazes de prevenção e de intervenção na comunidade. 


\subsection{O POVO AKWẼ-XERENTE E O USO ABUSIVO DE ÁLCOOL.}

Acredita-se que viviam cerca de 5 (cinco) milhões de pessoas quando Pedro Álvares Cabral, em 1500, chegou ao Brasil. Sendo hoje esse contingente populacional reduzido a pouco mais de 896.000 mil pessoas, 305 etnias (BRASIL, 2010). Segundo Luciano-Baniwa (2006), não existe nenhum povo, tribo ou clã com a denominação de índio. Na verdade, cada “índio" pertence a um povo, a uma etnia identificada por uma denominação própria, ou seja, a sua autodenominação, como Akwẽ-Xerente, Akwẽ-Xavante ou simplesmente Xerente e Xavante.

Para Melatti (2006:32), a definição de índio, portanto, julgando a imperativa necessidade de se estabelecer critérios, dados os cruzamentos e, consequentemente, o nascimento dos mestiços, brancos com índios (mamelucos), negros com índios (cafuzos) e, ainda, mamelucos com cafuzos se pautam então em 5 (cinco) categorias de definição:

1) Critério racial, constituindo o mais antigo, definindo o índio como uma entidade racial evidenciado por características físicas biológicas distintas daquelas dos conquistadores europeus;

2) Critério legal, que defini o índio desde a época de colônia como sendo todas as pessoas que satisfizessem às características definidas por lei;

3) Critério cultural, compreendido como sendo os elementos que não são transmissíveis pelo modo biológico (p.ex. genética), neste caso, inclui-se os hábitos e crenças adquiridas pelo aprendizado formal e informal;

4) Critério do desenvolvimento econômico, que o próprio nome já o define, categorizando o "ser índio" como todo aquele que possui deficiências econômicas concretas do ponto de vista qualitativo e quantitativo, sendo o mais aplicado para traçar ações de fomento para o melhoramento local e da promoção social;

5) Critério da identificação étnica, entendido como o "ser índio" por eles próprios e pela população que o cerca, ou seja, a denominação e a autodenominação.

Existe uma convenção técnica das Nações Unidas, de 1986, que diz que entre os povos indígenas existem alguns critérios de autodefinição mais aceitos, embora não sejam únicos e nem mutuamente excludentes:

1) Continuidade histórica com sociedades pré-coloniais. 
2) Estreita vinculação com o território.

3) Sistemas sociais, econômicos e políticos bem definidos.

4) Língua, cultura e crenças definidas.

5) Identificar-se como diferente da sociedade nacional.

6) Vinculação ou articulação com a rede global dos povos indígenas.

Segundo dados do Sistema de Informação a Assistência de Saúde por Etnia (SIASI), a população indígena tocantinense corresponde a 10.542 pessoas. Na distribuição por Distrito Sanitário Especial Indígena e Etnia no Tocantins, os Akwẽ-Xerente são a maior população do Estado. As populações assim se distribuem: os $1^{\mathrm{o}}$ Akwẽ-Xerente (3.357 pessoas); $2^{\mathrm{a}}$ Khaho (2.800 pessoas); $3^{\mathrm{a}}$ Apynaye (2.164 pessoas); $4^{\mathrm{a}}$ Javaé (1.385 pessoas) e $5^{\circ}$ Karaja Xambioá (269 pessoas).

Esta área está sob execução da FUNAI (Fundação Nacional do Índio) e foi a primeira a ser demarcada através do Decreto Presidencial 76.999 de 19 de setembro de 1972. Possui limites leste e oeste nas respectivas margens dos rios Sono e Tocantins, ao norte a área faz fronteira com o município de Pedro Afonso, e ao sul faz divisa com o município do Lajeado (LUZ, 2005).

Os índios Xerente (Akwẽ-Xerente ou Akwen-Xerente) pertencem ao grupo linguístico Macro-Jê, que segundo Rodrigues (1986 apud SOUZA, 2008) encontra-se entre as línguas ameaçadas em extinção. A autodenominação Akwẽ-Xerente, de acordo com Maybury-Lewis (1984 apud DE PAULA, 2000), aparece na literatura de viajantes e etnólogos com diferentes grafias (acuen ou akwen, Šerentes por Curt Nimuerndajú). Esse grupo é, em sua maioria, bilíngue, com exceção das crianças que até os oito anos falam somente a língua materna que falada no ambiente familiar e intertribal, enquanto que o português é usado para a comunicação interétnica.

Os Akwẽ-Xerente ocupam atualmente o território localizado entre 8 e 10 graus de latitude sul, inserido no município de Tocantínia, cidade localizada na região central do Estado do Tocantins, a $75 \mathrm{Km}$ de Palmas, Capital do Estado. Possui, segundo o Instituto Brasileiro de Geografia e Estatística (IBGE), no censo de 2010, uma área de 2601,587 km² e uma população de 6598 habitantes, apresentando uma densidade de 2,54 hab./km². Cerca de 1/4 da população (3.151) é composto por índios da etnia Xerente que residem na cidade e nas 
62 aldeias que integram as reservas indígenas Xerentes, com 183.542 hectares de área demarcada (Fonte: SIASI - FUNASA/MS, 2012; IBGE, 2012).

Segundo Giraldin (2010:32), os Akwẽ-Xerente organizam-se socialmente em duas metades (Doi e Wahire), compostas cada uma por três clãs exogâmicos e patrilineares: Kuza, Kbazi, Krito Wahire, Krozake e Krẽprehi, respectivamente. Além dos clãs, cuja afiliação é definida pela filiação patrilinear, os Akwẽ-Xerente possuem também uma divisão em quatro classes cerimoniais, que são: Krara, Krerekmo, Amnorowa e Akemha. O pertencimento a uma dessas classes é definido pela posição de nascimento da pessoa no rol de filhos de um homem (MELO, 2010 apud OTENIO, 2007)

Assim, o primeiro filho pertencerá à classe cerimonial do pai. $\mathrm{O}$ segundo a outra classe, o terceiro em outra e o quarto na última. Se houver um quinto filho, voltara a ser afiliado à classe do pai. Essas quatro classes, no passado, eram as responsáveis pela iniciação masculina no warã (pátio, local cerimonial e instituição de formação), além de terem prerrogativas específicas no ritual de nominação masculino e feminino (MELO, 2010 apud OTENIO, 2007).

Historicamente, os Akwẽ-Xerente passaram por um colapso populacional nos primeiros anos do século XIX, um declínio populacional que foi estancado e depois revertido devido a uma série de melhorias na assistência à saúde realizada primeiramente pela Fundação Nacional do Índio (FUNAI), depois Fundação Nacional de Saúde (FUNASA) e, hoje, pela Secretaria Especial de Saúde Indígena (SESAI). Esse crescimento se deu, principalmente, com a melhora no saneamento básico, cobertura vacinal do sarampo e da febre amarela, do inquérito de Chagas e da Leishmaniose, entre outros (BRASIL, 2002).

De acordo com Luz (2005), no ano de 1825, os Akwẽ-Xerente eram cerca de 4.000 indivíduos, já por volta do ano de 1900, eram cerca de 300 indivíduos, apenas. Em 1929, 800 indivíduos e já, em 1957, cerca de 350. Atualmente, de acordo com o IBGE (2012), a população atinge a marca de 3.151 indivíduos.

Esses dados evidenciam como o povo Akwẽ-Xerente enfrenta um processo de transformações nos âmbitos sociais, políticos, econômicos e principalmente culturais após a história de contato com o não índio. Esse contato, desde o período da Capitania de Goiás (1749), é marcado por conflitos. A partir da publicação da Carta Régia, de 5 de setembro de 
1811, foi dado um novo rumo à produção agropecuária e ao comércio na região, com a utilização do rio Tocantins como via de transporte, concedendo privilégios àqueles que viessem se estabelecer às suas margens. Conforme Giraldin (2002):

1. Permitiam-se guerras ofensivas contra os índios e a possibilidade de escravizar aqueles que fossem aprisionados por um período de dez anos, ou durante o tempo que durasse a sua ferocidade.

2. Isentava-se, durante dez anos, o pagamento de dízimos para aqueles que fossem ocupar as terras dos índios (Carta Regia do Príncipe Regente D. João..., apud, GIRALDIN, 2002:46).

Além dos conflitos permeados pela demarcação de terras indígenas, as pesquisadoras observavam que esse contato cultural entre o não índio e índio resultou para o povo AkwẽXerente demandas e desejos antes inexistentes como, por exemplo, a transformação da relação entre a necessidade e o consumo; o significado social da educação como estratégia de se buscar um futuro melhor; as concepções emergentes sobre namoro e casamento; as mudanças nas relações entre homens e mulheres, entre outros elementos que penetraram o universo do povo Xerente fazendo-os repensar seu lugar social (MILHOREM \& CRUZ,2010:37).

O estudo de Ferreira (2011), por sua vez, na área da educação, particularmente a de Educação de Jovens e Adultos (EJA), contribuindo para a reflexão crítica sobre essas transformações, revela como as práticas escolares são descontextualizadas "da e para" sociedade Xerente, uma vez que há escassez do protagonismo indígena na formulação de política de educação. Segundo o autor, os Xerentes esboçam uma "identidade cultural fragilizada e facilmente dominada" por grupos que têm consciência dessa falta nas decisões. Um outro estudo que explora essas transformações ocorridas entre os Xerentes a partir do contato com o não índio é o de Sifuentes (2007) que trabalhou a questão da reconstrução da identidade cultural Xerente a partir das constantes hibridizações linguísticas, étnicas e culturais reedificadas e projetadas no contexto cultural não indígena.

Silva e Sousa (2015:117), em um artigo intitulado Alcoolismo e uso do álcool entre os Akwen Xerente do Tocantins: A perspectiva indígena, propõe a problematização das representações acerca do alcoolismo entre os Akwen Xerente presentes nos discursos de diversos atores, considerando a perspectiva indígena como contraponto das representações 
negativas dos xerentes como, por exemplo, bêbados. Esse revela a carência de capacitação técnica-administrativa significativa por parte da equipe multidisciplinar que atua entre os Xerente. Segundo as autoras, a problemática do consumo da bebida alcoólica revela uma decadência de ações e intervenções de saúde oriundas da falta de capacitação para o diálogo intercultural.

Sobre essas representações negativas, o estudo de Caldeira (2011), realizado com estudantes e professores de uma escola de ensino médio na cidade de Tocantínia, sobre a constituição discursiva de identidades étnicas em um espaço escolar multicultural, desvela que a não aceitação dos índios nesse espaço escolar, por uma parcela dos estudantes, é calcada, dentre outras, na representação do índio Xerente como bêbado e preguiçoso.

Em todos esses estudos, portanto, o uso e abuso da bebida alcoólica ancoram representações sociais negativas sobre os Xerentes. O que reforça a afirmação de OliveiraReis (2001) ao apontar que o consumo desordenado da bebida alcoólica, entre outras consequências, vem acarretando diversos conflitos não apenas nas relações pessoais que resvalam para conflitos clânicos como também entre aldeias e entre índios e não índios.

A compreensão desses conflitos e posteriores modificações na cultura Xerente, devido ao contato interétnico, é fundamental para uma atuação contextualizada dos profissionais de saúde. Apesar da situação de vulnerabilidade social também estar presente nas populações indígenas, o fato de a prática de saúde ser realizada no território indígena, em que as lideranças e chefias são estabelecidas de acordo com a cultura de cada etnia, leva os profissionais de saúde a uma posição mais horizontal com os usuários (SOUZA e GARNELO, 2007). Haja vista que a atuação das equipes de saúde junto à população indígena deve partir primeiramente do consentimento das comunidades e da compreensão de seu funcionamento. Por isso, como pontua Lorenzo (2011:338):

Existe quase um consenso de que o respeito às crenças, à diversidade de visões de mundo e às práticas tradicionais de autoatenção são posturas consideradas eticamente corretas nas relações estabelecidas por profissionais de saúde e seus pacientes, independentemente de se tratar de uma relação interétnica - exatamente o tipo de relação que tem sido menos discutido no escopo da bioética clínica. A diversidade cultural representada pela grande quantidade de povos indígenas no Brasil oferece um contexto muito interessante para se refletir sobre a construção de uma bioética clínica capaz de atuar nas relações interétnicas promovidas por políticas públicas que visam garantir a oferta de bens e serviços de saúde ocidentais a comunidades tradicionais historicamente excluídas. 
Refletindo sobre essa necessidade de respeito às crenças, à diversidade de visões de mundo e às práticas tradicionais de auto-atenção na saúde indígena, pude constatar, no período em que atuei como enfermeiro no município de Tocantínia (2006 a 2009), inúmeros episódios oriundos do abuso da bebida alcoólica e de seus nefastos efeitos, que revelaram a falta de oferta de bens e serviços de saúde adequados ao contexto. Era comum, principalmente nos dias de segundas-feiras na praça da cidade, o regular ajuntamento de índios vendendo seus artesanatos, em muitos casos, para comprar mantimentos no comércio local e consumir a pinga, bebida de maior consumo entre os índios Xerentes.

$\mathrm{O}$ alto consumo dessa bebida gerava agravos como prejuízos financeiros na venda dos seus artesanatos; como brigas entre índios e não índios, como também entre os próprios índios; como ferimentos e fraturas, entre outros. Após as festividades na cidade, era comum encontrar índios embriagados nos espaços públicos, até mesmo inconscientes nos bancos da praça, o que demonstra o grave problema do uso e abuso de álcool entre os Xerentes. Havia muitas mortes por acidente e por afogamento envolvendo índios alcoolizados.

Muitos índios lesionados em algum episódio, sempre após o consumo da bebida alcoólica, procuravam a unidade básica de saúde para atendimento. Nesse contexto, convivi diariamente com a necessidade latente de capacitação dos profissionais para o atendimento na comunidade marcadalconstituída por relações interculturais; e de ações de prevenção e de combate do uso e abuso da bebida alcoólica, de onde surgiu a necessidade de investigar de forma mais aprofundada as percepções dos profissionais sobre o problema do uso e abuso de bebidas alcoólicas entre esse povo e da atenção de saúde dirigida a este problema. 


\title{
5. O PERCURSO METODOLÓGICO DA PESQUISA.
}

Para operacionalizar a pesquisa, parti de um modelo de pesquisa qualitativa que leva em consideração a pluralização das esferas da vida e que permite identificar no corpus estruturas de poder naturalizadas em um contexto sócio-histórico definido (FLICK, 2004:17). Esse tipo de pesquisa consiste em um conjunto de práticas materiais e interpretativas que podem dar visibilidade às percepções dos profissionais de saúde que atuam entre o povo Akwẽ-Xerente sobre o uso e o abuso da bebida alcoólica e sobre como atua elou deveria atuar o Subsistema de Saúde Indígena na prevenção e assistência a esse fenômeno.

$\mathrm{O}$ interesse nesse modelo de pesquisa adotado se justifica pelo fato de o método qualitativo, de acordo com Minayo (2010:57), se aplicar ao estudo

\begin{abstract}
"da história, das relações, das representações, das crenças, das percepções e das opiniões, produtos das interpretações que os humanos fazem a respeito de como vivem, constroem seus artefatos e a si mesmos, sentem e pensam. (...) as abordagens qualitativas se conformam melhor a investigações de grupos e segmentos delimitados e focalizados, de histórias sociais sob a ótica dos atores, de relações e para análises de discursos e de documentos."
\end{abstract}

Assim, adoto como arcabouço teórico-metodológico, a Hermenêutica Dialética proposta por Minayo (2014:328) por nos apresentar a compreensão de castas metodológicas mais potentes dos movimentos e das atitudes de investigação, gerando significados, categorias filosóficas, consciências históricas para aquela e base de articulação de ideias criticas, negação, situações de oposição, mudanças dos movimentos de transformação da natureza e da realidade social para essa.

A hermenêutica, como arte da compreensão, trata-se de visão mais ampla que atribui à capacidade da pessoa humana, neste caso do pesquisador, de se colocar no lugar do outro. É, verdadeiramente, a arte de compreender, de entender uns aos outros por meio das experiências humanas de mundo e da práxis da vida (MINAYO, 2014). Portanto, configura-se como:

Um pensamento dialético, embora muitos tenham pretensão de dizer mais do que realmente dizem, é importante ter em conta que cada individualidade é uma manifestação do viver total e, portanto, a compreensão se refere, ao mesmo tempo, ao que é comum, por meio de operações de comparação; e ao que é específico, como contribuição peculiar de cada um (MINAYO, 2014:330). 
Nessa abordagem, a compreensão não é um procedimento mecânico e tecnicamente fechado, como pontua a autora. Desse modo, a Hermenêutica Dialética busca obter os dados históricos e também a empatia do contexto do texto, dos entrevistados e dos documentos que analisa, logo, o discurso expressa um saber partilhado com outros e marcado pela tradição, pela cultura e pela conjuntura (MINAYO, 2014: 344). Por não buscar a verdade essencialista, mas o sentido que o colaborador de pesquisa quis expressar, por exemplo, durante as entrevistas, esse método é profícuo: considera o sentido da mensagem ou de uma realidade como sempre aberto em várias direções.

Minayo explica ainda que nada do que se interpreta pode ser entendido de uma única vez, e de uma vez por todas, tendo que buscar entendimento do que ficou inconsciente para cada figura humana, pois "cada realidade constitui um exercício reflexivo sobre a liberdade humana, remetendo a ideia de que os acontecimentos se seguem e se condicionam uns aos outros, mediante ao novo, e o que é novo e ser tornou realidade nunca mais poderá ser desfeito" (MINAYO, 2014: 330). E, assim, compreender, "acaba sempre sendo compreenderse" (ibidem, 2014:337).

$\mathrm{Na}$ hermenêutica dialética, as interpretações ocorrem no nível dos dados, em que os sentidos de totalidade se referem ao nível das determinações como à do recurso interpretativo pelo qual se busca descobrir as experiências empíricas no plano das relações essenciais, portanto, toma como centro da análise a prática social e a ação humana e as considera como resultados de condições anteriores, exteriores, interiores e também como práxis - o sujeito que vive, pensa, sente e reflete o mundo (MINAYO, 2014:354). A dialética é, porquanto, o

estudo da oposição das coisas entre si. Metodologicamente, ela se traduziria numa forma de abordagem: desvendar as relações múltiplas e diversificadas das coisas entre si; explicar o desenvolvimento do fenômeno dentro de sua própria lógica; evidenciar a contradição interna no interior do fenômeno; compreender o movimento de unidade dos contrários; trabalhar com unidade da análise e da síntese numa totalização das partes; co-relacionar as atividades e as relações (MINAYO, 2014: 340).

Em conformidade com o ciclo da pesquisa no método da hermenêutica dialética proposto por Minayo (2009:26), organizei a pesquisa em: fase exploratória (conforme apresentada nos capítulos anteriores) dedicada à delimitação do objeto, ao problema de 
pesquisa, aos pressupostos teóricos e metodológicos; fase do trabalho de campo destinada ao contato com os colaboradores de pesquisa, à realização das entrevistas, à transcrição e delimitação do corpus da pesquisa; e fase do tratamento do material gerado no campo designada à ordenação, classificação e análise.

Assim, ao término da fase exploratória (com o projeto de pesquisa definido), dediquei-me ao trabalho de campo buscando uma aproximação com a realidade sobre a qual formulei minhas questões de pesquisa e com os colaboradores da pesquisa na tentativa de "construir um conhecimento empírico importantíssimo para quem faz pesquisa social" (MINAYO, 2009:61). Procurei seguir as orientações de Minayo (2010) no que se refere à apresentação do pesquisador e a sua entrada em campo, na menção explícita de seus interesses e dos objetivos da pesquisa, na livre possibilidade de escolha do colaborar em participar ou não da pesquisa, na garantia de seu anonimato e nos possíveis riscos e benefícios de participação na pesquisa (conforme TCLE em anexo).

Como a pesquisa qualitativa se desenvolve "por meio de práticas interpretativas e materiais que tornam o mundo visível" (DENZIN; LINCOLN, 2005 apud FLICK, 2009:16), empreguei nessa fase a técnica de entrevista semi-estruturada para estabelecer o diálogo com os profissionais de saúde e para gerar os dados e ter acesso as suas percepções no que se refere ao problema pesquisa. Essa técnica permitiu, no contexto em questão, aos profissionais expressarem parte da realidade a sua volta em atendimento aos objetivos da pesquisa. Por isso pode ser considerada como uma técnica profícua "destinada a construir informações pertinentes para um objeto de pesquisa” (MINAYO, 2010:261).

Na fase final, fase do tratamento do material "gerado" no campo, para ordenar, classificar e analisar os dados, utilizei o Método de Interpretação de Sentidos, tal como descrito por Minayo (2009).

Ela está pautada, em uma "perspectiva das correntes compreensivas das ciências sociais que analisa: (a)palavras; (b) ações; (c) conjunto de inter-relações; (d) grupos; (e) instituições; (f) conjunturas; dentre outros corpos analíticos” (GOMES et. Al., 2005, p. 202 apud MINAYO, 2009:82). Conforme a autora é um método orientado por entendimentos advindos da Teoria da Interpretação da Cultura de Clifford Geertz (1989) e do diálogo entre as concepções hermenêutica (compreensão) e dialética (crítica). Esse diálogo me permite 
compreender o significado das percepções dos profissionais acerca daquilo que irei interpretar como também estabelecer uma crítica acerca dos dissensos e contradições dos significados encontrados e sobre as suas relações com o contexto (MINAYO, 2009:99).

\subsection{SELEÇÃO E RECRUTAMENTO DOS COLABORADORES DE PESQUISA E ROTEIRO DE ENTREVISTA}

Entre o planejamento da pesquisa e sua execução em campo deparei com um fenômeno de demissão em massa de quase a metade dos 27 profissionais de saúde do quadro funcional do DSEITocantins, pólo base de Tocantínia. Assim realizei a pesquisa com 6 profissionais que continuavam no quadro e com outros 11 temporariamente desligados. Eles foram contatados pessoalmente em seus postos de trabalho e as entrevistas tiveram início após explicação dos objetivos e possíveis riscos e desconfortos da pesquisa e assinatura do Termo de consentimento livre e esclarecido, tal como constava no protocolo de pesquisa aprovado pelo CEP-UnB n 362014.

Foi elaborado um roteiro de entrevista semiestruturada constando de quatro perguntas abertas que permitissem ter acesso, por meio de opiniões, sentimentos, explicações, estereótipos, crenças, identidades, ideologias, cosmovisões, hábitos e práticas, às percepções dos colaboradores de pesquisa sobre os aspectos que pretendíamos investigar (Vide Apêndice 1 - Roteiro de Entrevista). As gravações, devidamente autorizadas, foram transcritas e analisadas pelo método hermenêutico-dialético.

Os participantes foram codificados como PS (Profissional de Saúde), mais um número seguindo a ordem das entrevistas realizadas. Ex: PS 1.....PS10

\subsection{O CAMINHO PARA INTERPRETAÇÃO DOS DADOS GERADOS.}

Para análise e interpretação dos dados, seguimos as etapas propostas por Minayo (2009:100-102): (a) leitura compreensiva do material selecionado, (b) exploração do material, (c) elaboração de síntese interpretativa. Na etapa leitura compreensiva do material selecionado, realizei uma análise do material na busca de generalidades e particularidades organizando as categorias a partir das percepções dos profissionais de saúde por meio de sucessivas categorizações e distribuição de unidades de sentido/temas. Nessa etapa, construiuse as 4 (quatro) categorias de análise pré-estabelecidas para atender aos objetivos específicos:

(1) Causas do uso do álcool; (2) Consequências do abuso do álcool e (3) Relações 
interculturais em torno da atenção à saúde; e (4) Proposta de enfrentamento: dificuldades e desafios do abuso do álcool na atenção à saúde. Delas emergiram da leitura e interpretação as subcategorias mais estritamente ligadas às perspectivas dos colaboradores.

A partir da primeira categoria, (1) Causas do uso do álcool, agrupei as seguintes subcategorias: 1.1 Perda das funções sociais e laborais; 1.2 Modificação do padrão de uso e facilidade de acesso pela aproximidade com a cultura ocidental. e 1.3 Inabilidade intrínseca do indígena em lidar com conflito. Na segunda categoria, (2) Consequências do abuso do álcool, agrupei: 2.1 Agressividade; 2.2 Perda da função provedora; 2.3 Reforço do preconceito e 2.4 Doenças físicas. Já da terceira categoria pré-definida (3) Relações interculturais em torno da atenção a saúde emergiram a seguinte subcategoria: 3.1 Reconhecimento da necessidade de estabelecer relações interculturais; 3.2 Possibilidade de articulação de saberes; 3.3 Critica a perda das tradições pelos indigenas; 3.4 Contestação de saberes tradicionais e 3.5 Elementos Positivos e Negativos vistos na cultura indígena

Em relação à categoria (4) Proposta de enfrentamento na atenção à saúde, emergiram 5 (cinco) subcategorias: 4.1 Necessidade de politicas e programas específicos; 4.2 Necessidade de apoio as necessidades dos profissionais; 4.3 Necessidade de atenção a saúde culturalmente adequada; 4.4 Necessidades de melhorias da qualidade e acesso aos cuidados de saúde e 4.5 Proposta de prevenção.

Na etapa exploração do material analisei o material em busca de percepções implícitas para identificar e compreender representações culturais veladas, por exemplo. Segui a trajetória proposta por Minayo (2009:101): a. Identificação de ideias implícitas e explícitas nas entrevistas; b. Busca de sentidos mais amplos socioculturais atribuídos às ideias; c. Diálogo entre as ideias problematizadas, informações provenientes de outros estudos acerca do assunto e o referencial teórico adotado. Essa etapa será apresentada no capítulo dedicado à análise de dados.

E na etapa final, elaboração de síntese interpretativa, apresentada no último capítulo, apresento uma síntese interpretativa, realizando uma articulação entre os objetivos da pesquisa, os fundamentos teóricos e os dados analisados.

O quadro contendo as categorias, subcategorias e os respectivos registros de inferência dos colaboradores se encontram no anexo 2. 


\section{RESULTADOS E DISCUSSÃO.}

Dadas as características dos dados coletados, procederemos a apresentação dos resultados de forma conjunta à sua discussão, seguindo a ordem das categorias préestabelecidas e as respectivas subcategorias que emergiram da interpretação. Utilizaremos alguns exemplos dos fragmentos de discurso que constituíram as inferências para as categorias. O quadro completo, como já mencionado, encontra-se no anexo 2.

Ao investigar as principais causas do alcoolismo entre o povo Akwẽ-Xerente na visão dos profissionais, pudemos agrupar as respostas em 3 subcategorias.

A primeira delas foi a "Perda das funções sociais e laborais" que se mostrou bastante frequente entre os profissionais entrevistados. Alguns deles percebiam que a perda das formas tradicionais de viver e trabalhar tinha um vínculo direto com o abuso de bebida alcóolica.

"Quando ele está lá na aldeia, ele é um indio que trabalha planta a roça dele, caça, que sustenta a família! Então, quando ele sai dessa situação, que cai na bebida alcoólica, e fica ali um índio bêbado, tombando, (...) a família está sofrendo, né? "(PS 1)

Outros profissionais não chegaram a demonstrar uma percepção mais aprofundada sobre as mudanças culturais nas formas de vida e relações de trabalho, compreendendo a causa como a de uma ociosidade qualquer.

“o maior problema de o índio beber é a ocupação! Porque não tem! Alcoolismo não! (...) o índio bebe é porque ele não tem que fazer!” (PS 2).

"Será se eu tivesse uma qualidade de vida diferente, opções de trabalho diferente, será se eu me refugiaria na bebida?" (PS 10).

Essa perspectiva vai ao encontro do que pensam Guimarães e Grubits (2007:49) quando afirmam que o uso do álcool pode funcionar como um "agente aliviador de tensões sociais". Além disso, esses autores têm demonstrado como trabalho assalariado temporário, projetos de desenvolvimento, frentes de extrativismo tem, de certa forma, impactado na 
integridade do meio em que vivem os indígenas e em suas formas de vida produzindo, como consequência, a modificação de seus saberes, sistema econômico e organização social. É muito evidente para aqueles que trabalham com os Akwẽ-Xerente, como a proximidade com a cultura ocidental, sem qualquer forma de proteção às suas terras e formas tradicionais de vida, produziram ao longo das últimas décadas profundas transformações sociais, econômicas e culturais.

O crescimento da cidade de Tocantínia e a sua aproximação das terras indígenas; o deslocamento dos índios Akwẽ-Xerente para a cidade de Tocantínia, que não tem fonte geradora de renda e tem um comércio local ainda muito insipiente de emprego formal; a construção da usina hidrelétrica e o plantio de soja próximo das aldeias indígenas que acarretaram transformações ao meio ambiente e forçaram ainda mais o deslocamento dos indígenas para a cidade.

Observa-se hoje que o caçar, o pescar, o plantar está mais associado ao lazer, naquelas aldeias mais próximas da cidade, do que com o meio de subsistência indígena, pois as aldeia que fica mais distante, onde o transporte é deficitário, eles ainda tentam cultivar suas tradições de subsistência mas vivem em situação de grande precariedade. Nas aldeias mais próximas da cidade tem ocorrido uma migração espontânea para Tocantínia em busca de trabalho, estudo e contato e, assim, uma maior suscetibilidade ao contato ainda com o álcool.

Essa proximidade e acessibilidade ao álcool e seu uso fora dos padrões culturais tradicionais foram também percebidos pelos profissionais de saúde, cujas respostas foram agrupadas na categoria "Modificação do padrão de uso e facilidade de acesso pela aproximidade com a cultura ocidental".

Um dos profissionais demonstra muito claramente a compreensão de uma transformação das formas tradicionais de uso do álcool autoreguladas para uma forma subjetivamente e socialmente descontextualizada e prejudicial.

"Porque antes eles não eram assim! Eles bebiam de ano em ano! Eles faziam a própria cachaça deles! Quando eu cheguei aqui em Tocantinia no ano de 95, você não via essa indiarada aqui na rua bêbada!" (PS 4) 
Trata-se de uma percepção que vai ao encontro de diversos trabalhos, tais como o de Lagdon (2013) e Sousa e Garnelo (2006), que chamam a atenção para a existência de um uso culturalmente regulado de bebidas alcoólicas de produção própria por vários povos indígenas e a complexidade dos fatores que levam ao alcoolismo entre esses povos, a qual não é possível de ser abordada apenas por uma perspectiva biomédica individualizada.

Outros profissionais referem-se mais diretamente à facilidade de acesso dos povos indígenas vivendo nas periferias de cidades, sem se remeter a complexidade do processo transformador.

“(...) facilidade deles, o acesso deles pra bebida está muito fácil! Em um supermercado, eles conseguem comprar! Se eles vão em um boteco, eles conseguem comprar! Né?! Se eles vão em Miracema, eles conseguem comprar! Se eles vão em qualquer lugar, eles conseguem comprar!” (PS 9)

Mas é importante pensarmos que o indígena possui um papel social significativo na aldeia, e ao sair da aldeia, o índio se entrega a uso e abuso da bebida alcoólica como fator aliviador de tensões. Essa facilidade de acesso ao álcool evidencia a influência da cultura ocidental, por meio das transformações causadas em nome do desenvolvimento econômico, no processo de alcoolização do índio. Como pontua Júnio (2014), não são necessariamente efeitos do álcool em si, mas uma resposta socialmente esperada naquele contexto cultural de não aceitação, não pertencimento, não desencaixe.

Podemos compreender, portanto, as relações de causalidade do abuso de álcool entre o povo Akwẽ-Xerente, assim como por outros povos já relatados na literatura, em parte pelo que Bauman (1999) designa como "crise de identidade cultural”, conceituada como uma crise gerada pela perda do sentido de pertencimento e de localização no tempo e no espaço em sua própria comunidade. Essa já não é mais a mesma, não é mais segura após tantas e rápidas transformações. O índio precisa vir para a cidade para sobreviver, tentar estudar e trabalhar, mas não consegue se encaixar no estilo de vida da sociedade capitalista. Não consegue trabalhar para sustentar a sua família na cidade, assim como fazia na aldeia. Não consegue pertencer a essa nova comunidade, encontrando-se num estado de embriaguez que reforça ainda mais os conflitos, a demarcação da diferença e a intolerância étnica e cultural. O índio 
Akwẽ-Xerente visto como "bêbado" é o diferente que "tomba" na cidade, que distoa dos demais sujeitos e, por isso, não possui um papel social a desempenhar ali.

A terceira subcategoria de causas nas quais conseguimos enquadrar as respostas dos profissionais exemplifica bem a existência de uma visão estereotipada do indígena e deixa entrever, de certa forma uma compreensão de superioridade moral dos brancos. Trata-se da subcategoria "Inabilidade intrínseca do indígena em lidar com conflito".

Eles são muito fracos para conflito. Ou eles adoecem do nada ou, então, vão beber muita cachaça por causa dos conflitos! (...) Eles bebem por época: os problemas familiares, que eles não sabem resolver! (PS 3).

(...) porque tem muito adultério! Muito muito mesmo! Então, assim: aí vêm os conflitos familiares! E eles não aguentam conflito! (PS 2).

Obviamente, como já amplamente relatado o uso de bebida alcoólica pode funcionar como fator aliviador de tensões e conflitos. E obviamente também, as próprias condições sociais e as perdas dos vínculos culturais nas formas de viver são por si só fatores potencializadores de conflito. Mas, o que chama atenção aqui é a percepção do indígena como "fracos para conflito", ou como pessoas que " não sabem resolver" seus conflitos familiares, ou ainda em que o "adultério" é mais frequente..., sem se questionar se essa categoria jurídico-moral ocidental se adéqua à realidade daquele povo. É necessário, portanto, analisar o problema do alcoolismo na perspectiva defendida por Neves (2004) de interlocução de saberes para que o consumo de álcool por povos indígenas seja compreendido verdadeiramente dentro do contexto de valores, normas e condutas culturalmente mediadas. Caso contrário corremos o risco de que o uso abusivo de álcool, reforce como relata Langdon (2013) uma imagem negativa do índio como ignorante, preguiçoso e agora também adultero e fraco para o conflito.

Isso aponta também para a necessidade de uma capacitação mínima em antropologia da saúde para os profissionais, como forma de melhorar não apenas a articulação de saberes em saúde, mas também as próprias relações éticas entre profissionais e indígenas, tal como defende Lorenzo (2010). Lazzarotto et al. (2007) também defendem a necessidade de um 
melhor conhecimento sobre os costumes, os valores, as crenças e as demais características que facilitem a comunicação e mesmo alguma função de aconselhamento, quando o profissional de saúde é demandado para isso.

Desse modo, as causas do alcoolismo entre o povo Akwẽ-Xerente, como nos demais povos indígenas devem ser problematizadas de maneira integrada aos aspectos culturais e sociais em que estão inseridos para que o abuso do álcool não seja vista como algo natural que faz parte dos estilos de vida e dos gostos pelos quais os Akwẽ-Xerente apreciam o mundo e se comportam nele. É necessário compreender o sistema de práticas em que os AkwẽXerente se incluem, os valores, crenças e representações veiculadas em seu meio social ocidentalmente transformado.

Ao abordar as consequências do uso do álcool, a "agressividade" surgiu como o problema mais frequente enfrentado na comunidade pelos Akwẽ-Xerente. A agressividade e a violência são compreendidas como se dirigindo às relações familiares e as transformando.

"geralmente eles ficam mais é agressivos, né?! Não são todos, mas quando eles tem agressividade, geralmente tem o álcool envolvido...” (...) Bate nas esposas, nas crianças, entendeu? Ah! Que é o que normalmente não só o indio faz (PS 1).

Observe-se que há uma percepção de transformação das relações, a violência contra a mulher e a criança é compreendida como semelhante à dos brancos. Não são apenas os índios que, sob efeito de álcool, praticam violência domiciliar.

Interessante notar que essa percepção generalizante dos efeitos do álcool sobre o psiquismo encontram suporte em alguns estudos neuro-psicológicos. Alguns autores apontam que a capacidade de compreender a emoção associada à linguagem está prejudicada, resultando em erros de julgamento e, consequentemente, perdas importantes nas interações sociais. Os autores ressaltam que a perda da capacidade de julgamento e dificuldade de interpretar o significado da linguagem, associados à agressividade resultante da ação psicoativa do álcool, são importantes geradores de violência (DE ALMEIDA, PASA \& SCHEFFER, 2009:255).

Mas, essa violência é vista também como ultrapassando a dimensão familiar e atingindo a comunidade como um todo. 
“As consequências é briga na aldeia” (PS 4).

Ou seja, ela predispõe e potencializa conflitos que tem origem nas próprias circunstâncias negativas provocadas pela situação social do grupo e perda de seus laços tradicionais. Minayo (1994) apoiada nos estudos de Bouding, afirma as alterações profundas provocadas nas as práticas de socialização, levando os indivíduos a aceitar ou a infligir sofrimentos, segundo o papel que lhes corresponda, de forma "naturalizada".

Essa agressividade irá ainda ultrapassar essa dimensão intracomunitária e atingir os contatos interculturais e os comportamentos fora da aldeia, o que como veremos mais tarde, irá contribuir para o fortalecimento do preconceito na cidade de Tocantínia, contra os índios Akwê-Xerente. Uma dessas formas de agressividade extra-comunitária foi relatada como se dirigindo aos próprios profissionais de saúde.

(...) chegaram a me ameaçar, chegaram lá na unidade; eu tive que sair de lá correndo, sabe?! Devido à bebida! Fora da bebida, eram pessoas muito boas! Mas na hora em que bebiam, assim, se transformavam (PS 8).

Ainda que possamos encontrar em trabalhos como o de Almeida, Pasa e Scheffer (2009), uma atribuição especificamente neurobiológica pelas propriedades psicoativas da substância que estimulam comportamentos violentos, seria uma abordagem muito redutora tentar compreender as alterações de comportamento apenas por essa via. É importante, como defende Neves (2004), estar atento à importância de se compreender os modos moralizantes de representação do consumo da bebida alcoólica e seus efeitos sobre as relações sociais e sua atribuição como fator dissolvente de unidades sociais fundamentais, tais como a família e o trabalho. E isso precisa ser feito considerando-se as matrizes culturais e as circunstâncias sociais dos povos.

Daí também a necessidade que aponta Alfaro (1993) já há mais de 20 anos em se produzir estudos que tratem da problemática do consumo abusivo da bebida alcoólica e a agressividade entre povos indigenas, pois se fazem urgentes novos elementos para a compreensão do fenômeno. Nessa perspectiva, o estado de saúde de uma população não pode ser dissociado de seu modo de vida e de seu universo social e cultural. 
Outras formas de compreensão frequente das consequências do abuso de álcool entre os Akwê-Xerente pelos profissionais de saúde puderam ser agrupadas sob a subcategoria Perda da função provedora. Duas trechos do discurso do primeiro profissional entrevistado exemplifica bem essa percepção:

"Quando ele está lá na aldeia, ele... ele é um índio que trabalha... que planta a roça dele, que caça... né?!... que sustenta a família! Então, quando ele sai dessa situação, que cai na bebida alcoólica, e fica ali um índio bêbado (...) a família está sofrendo, né?(PS1)

(...) algum artesanato que eles fazem, pra comprar alimentação, e a mulher fica lá na aldeia. E ele vem, vende e, antes dele fazer a compra pra ele levar, ele acaba bebendo, né?!... Gastando dinheiro daquele pouco que eles ganham do artesanato, e a família fica lá com fome (PS 1).

Aqui se encontra uma compreensão, tanto dos efeitos diretos do abuso de álcool, como da predisposição ao abuso pela perda das estruturas sociais tradicionais. Os estudos de Zanatta, Garghettib e Luccac (2012) demostra claramente que a perda das funções provedoras é uma fonte de geração de stress por parte dos usuários de álcool e outras drogas. Como podemos observar no trecho acima, a venda de subsistência entre os Akwẽ-Xerente é baixa e ainda, o "pouco que eles ganham, eles gastam com a bebida alcoólica", demonstra uma fragilidade tanto social (com foco na subsistência) quanto às relações familiares contribuindo para o conflito e suas consequências, que já foi apresentado anteriormente.

As perdas das formas tradicionais de estrutura familiar e relações de trabalho surgiram no estudo tanto como causa, quanto como consequência do abuso de álcool e parece claro esse círculo vicioso formado. A fim de minimizar essas problemática de "prover" faz-se necessárias políticas intersetoriais que promovam a recuperação de algumas estruturas sociais, em especial é claro o acesso a terra e uma rede de apoio capaz de minimizar os estigmas e os estereótipos atribuídos aos usuários da bebida alcoólica, a fim de que sejam combatidos e desconstruídos, para que tenham condições, diante do processo de reabilitação, de retomar a vida em sociedade. 
Neste sentido, a percepção de que o alcoolismo promove o "reforço do preconceito", outra subcategoria das consequências onde foi possível enquadrar as percepções dos colaboradores, o que pode ser muito bem ilustrado no trecho abaixo.

"Reforça o preconceito que as pessoas já têm contra o índio, com o indígena, em relação ao indígena. Porque eles... Quando, assim, se tem dez em uma etnia, por exemplo, que bebe, que fica bêbado na rua e tal, as pessoas já generalizam, né?! Eles acham que todos os indígenas são desse jeito!" (PS 11).

Podemos notar que o profissional já percebe um preconceito de partida contra o indígena e que em função do abuso de bebida alcoólica essa tendência aparece de forma mais acentuada, podendo causar as generalizações, também citada por Langdon (2013) da compreensão do indígena como indivíduo indolente e preguiçoso. No caso dos AkwẽXerente, vemos que a população local estigmatiza e generaliza o índio como bêbado e, portanto, perigoso devido ao abuso do álcool, tornando-se um fator complicador das relações interculturais locais.

Vale a pena ressaltar, que ainda que as "doenças físicas" terem sido mencionadas e puderem, portanto, ter sido agrupadas em uma subcategoria de consequências, elas foram citadas de forma mais lacônica e breve que as consequências sociais, culturais e intrafamiliares.

"O índio bebe como consequência tem o aparecimento de varias doenças. Eles ficam doentes..." (PS 3).

“E, depois, as cirroses hepáticas - os tumores iguais nós! Não tem diferença!” (PS 4).

Existem diversas evidências que permitem caracterizar o papel do álcool como fator de risco para doenças e morte, além de diversas consequências sociais negativas. Essa constatação é reforçada pelos colaboradores de pesquisa sendo o foco da assistência voltado para as doenças clínicas (doenças física orgânicas) decorrentes da dependência, que ocorrem mais tardiamente. Esse fato é de extrema importância, pois, no contexto preventivo, 
o primeiro problema decorrente do uso do álcool e a primeira intervenção voltada para esse problema é, segundo Junqueira (2010) muito recente.

Essa pouca expressão dos problemas físicos provocados pela bebida alcoólica no discurso dos colaboradores podem ser devido também ao fato deles atuarem na atenção básica, não convivendo tão diariamente com os internamentos provocados pelas lesões orgânicas graves, mas podem também ser um sinal da eloquência dos problemas sociais agravados pelo abuso de álcool.

Entretanto, dado potencial lesivo do uso abusivo de álcool e alcoolismo propriamente dito, esperava-se um relato mais rico desses problemas. Segundo Alarcon (2012), além das lesões mais frequentes envolvendo disfunção e ou câncer de fígado, pâncreas, glândulas em geral, coração, vasos sanguíneos e tubo digestivo, o uso contínuo e abusivo envolve maiores riscos para hipertensão arterial, arteriosclerose, infarto do miocárdio, derrames cerebrais, e diabetes, condições com as quais a atenção básica lida mais frequentemente.

A abordagem aos profissionais de saúde quanto suas percepções sobre as possibilidades de intervenção para prevenção e tratamento do uso abusivo e alcoolismo, precisou evidentemente passar por um enfoque sobre a compreensão das relações interculturais em torno da atenção à saúde, que foi em última análise a categoria predefinida.

Uma primeira subcategoria de respostas puderam ser agrupadas como "Reconhecimento da necessidade de estabelecer relações interculturais"

(...) eles tem a cultura deles, né?! E na cultura deles, estão certo! Estão certo! Cada um na sua cultura não está certo? Né?! Então, assim, eles discordam muitas coisas, assim, que a gente acha... Pra gente é um absurdo, e pra eles é normal! Entendeu?(PS 2).

(...) na comunidade indígena, a gente não tem que esperar que eles venham a se adaptar à gente; a gente tem que se adaptar com eles, né?! Não adianta você chegar lá querendo mudar as coisas de uma hora pra outra, porque você não consegue, né?! Se você bater e insistir nisso, você vai pegar uma resistência, não é?! (PS 3).

Observa-se no discurso dos profissionais um esforço em demonstrar respeito pelas diferenças culturais, ainda que não atinjam um descentramento necessário a uma busca de simetria nas relações interculturais "pra gente é um absurdo, e para eles é normal”, a própria noção de "absurdo", demonstra um estranhamento antropologicamente pouco orientado. Mas 
há pelo menos sinais de uma busca de compreender a relatividade dos costumes e valores: “eles tem a cultura deles, né?! E na cultura deles, estão certo! Estão certo!”.

Um maior grau de responsabilidade dos profissionais de saúde para o estabelecimento de relações interculturais com os Akwẽ-Xerente, em torno da saúde, aparece evidenciado no trecho: "a gente não tem que esperar que eles venham a se adaptar à gente; a gente tem que se adaptar com eles". Torna-se notória a identidade individual e coletiva dos indígenas em relação aos cuidados em saúde. Logo, a cultura parece ser compreendida como importante para a modificação de comportamentos prejudiciais à saúde e para o entendimento das expressões no modo de encarar a vida, permitindo ao profissional obter significados que lhe são atribuídos, nos valores que os distinguem.

De acordo com Granado (2004:69) quando lidarmos com relações de fronteiras culturais, ou como denominamos, relações interculturais, entre as culturas indígenas e as culturas que hegemonicamente predominam na sociedade ocidental, entre as sociedades indígenas e a sociedade envolvente que é a sociedade brasileira (representada pela cultura hegemônica), buscamos, compreender como se constituem, a partir de suas autoridades e tradições, a formação da pessoa, elemento esses presentes na cultura Akwẽ-Xerente. A força das estruturas culturais parece ser reconhecida quando PS3 diz: "Não adianta você chegar lá querendo mudar as coisas de uma hora pra outra, porque você não consegue, né?! Se você bater e insistir nisso, você vai pegar uma resistência, não é?!” (PS 3).

No mesmo sentido, parece já circular entre as percepções dos profissionais a importância da articulação de saberes na direção de um cuidado integral. Esses trechos foram reunidos na subcategoria "Possibilidade de articulação de saberes", dos quais exemplificamos dois fragmentos de discurso:

"Mas você vai e conversa com o pajé; você explica que o pajé vai fazer a parte dele, e você também vai fazer a sua. (PS 2).

Já tem uns que acredita no pajé! Já tem outros que acredita na saúde, né?! Então, tem vez que eles procuram... Aqueles que mais acreditam no pajé, primeiro, eles vão no pajé! Depois se eles não conseguirem a cura, eles vão na saúde! Do mesmo jeito é os que vai na saúde e se vai, e não consegue a cura, eles vão atrás do pajé!(PS 6). 
Ainda que os profissionais mencionem essa articulação, não se evidencia um trabalho em conjunto, propriamente articulado, mas antes uma divisão do trabalho, cada um fazendo a sua parte, ou o paciente indo em busca separadamente, em momentos distintos, do pajé ou da medicina convencional. No mesmo sentido, a busca pelo pajé não parece ser a nomeada como busca pelo campo da saúde: “...depois se eles não conseguirem a cura, eles vão na saúde”. Dessa forma não foi possível perceber através apenas dos discursos, se essa integração realmente existe. Sua constatação necessitaria provavelmente de um método de observação participante para que se pudesse concluir de forma mais segura. De qualquer forma, só o fato dessa articulação ser mencionada, tem um valor pois pode significar a abertura dos profissionais para um capacitação nessa área mais aprofundada.

Outro elemento interessante emergido dos discursos foi a expressão de posicionamentos agrupados sob a crítica da perda "critica a perda das tradições pelos indígenas" que representou outra subcategoria, muito bem exemplificado neste fragmento do PS4.

Porque hoje, o indígena está muito, assim, remédio, remédio, remédio, e esqueceu da tradição... da Medicina tradicional - que, nós temos aí uma reserva cheia e rica de plantas e de coisas que eles podem utilizar ainda, né?! E esqueceram! E eu acho que isso também é culpa nossa, de certa forma, em introduzir isso na cultura deles, né?! (PS4).

Se por um lado pode-se notar uma preocupação com o respeito pelas formas tradicionais de cura e necessidade de articular a atuação, por outro há também um reconhecimento do processo de hipermedicalização ocidental enquanto prática de cura, visto no discurso do profissional de saúde, "esqueceu da tradição". Essa perda da tradição apontada pode ser explicada pelos anos de contato com a cultura ocidental que originariamente desencadeou vários reflexos na cultura indígena Akwẽ-Xerente. Esses elementos que podem ser exemplificados, desde os trabalhos de Galvão (1957) pela retração dos territórios de agricultura de caça e coleta, a diminuição de população em consequência de contágio de doenças, a modificação de status e prestígio social advinda da posse de artigos importados, a desorganização das instituições sociais, são agora também apontados em relação a uma oferta de saúde que demonstra sua incompetência em valorizar práticas culturais de autocuidado e formas tradicionais de abordagem à saúde. E o profissional 
reconhece que é "culpa nossa", que fomos nós a introduzir essas práticas de forma impositiva à cultura deles.

Entretanto, podemos dizer que entre os Akwẽ-Xerente não haja a perda da tradição, apenas uma mescla dos saberes culturalmente assimilado devido a anos de contato com a população ocidental. Isto porque eles preservam a figura do pajé e de seus saberes tradicionais, como veremos a frente na fala dos profissionais de saúde.

Apesar dessa tendência de respeito intercultural e de busca de articulação de saberes, foi possível encontrar uma perspectiva conflitante, algumas vezes no discurso do mesmo profissional quanto às práticas tradicionais, caracterizando muitas vezes contradições internas entre a afirmação do respeito e consideração a essas práticas e o reconhecimento de suas possibilidades de êxito. Essas perspectivas conflitantes foram agrupadas na subcategoria "Contestação de saberes tradicionais", das quais apresentamos alguns dos trechos entre os mais significativos:

Porque o pajé manda tirar o remédio! Você entendeu? E bota só o dele!" (PS2)

O pajé, ele acha que aquilo é certo! Né?! E a gente tem que respeitar a postura e a questão de olhar eles como uma pessoa de referência em relação à saúde! Mas, ao mesmo tempo, a gente tem que mostrar que as formas de eles utilizarem hoje não são mais as corretas, né?! (PS4)

(...) dizem que o pajé, eles querem simplesmente uma coisa financeira! Querem o dinheiro daquela família! Como a família está desesperada porque a pessoa está doente, então, eles gastam as coisas com o pajé! (PS6)

Podemos observar que não há aqui uma compreensão mais ampla sobre o que é um pajé. Weigel e Lira (2011) argumentam a importância para a interação com esse ator social indígena de conhecer como ele se forma, qual sua relação com a natureza, a cosmologia, os seres vivos e os espíritos, suas responsabilidades e atribuições, sua forma de trabalho. 
Predomina entre os Akwẽ-Xerente a figura do pajé. Para tanto, compreender "o que é um pajé, que tipo de formação é necessário para tornar-se um pajé, qual a sua relação com a natureza, os astros, os seres vivos e os espíritos, como ele é formado, quais as suas responsabilidades, como ele trabalha, como se relaciona com os comunitários e com os não índios" fomos buscar no texto de Weigel e Lira (2011). Conforme expõe esses autores, a complexidade do trabalho do pajé transita entre a orientação espiritual e medicinal, além de agir para disseminar os conhecimentos e práticas culturais características de seu povo. Para eles o fracasso costuma até mesmo pô-los em risco de morte social ou física. Em muitos discursos de profissionais essa figura aparece como um adversário que tira o remédio correto, com práticas ultrapassadas, ou com interesses meramente financeiros. O que demonstra mais uma vez a superficialidade da formação antropológica dos profissionais que atuam na saúde indígena.

Como ressalta Lorenzo (2011) a formação extremamente biotecnicista dos profissionais de saúde não permite uma melhor assimilação dos saberes tradicionais, nem das práticas de autocuidado culturalmente mediadas, deixando-os às margens das experiências diárias dos profissionais de saúde.

Deve-se levar em conta promoção de ações de incentivo à mobilização e à reflexão comunitária dos povos indígenas, permitindo a criação de estratégias para a manutenção, atualização e fortalecimento dos sistemas médicos tradicionais (BRASIL, 2007:9). Pois segundo a atenção integral de saúde em populações indígenas, faz-se necessário uma estrutura capaz de dar suporte a todas as atividades de prevenção, promoção, tratamento de nível básico, média e alta complexidade, orientada pelos princípios e diretrizes do SUS, contemplando ainda a diversidade cultural, geográfica, histórica e política dos povos indígenas.

O relatório da primeira reunião sobre medicina tradicional produzido pela FUNASA (BRASIL, 2007), conceitua a medicina tradicional indígena como sistemas xamânicos oriundos de concepções cosmológicos específicos, que precisam ser conhecidos. Não há segundo ele, portanto, como dissociar o conjunto de saberes e práticas de saúde a demais instâncias da vida. Assim sendo, podemos concluir que quando as formas tradicionais de viver sofrem por circunstâncias externas como é o caso do povo Akwê-Xerente, tanto a efetividade quanto a crença nas formas tradicionais de cura podem sofrer fortes abalos. Assim seria preciso como recomenda o relatório trabalhar em um eixo que investigasse as 
relações do xamanismo em contextos de intermedicalidade, como o vivido por esse povo. Sendo necessário ações e projetos voltados para o conhecimento e o fortalecimento dos rituais e seus praticantes, absolutamente importantes na manutenção da saúde e do bem estar dos povos indígenas.

Ao abordar as questões culturais em torno da saúde e da oferta de atenção do sistema de saúde emergeriam também algumas visões da cultura indígena de um modo geral, algumas positivas e outras negativas, as quais agrupamos na sub-categoria: Elementos Positivos e

\section{Negativos vistos na cultura indígena.}

"o povo Xerente é diferente dos outros (...) do branco, do povo como nós! Assim: eles são muito amorosos! Por outra parte também, eles são muito exigentes! Ele gosta de você, mas ele exige de você!"'(PS 2).

E dentro da cultura deles também, eles têm outra coisa também que eles gostam (...) eles querem tentar manipular a gente! !’(PS 3).

As observações meramente empíricas trabalhadas obviamente a partir de valores da cultura não índia, demonstra a necessidade de espaços de discussão dentro dos projetos de capacitação para que o profissional possa problematizar suas percepções morais sobre as características culturais dos povos com os quais vão trabalhar. Seria interessante, que eles pudessem discutir com base em etnografias mais rigorosas essa percepção de que eles são "amorosos", "exigentes", "manipuladores". Podemos observar nestes discursos a valoração positiva relacionado à interpretação da cultura por parte dos profissionais de saúde, que segundo estes, conseguem reconhecer as diferenças existentes entre a sociedade ocidental e tradicional como observado no fragmento "o povo Xerente é diferente dos outros (...) do branco, do povo como nós!” (PS 2) Essa percepção cultural é imprescindível para o desenvolvimento dos serviços prestados uma vez que as especificidade culturais estão demarcadas no cotidiano dos Akwẽ-Xerente facilitando o diálogo entre os serviços e a demanda.

Para Athias e Machado, (2001:429) formação dos profissionais de saúde no país está voltada prioritariamente para a intervenção e atendimento individual da demanda espontânea, pautado pela ética profissional, o que muitas vezes dificulta a percepção mais ampla da 
necessidade de participação nos grupos sociais nos aspectos inerentes à atenção a saúde. Neste sentido, existe uma prática de organização de serviços de saúde que relega a segundo plano a participação social, perdendo-se assim a oportunidade de diálogo, por exemplo, entre a prática médica ocidental e a medicina tradicional, a qual pode contribuir para o desenvolvimento de um sistema local de saúde adequado à realidade dos povos indígenas.

Falar sobre cultura, é colocar em pauta uma serie de medidas singulares de percepções no atendimento e nos serviços prestados, para tanto, Woodward (2008:15) afirma que as "pessoas assumem suas posições de identidades e se identificam com elas a partir da inversão de posições que no discurso são identificados no nível psíquico”. Trata-se de uma dimensão que, juntamente com a simbologia e a razão social necessária para uma completa conceitualização de identidade. Todos esses elementos contribuem para explicação das identidades formadas e mantidas.

Obter a noção dos processos positivos e negativos de uma cultura singular é muitas vezes caminhar para a apreciação da identidade e da diferença como uma questão de produção significativa ao passo que, trata se de uma relação entre as diferenças culturais e não como uma questão de consenso, de diálogo ou comunicação, mas como uma questão que envolve, fundamentalmente as relações de poder (HALL, 2008).

Assim, podemos observar nos elementos positivos e negativos da cultura AkwẽXerente, apontando pelos profissionais da saúde que lidam no cotidiano desses Povos são demarcados pelas diferenças. Os pontos positivos, como já exposto anteriormente, tidos como a aceitação dos serviços prestados, os sentimentos de respeito e amorosidade bem como a confiança depositada nestes profissionais pelos indigenas, é um ponto significativo nos processo de fazer saúde nesta população tão singular. Já os pontos negativos apontados estão relacionados com a estrutura organizativa desta comunidade, particularmente a relação de poder entre homens e mulheres, como explicitado no discurso dos profissionais de saúde.

(...) na cultura indígena, a mulher, enquanto ela é virgem, ela tem um valor! Perdeu a virgindade, ela não tem valor! É muito discriminada! (...) a mulher não tem autoridade! Ela só baixa a cabeça!”(PS 2). 
Para Milhomem e Cruz (2010:26) que trabalharam com Construção da Identidade a partir da Percepção da Mulher Akwi, estes autores, fazem uma alusão ao debate acerca das relações de gênero no espaço do cotidiano indígena cujo discurso dominante sobre as relações de gênero é o da existência de igualdade e neutralidade de gênero. Outro fator importante de análise dessa relação está registrado no ritual de nominação, visto que na nominação masculina, os Akwẽ-Xerente promovem deslocamentos e reuniões de grupos de aldeias que durante o ritual, recompõem - se como uma só aldeia. Já no ritual de nominação feminina, apenas alguns segmentos dos grupos das aldeias, em função do princípio de pertencimento às classes de idade, é que se locomovem. Portanto, tem-se o seguinte esquema: PúblicoHomem- Nominação Masculina, e Privado - Mulher-Nominação Feminina. Neste processo organizativo, observa - se o paralelo entre a nominação masculina e feminina, sendo que os dois processos pertencem a duas Metades Patrilineares (MILHOMEM E CRUZ, 2010:27).

No entanto, no processo de contato com o não índio, os Akwẽ-Xerente abandonaram ou ressignificaram, gradativamente, alguns de seus costumes cerimoniais e incorporaram hábitos e transformações da cultura brasileira. Alguns ritos sociais foram preservados ao lado de novos costumes, criando-se um misto da cultura de origem (indígena) e da cultura importada (não indígena).

Não é possível, por exemplo, avaliar a validade como dado etnográfico dessa afirmação, quanto ao valor de gênero, fora de um contexto e pode ser decorrente simplesmente de um julgamento estigmatizante e ou esteriotipado.

Ao caminhar mais diretamente para as possibilidades de tratamento e prevenção do alcoolismo dirigido aos povos indígenas e mais especificamente ao povo Akwê- Xerente, três subcategorias puderam ser identificadas: O reconhecimento da "necessidade de políticas e programas específicos" foi mencionada por alguns profissionais, sem qualquer referência ao fato de já existir desde 2002 uma política específica para a saúde indígena. É claro, entretanto, que eles se referiam mais especificamente a programas de enfrentamento do alcoolismo.

"Eu penso que seria juntar todo mundo e pensar e criar uma política (...) política bem definida, clara. E onde todos... vários... pessoas, vários atores estivessem envolvidos não só pra instituir a política, mas também pra respeitar essa política. Então, teria que ter uma política pública”. (PS 1). 
Podemos concluir que existe uma grande fragilidade no campo das políticas publica para enfrentamento do álcool entre os povos indígenas, uma vez que nem a Política Nacional para a Saúde Integral dos Povos Indígenas, tem diretrizes específicas para a abordagem do problema, nem desenvolveu a partir dela programas específicos, nem a Política para a Atenção Integral a Usuários de Álcool e Outras Drogas porta diretrizes para abordagem em contextos de grande diversidade cultural. Pois se tratando de povos indigenas, cada um tem seu modo de beber, suas variações e suas crenças. Qualquer intervenção significativa deve perpassar o conhecimento de um grupo de profissionais, lideranças e gestores para uma eficiente e uma satisfatória compreensão e execução. Portanto, existe sim, uma necessidade de políticas e programas específicos para o enfrentamento do álcool entre os povos indígenas, e que precisarão serem adequadas ainda ao contexto de cada povo específico como o AkwẽXerente.

Ainda quanto à abordagem de enfrentamento do problema, foi também identificada uma "Necessidade de apoio aos profissionais". Os profissionais se sentem jogados naquele contexto sem formação específica sem apoio, sem ter espaços para discutir suas abordagens. Um dos profissionais deixa bem clara essa sensação de impotência do profissional da ponta do sistema.

"Querer só não resolve! Por exemplo: não adianta eu querer ou você querer ou alguém querer, né?! Tem que querer, mas tem que ter um respaldo, juntar forças e tal, né?! (...) e criar realmente uma política voltada para isso! Eu acho que, no momento, eu penso que não existe!”(PS 1).

É demonstrado pelo discurso dos profissionais de saúde que o fardo de se trabalhar sem estratégias de enfrentamento é para os profissionais, um grande desafio. $\mathrm{O}$ trecho que exemplifica essa carência técnica esta "essa situação, a saúde, por si só, é muito totalmente impotente, na minha visão, né?!"'(PS 1).Como refere Ferreira (2012), o caminho mais profícuo de se trabalhar a melhoria dos serviços prestados pelos profissionais de saúde seria necessário que índios, gestores do subsistema e representantes dos municípios e os profissionais de saúde se dispusessem ao estabelecimento de um diálogo que se inicie com o reconhecimento da existência de uma realidade diferenciada. 
Ainda, embora se perceba um risco de maior vulnerabilidade nas populações indígenas, o fato de a prática de saúde ser realizada no território indígena, em que as lideranças são estabelecidas de acordo com a cultura de cada Povo, esta decisão "leva os profissionais de saúde a uma posição mais horizontal com os usuários. Haja vista que a atuação das equipes de saúde junto à população indígena deve partir primeiramente do consentimento das comunidades" (FERREIRA, 2012:51).

Surge aqui também o reconhecimento da "Necessidade de atenção à saúde culturalmente adequada" que constituiu uma outra subcategoria de perspectivas enunciadas pelos colaboradores:

"Eu acho que ainda é um processo; ainda não acharam o caminho. De trabalhar com a população! (...) eu acho que falta ainda muito (...) é melhorar a relação, né! E definir melhor o papel de cada um (...)" (PS 7).

"a gente vê a diversidade cultural; a gente tem que saber lidar com isso; e até mesmo a questão das doenças, né?! (...) a questão de lidar com a saúde que é uma realidade totalmente diferente da cidade, do branco" (PS 5).

Os achados evidenciam uma fragilidade da oferta dos serviços prestados aos AkwẽXerente. Existe uma miopia relacionada às estruturas de base, de ponta, para o fazer saúde indígena. Especificamente em relação ao povo Akwê-Xerente é preciso o fortalecimento do Pólo base Tocantínia, a partir de uma unidade administrativa que dê conta do apoio logístico e às organizações das ações desenvolvidas.

Garnelo (2003) disserta acerca de alguns percalços administrativos, as relações conveniais vêm determinando o ritmo de trabalho das entidades de ponta "forçando-as ao cumprimento de programações, metas, prazos e orçamentos definidos em planos distritais que em nada se assemelham as suas rotinas administrativas prévias, ocasionado um estrangulamento na operacionalização dos serviços prestados”. Além disso, o “ônus político, decorrente de cortes no orçamento, atrasos no repasse de recursos, conflitos trabalhistas, dificuldades de referência e contra-referência, recai sobre a equipe de ponta, que é, para o usuário, a face visível das dificuldades da operacionalização do subsistema indígena". Como 
demostrado na fala "é preciso que tenha uma instituição que esteja disposta a conhecer a realidade, a respeitar os limites, né” (...) da gente” (PS 1).

O reconhecimento da baixa qualidade de atenção ofertada e baixa acessibilidade foram também reconhecidos e puderam ser agrupados na subcategoria "Necessidades de melhorias da qualidade e acesso aos cuidados de saúde":

“(...) a vontade de melhorar a qualidade, de dar à saúde indígena qualidade na assistência, sabe? Na assistência da qualidade é o que eu acho que esse é o grande desafio!” (PS 1).

"E como a comunidade é grande, né! São cinquenta e seis aldeias ai no município, né tem delas que tem um acesso difícil” (PS $4)$.

É evidenciada nas falas dos profissionais de saúde uma desarticulação do modelo de assistência prestada, como expresso nos fragmentos "na assistência da qualidade é o que eu acho que esse é o grande desafio!’ (PS 1). A qualidade e acesso devem atender às necessidades da população. Deve estar preparado para identificar o problema, avaliar, propor e acompanhar os indigenas.

Lidar com a temática "qualidade e acesso" é colocar em pauta as discursões de acesso e melhoria dos serviços, tema este que deve estar presente nas discursões populares, onde os próprios indigenas manifestem suas reais necessidades frente aos serviços ofertados. Como colocado por Ferreira (2012:118) "Essa situação pode ser revertida com a ocupação mais incisiva dos espaços de controle social pelos povos indígenas: eles devem exigir a consolidação desses espaços na qualidade de mecanismos de interlocução com os governos. Para isso, é necessário haver um maior envolvimento das lideranças tradicionais".

Apenas no discurso de um dos colaboradores foi possível encontrar algo que pudesse ser compreendido como uma atuação de prevenção, que nomeamos como subcategoria “Proposta de prevenção" exposta por meio do fragmento:

“A facilidade é arrumar alguma coisa pra ele (...) pra ele se ocupar! É a tal história: mente vazia, piscina de Satanás! Né?! Se ele é desocupado, você vai fazer o que? Mendiga” (PS 3). 
Ainda que aqui a proposta relacionada à ocupação não permite concluir por uma compreensão mais aprofundada da necessidade de restauração de formas tradicionais de vida, acesso à terra, etc. É importante, por sair do campo exclusivo de recuperação da saúde, em um exercício de buscar formas de evitar o alcoolismo, ainda que de forma simplista ligada exclusivamente à ocupação.

As propostas de intervenção são inúmeras, contudo a mais assertiva é quando todas as ações dos profissionais são reavaliadas de acordo com a cultura de cada Povo com que se trabalha. Essas ações de prevenção devem priorizar uma lógica diferenciada que é pautada pela permanente negociação entre os saberes ocidentais e tradicionais com relação à forma de organização e execução dos serviços de saúde. Isso é fundamental para evitar o acirramento de conflitos e a eficácia das estratégias utilizadas.

Segundo Ferreira (2012:64) a relação dos índios com os profissionais de saúde, mobiliza as ações de saúde mais assertivas com uma condução das ações e forças a uma reflexão ética mais sóbria. Quando isso não ocorre, presencia-se a repetição de práticas de saúde hegemônicas que ignoram os valores dos usuários e fazem surgir inúmeros conflitos na relação intercultural. 


\section{CONSIDERAÇÕES FINAIS.}

Partindo para as considerações finais, podemos elencar alguns pontos de discursão que são manobras essenciais para discursão: (a) ausência de políticas e programas funcionando na ponta para combate à dependência de álcool; (b) a insuficiência de apoio ao profissional, bem como de capacitação para o diálogo intercultural; (c) necessidade de garantir melhor qualidade geral à atenção em saúde indígena.

Ao longo da pesquisa percebe-se uma grande fragilidade de programas específicos ao combate ao uso abusivo da bebida alcoólica entre os Akwẽ-Xerente. Esta população, de acordo com a pesquisa realizada com os profissionais de saúde, está totalmente exposta e vulnerável ao consumo da bebida industrializada, obtida na cidade de Tocantínia pelo livre acesso a compra e a venda. Não havendo nenhuma intervenção profilática para conter o avanço dos desdobramentos ocasionados pelo uso abusivo da bebida alcoólica. Concluímos que há a necessidade de ações e estratégias focadas aos grupos mais vulneráveis, particularmente àqueles que estão expostos ao contato com a população ocidental. Ainda, precisa de um trabalho mais enfático no âmbito da conscientização por parte das lideranças indigenas, quanto aos riscos que seus estão expostos. Deve-se haver uma promoção de conhecimento mais aprofundado para a resolução entre Akwẽ-Xerente, do uso e abuso da bebida alcoólica.

A relação com os profissionais de saúde deve ser mais horizontal por parte do DSEI Tocantins, considerando que entre os Akwẽ-Xerente existe um número expressivo de indivíduos em risco aos problemas emanados do consumo abusivo a substância alcoólica. Observa-se também, a existência de um despreparo técnico visto junto à equipe multiprofissional que atuam entre os Akwẽ-Xerente em lidar com a problemática - álcool e seus efeitos nefastos em contexto de diversidade cultural.

Quanto à necessidade de um atendimento centrado na prevenção e no serviço especializado de combate ao uso indiscriminado da bebida alcoólica, considerando que no momento de realização desta pesquisa estão estagnados. Conclui-se que relação intercultural não pode ser apenas inserida nos discursos, ela deve priorizar o contexto multicultural e surgir com uma prática especializada de ações fiéis aos reais problemas da comunidade, prioritariamente as ações de intervenção ao uso abusivo da bebida alcoólica entre os AkwẽXerente. Para tanto, o serviço ofertado deve ser inserido de uma maneira a dar total suporte 
ao Pólo-base Tocantínia de lidar com o problema do álcool, inicialmente feito pela estruturação da equipe de saúde a fim da dar maior robustez aos serviços prestados. Portanto, faz-se necessário aprofundar a análise sobre a realização prática dos princípios obtidos nas falas e na prática dos profissionais de saúde.

Quanto aos cumprimentos dos objetivos desta pesquisa, podemos afirmar que foram alcançados por meio dos discursos dos profissionais de saúde.

- No campo das percepções dos profissionais de saúde sobre as causas e consequências do consumo e o abuso da bebida alcoólica entre os AkwẽXerente, podemos concluir que o indígena Akwẽ-Xerente está suscetível aos efeitos da bebida alcoólica e a causa do consumo abusivo esta no campo das Perdas das funções sociais laborais devido ao processo do contato intercultural com a sociedade ocidental atrelado a uma mudança de comportamento existente entre os próprios indigenas; Modificação do padrão de uso e facilidade de acesso pela aproximidade com a cultura ocidental em que as aldeias circunvizinhas à cidade de Tocantínia têm o maior número de indivíduos com problemas relacionados ao uso abusivo da bebida alcoólica; Inabilidade intrínseca do indígena em lidar com conflito sendo este um elemento psíquico que em muito contribui para o envolvimento com a substância alcoólica como fuga dos problemas encontrados nos espaços intra, extra familiares e intra e extra comunitários e como consequências Agressividade; Perda da função provedora; Reforço do preconceito e Doenças físicas.

- $\quad$ Em relação às percepções dos profissionais de saúde sobre a qualidade da atenção prestada para prevenção e terapêutica ao abuso de álcool e síndrome de dependência em suas unidades podemos concluir que não há, desde o momento de realização desta pesquisa, ações voltadas para inibir o uso abusivo da bebida alcoólica entre os Akwẽ-Xerente. Faz-se necessária a criação de ações multifacetárias que atendam a diversidade cultural dos indigenas Akwẽ-Xerente para o enfrentamento da problemática presente neste Povo. As falas dos profissionais de saúde são de total impotência frente problema.

- Quanto a avaliar da visão dos profissionais de saúde em relação ao Sistema de Saúde como um todo e políticas públicas dirigidas ao problema. Observamos que existe uma crítica construída no discurso dos profissionais na admissão do 
problema, contudo as estratégias de enfrentamento são incipientes. Ficando o serviço de assistência à saúde em total desassistência. Como saída apontada, uma eminente mudança nas posturas e nas condutas cristalizadas diante de problemas conhecidos (persistentes) que levarão a transformações da realidade hoje compreendida entre os Akwẽ-Xerente.

- A respeito da investigação como está construída a visão dos profissionais sobre o povo Akwẽ-Xerente no âmbito das relações interculturais. Observamos que o contato profissional propiciou entre os profissionais de saúde um reconhecimento adequado das relações interculturais. Esse reconhecimento é revestido de "respeito", "amorosidade" e "estreitamento" das relações de trabalho. E ainda, percebemos que o profissional embora "esgotado" pela alta demanda de serviço e a falta de instrumentos precisos para o desenvolvimento dos serviços; pelo numero insuficiente de profissionais existentes no Pólo-base Tocantínia; estes conseguem respeitar as diferenças culturais existentes nas relações de serviço.

Quanto aos limites deste estudo, sinalizamos que ele foi feito em uma só região, com um só povo e com um pequeno contingente de profissionais de saúde que implica na necessidade de estudos maiores para conclusões mais gerais. Podemos apontar ainda que estudos sobre uso e abuso da bebida alcoólica entre os Akwẽ-Xerente seria mais fidedigna se os sujeitos do estudo fossem os próprios indígenas.

Este estudo demonstrou na prática as dificuldades da atenção à saúde intercultural, a qual pode contribuir para o desenvolvimento de projetos de capacitação local dos profissionais de saúde, o fortalecimento do subsistema indígena de saúde bem como fornecer elementos que contribua para o engajamento das lideranças e dos conselhos indigenas atuantes entre os Akwẽ-Xerente. Este estudo demonstrou a fragilidade do Akwẽ-Xerente em lidar com o uso abusivo do álcool e a limitação das ações de serviços prestados pelo Subsistema Indígena de Saúde. 


\section{Referenciais}

AGUIAR, J . I. \& SOUZA, J. A., 1997. Prevalência de Alcoolismo na População Indígena da Nação Teréna do Complexo Sidrolândia-Colônia Dois Irmãos do Buriti. In: Ministério da Saúde: Anais da I Oficina Macrorregional de Estratégia, Prevenção e Controle das DST/AIDS para as Populações Indígenas das Regiões Sul, Sudeste e do Mato Grosso do Sul. Londrina.

AURELIANO, André Luís Procópio. MACHADO JR. Alcoolismo no contexto indígena brasileiro: mapeamento da bibliografia nacional. Revista de Antropologia - Ano 4 - Volume 5 - Maio de 2012.

AGUDELO, S. F., 1989. Violencia y/o Salud: Elementos Preliminares para Pensarlas y Actuar. Washington, DC: PAHO/OMS. (Mimeo.)

BAUER, M. \& ARTS, B. A Construção do corpus: um princípio para a coleta de dados qualitativos. In: BAUER, Martim W.; GASKELL, George. Pesquisa Qualitativa com texto, imagem e som - um manual prático. Editora Vozes: São Paulo, $7^{\mathrm{a}}$ edição, 2008.

BAUER, Martim W.; Gaskell, George. Pesquisa Qualitativa Com Texto, Imagem E Som: Um Manual Prático. Editora Vozes: São Paulo, $7^{\text {a }}$ Edição, 2008.

BAUMAN, Zygmunt. Modernidade Líquida. Tradução: Plínio Dentzien. Rio De Janeiro: Zahar, 2003. 258p

BAUMAN, Zigmunt. Globalização: As conseqüências humanas. Rio de Janeiro: Zahar, 1999.

. Identidade: Entrevista. (org.) A Benedetto Vecchi. Tradução Carlos Alberto

Medeiros. Rio De Janeiro: Jorge Zahar Ed., 2005.

BARTH, F. Grupos Étnicos E Suas Fronteiras. In: Poutignat, P. Teorias Da Etnicidade. Seguido De Grupos Étnicos E Suas Fronteiras De Fredrik Barth, Philippe Poutignat, Jocelyne Streiff-Fenard. Tradução De Elcio Fernandes. São Paulo: UNESP, 1998.

BASTOS, Francisco, BESTONI, Neilane; HACKER Mariana A. Consumo se Álcool e Drogas: Principais Achados de Pesquisa de Âmbito Nacional, Brasil 2005. Rev. Saúde Pública 2004; 42(Supl 1):109-17

BEDIN ZANATTA, Aline; GARGHETTI, Francine Cristine; LUCCA, Sérgio Roberto de. O centro de atenção psicossocial álcool e drogas sob a percepção do usuário. Revista Baiana de Saúde Pública, v. 36, n. 1, p. 225, 2012.

BERGER, P. L. \& Luckmann, T. A Construção Social Da Realidade. Petrópolis: Vozes, 1974

BÍBLIA SHEED/Editor Responsável Russell P. Cheio; Traduzida em Português Por João Ferreira De Almeida - 2. Ed. Ver. E Atual . No Brasil - São Paulo: Vida Nova; Brasília: Sociedade Bíblica Do Brasil, 1997.

BRASIL, Portaria N. ${ }^{\circ}$ 254/Gm, Em 31 De Janeiro De 2002. Ministério Da Saúde Secretaria De Políticas De Saúde Departamento De Atenção Básica Coordenação De Estratégias Para O 
Desenvolvimento e Gestão da Atenção Básica a Saúde/Secretaria De Políticas De Saúde/Coordenação Nacional de DST E AIDS, 2001. P. 83-97.

Ministério Da Saúde. Fundação Nacional De Saúde. Projeto Vigisus II. Coordenação Técnica. Área De Medicina Tradicional Indígena. Medicina Tradicional Indígena Em Contextos - Anais Da I Reunião De Monitoramento. Luciane Ouriques Ferreira E Patricia Silva Osório (Org.). Projeto Vigisus Ii/Funasa. Brasília: Fundação Nacional De Saúde, 2007.

DATASUS.Gov.Br. Disponível Em:

Http://Www.Datasus.Gov.Br/Cid10/V2008/Webhelp/F10_F19.Htm. Acessado em: 18 De Maio De 2014.

. DATASUS.Gov.Br. Disponível Em:

Http://Tabnet.Datasus.Gov.Br/Cgi/Tabcgi.Exe?Sim/Cnv/Obt10uf.Def. Acessado em: 18 De Maio De 2014.

Fundação Nacional De Saúde. Lei Arouca: A Funasa Nos 10 Anos De Saúde Indígena / Fundação Nacional De Saúde. - Brasília: Funasa, 2009.

. Lei N. 6001, De 19 De Dezembro De 1973. Dispõe Sobre O Estatuto Do Índio. Disponível Em: < Http://Www.Planalto.Gov.Br/Ccivil 03/Leis/L6001.Htm>. Acesso Em: 15 Set. 2013.

BUCHER, R. Prevenção Ao Uso Indevido De Drogas. $2^{\mathrm{a}}$ Ed. Brasília: Editora Universidade De Brasília, 1991.

BUCHER, R. Drogas e drogadição no Brasil. Porto Alegre: Artes Médicas, 1992.

BOURDIEU, P. (2007). A economia das trocas simbólicas (5a ed.). São Paulo: Perspectiva.

CABRAL, L. do R.; FARATE, C. M. da C.; DUARTE, J. C. Representações Sociais sobre o Álcool em Estudantes do Ensino Superior. Revista Referencia. II. ${ }^{a}$ Série - $n^{o}$ 4- Jun. 2007.

CALDEIRA, E. B. A Constituição Discursiva de Identidades Xerentes no Espaço Escolar Multicultural. Dissertação apresentada ao Programa de Pós-Graduação em Linguística, Depto. de Linguística, Línguas Clássicas e Vernácula, Instituto de Letras, Universidade de Brasília 2011.

CARDOSO, L. G. V.; MELO, A. P. S.; CESAR, C. C. Prevalência do consumo moderado e excessivo de álcool e fatores associados entre residentes de Comunidades Quilombolas de Vitória da Conquista, Bahia, Brasil. Ciência \& Saúde Coletiva, 20(3):809-820, 2015

CARDOSO, Luiz Gustavo Vieira; MELO, Ana Paula Souto and CESAR, Cibele Comini.Prevalência do consumo moderado e excessivo de álcool e fatores associados entre residentes de Comunidades Quilombolas de Vitória da Conquista, Bahia, Brasil. Ciênc. saúde coletiva [online]. 2015, vol.20, n.3 [cited 2015-11-30], pp. 809-820

CARDOSO, Luciana Roberta Donola, MALBERGIER, André, FIGUEIREDO, Tathiana Fernandes Biscuola. O Consumo De Álcool Como Fator de Risco para a Transmissão das DSTS/HIV/AIDS. In: Rev. Psiq. Clín 35, Supl 1; 70-75, 2008. 
CARVALHO, Marilia Sá; SOUZA-SANTO, Reinaldo. Análise de Dados Espaciais Em Saúde Pública: Métodos, Problemas, Perspectivas. Cad. Saúde Pública, Rio De Janeiro, 21(2):361-378, Mar-Abr, 2005.

CASCUDO, L. C. Prelúdio Da Cachaça: Etnografia, História E Sociologia Da Aguardente No Brasil. Rio De Janeiro: Instituto Do Açúcar E Do Álcool, 1968.

CEBRID - Centro Brasileiro De Informações Sobre Drogas Psicotrópicas. Disponível Em: < Http://Www.Cebrid.Epm.Br/Folhetos/Alcool_Htm\#Gerais>. Acessado Em: 01/04/2014.

CISA - Centro De Informações Sobre Saúde E Álcool. Disponível Em: < Http://Www.Cisa.Org.Br/Artigo/235/Alcool-Origem-Composicao.Php>. Acessado Em: $2603 / 2014$.

CLONINGER Cr. Neurogenetic Adaptative Mechanism In Alcoholism. Science 1987; 236:410-5.

COIMBRA, C. E. A., Jr., SANTOS, R. V., \& ESCOBAR, A. L. (Eds.). (2003).

Epidemiologia E Saúde Dos Povos Indígenas No Brasil. Rio De Janeiro, RJ: Fundação Oswaldo Cruz/Abrasco. 260 p. ISBN: 85-7541-022-9. Available from SciELO Books <http://books.scielo.org>.

COLOMA, C. (2001). Processo De Alcoolização No Contexto Das Nações Indígenas. In Anais Do Seminário Sobre Alcoolismo E DST/AIDS Entre Os Povos Indígenas (Pp. 127148). Brasília, DF: Ministério Da Saúde.

COSTA, Juvenal S Dias Da; SILVEIRA, Mariângela F; GAZALLEA,Fernando K; OLIVEIRA; Sandro S, HALLALA; Pedro C, MENEZES, Ana Maria B, GIGANTEA, Denise P, OLINTOC; Maria T A; MACEDO, Silvia. Consumo Abusivo De Álcool E Fatores Associados: Estudo De Base Populacional. In: Saúde Pública 2004; 38(2)284-91.

DSM-IV-TR - Manual Diagnóstico e Estatístico De Transtornos Mentais. Trad. Cláudia Dornelles. 4 Ed. Rev. Porto Alegre, Art med, 2002.

DENZIN, N. K.; LINCOLN, Y. S. (org). O planejamento da pesquisa qualitativa: teorias e abordagens. Porto Alegre: Artmed, 2006.

EAGLETON, Terry, 1943 - A Ideia De Cultura/Terry Eagleton; Tradução Sandra Castello Branco; Revisão Cezar Mortari. - São Paulo: Editora UNESP, P. 205, 2005.

Ideologia: Uma Introdução à Cultura. Tradução De Silavana Vieira E Luís Carlos

Borges. São Paulo: Editora UNESP: Editora Bomtempo, 1997, P. 193-195]

EDWARD, G. - Problems And Dependence: The History Of Two Dimensions. In: Lader, M.; Edward, G And Drummond, D.C. Eds. - Nature Of Alcool Ande Drug Related Problems. New York; Oxford University Press, 1992, 1-14.

FERNANDES, João Azevedo. Cauinagens e bebedeiras: os índios e o álcool na história do Brasil. Revista Anthropológicas, v. 13, n. 2, 2011. 
FERREIRA MJ. Saúde no trabalho. São Paulo(SP): Roca; 2000.

FERREIRA, Luciana Benevides (2012). O Controle Social No Subsistema De Atenção À Saúde Indígena: Uma Reflexão Bioética (Dissertação). Universidade De Brasília Faculdade De Ciências Da Saúde Programa De Pós-Graduação Em Bioética

FERNANDES, J.A. Caiunagens e Bebedeiras: os índios e o álcool na história do Brasil. Revista Anthropológicas, ano 6, volume 13 (2): 39-59. 2002.

FERREIRA, Rogério. Bases Epistemológicas Akwẽ-Xerente E Apyãwa: Reflexões Sobre A Educação De Jovens E Adultos Em Terras Indígenas. Debates Em Educação Científica E Tecnológica, Issn 2179-6955, V. 01, No 1, P. 07-13, 2011.

ILIZOLA, Carmen Lúcia Alves et al . Compreendendo o alcoolismo na família. Esc. Anna Nery, Rio de Janeiro, v. 10, n. 4, p. 660-670, dez. 2006.

FLICK, Uwe. Desenho Da Pesquisa Qualitativa. Porto Alegre: Artmed, 2009.

FORTNEY J, MUKHERJEE S, CURRAN G, FORTNEY S, HAN X, BOOTH BM. Factors associated with perceived stigma for alcohol use and treatment among at-risk drinkers. Behav Health Serv Res. 2005;31(4):418-29. . Uma Introdução À Pesquisa Qualitativa. 2. Ed. Porto Alegre: Artmed, 2004.

FUNAI. Fundação Nacional do Índio. Disponivel em http://www.funai.gov.br/index.php/indios-no-brasil/quem-sao. Acessado em 16.04.2016.

GADAMER Hg. Verdade E Método. Tradução De Flávio Paulo Meurer. $3^{\text {a }}$ Ed. Petrópolis: Vozes;1999.

GAMA, Adriana Ferreira; SANTOS, Aline Renée Benigno dos. Teoria Das Representações Sociais: Uma Análise Crítica Da Comunicação De Massa E Da Mídia.In: Revista Eletrônica Temática: Ano Vi, N. 10 - Outubro/2010.

GALVÃO, Eduardo. Estudos sobre a aculturação dos grupos indígenas do Brasil. Revista de antropologia, v. 5, n. 1, p. 67-74, 1957.

GARNELO L. Poder, hierarquia e reciprocidade: saúde e harmonia entre os Baniwa do Alto Rio Negro. Rio de Janeiro: Editora Fiocruz; 2003. (Coleção Saúde dos Povos Indígenas).

GRANDO, Beleni Saléte et al. Corpo e educação: as relações interculturais nas práticas corporais Bororo em Meruri-MT. 2004.

GEERTZ, Clifford. A Interpretação Das Culturas. São Paulo: Ltc, 2003.

GEERTZ, Clifford. Uma descrição densa: por uma teoria interpretativa da cultura. In: A interpretação das culturas. Rio de Janeiro: Zahar, 1978.

GIDDENS, Anthony. As Consequências Da Modernidade. São Paulo: Editora UNESP, 1991. 
GIRALDIN, Odair. Escola Na Aldeia E Professor Indígena Na Universidade: Reflexões Sobre Formação E Prática Docente Xerente. R. Pós Ci. Soc. V.7, N.14, Jul./Dez. 2010.

GOFFMAN, E. (1978). Estigma: notas sobre a manipulação da identidade deteriorada (2a ed.). Rio de Janeiro: Zahar

GOFFAMAN, Erving. A Representação Do E Na Vida Cotidiana: Tradução Maria Célia Santos Raposo. 15ª Ed. - Petrópolis, Vozes, 2008.

GUEDES, Ronner Costa; FREITAS, Ana Paula Fragoso de; VASCONCELOS, Tatiana Cristina; CERQUEIRA, Gilberto Santos; ROCHA, Nayrton Flavio Moura; PINTO, Rogélia Herculano Pinto. Consumo de Alcool em uma Comunidade do Cariri Cearense. Revista Intertox de Toxicologia, Risco Ambiental e Sociedade, vol.3, n³, out, 2010.

GUIMARÃES, L. A. M., \& GRUBITS, S. (2007). Alcoolismo E Violência Em Etnias Indígenas: Uma Visão Crítica Da Situação Brasileira. Psicologia E Sociedade, 19(1), 41-51. Psicologia \& Sociedade; 19 (1): 45-51; jan/abr. 2007.

HALL, Stuart. A Identidade Cultural Na Pós-Modernidade. $4^{\mathrm{a}}$ Ed., Rio De Janeiro: Dp\&A, 2000 .

HEIDEGGER M. Ser E Tempo. Petrópolis: Vozes;1988.

HEIDEGGER M. Editora Abril: São Paulo;1980. (Coleção Os Pensadores).

HELMAN C. Cultura, Saúde E Doença. 4ª Ed. Porto Alegre: Editora Artes Médicas; 2003.

II LEVANTAMENTO DOMICILIAR SOBRE O USO DE DROGAS PSICOTRÓPICAS NO BRASIL : Estudo Envolvendo As 108 Maiores Cidades Do País : 2005 / E. A. Carlini (Supervisão) [Et. Al.], -- São Paulo : Cebrid - Centro Brasileiro De Informação Sobre Drogas Psicotrópicas: Unifesp - Universidade Federal De São Paulo, 2006.

JACÓ-VILELA, Am., SATO, L.,( Orgs). Diálogos Em Psicologia Social. Rio De Janeiro: Centro Edelstein De Pesquisas Sociais, 2012. In: Pedrinho Guareschi. O Que É Mesmo Psicologia Social? Uma Perspectiva Crítica De Sua História E Seu Estado Hoje Pedrinho Guareschi : Pontifícia Universidade Católica Do Rio Grande Do Sul.

JUNIOR, Stanislau Bogusz; KETZER, Daiane Cristina Mertins; ANDRADES , Raquel Gubert; GOBO, Lucieli; BACARIN, Anagilda. Composição Química Da Cachaça Produzida Na Região noroeste do Rio Grande Do Sul, Brasil. Ciênc. Tecnol. Aliment., Campinas, 26(4): 793-798, Out.-Dez. 2006.

JÚNIOR, João Roberto Bort. SOUZA, Maximiliano Loiola Ponte de (org.). 2013. Processos de Alcoolização Indígena no Brasil: perspectivas plurais. Rio de Janeiro: Editora FIOCRUZ. 252 p. CAMPOS-Revista de Antropologia Social, v. 15, n. 1, 2014.

KOIFMAN, Sergio . Geração e transmissão da energia elétrica: impacto sobre os povos indígenas no Brasil. Cad. Saúde Pública, Rio de Janeiro, 17(2):413-423, mar-abr, 2001. 
KUNITZ, S. J. Life-Couse Observations Of Alcohol Use Among Navajo Indians: Natural History Or Careers. Medical Anthopology Quarterly, 20 (3): 279-296, 2006.

LACERDA, A. L. T. (1999). Alcoolismo E Trabalho. In L. A. M. Guimarães \& S. Grubits. Saúde Mental E Trabalho: Vol. 1 (Pp. 04-12). São Paulo, SP: Casa Do Psicólogo.

LACERDA, Gustavo Biscaia De. Elementos Estáticos Da Teoria Política De Augusto Comte: As Pátrias E O Poder Temporal. Rev. Sociol. Polít., Curitiba, 23, P. 63-78, Nov. 2004

LARAIA, Roque De Barros. Cultura: Um Conceito Antropológico. 17. Ed. Rio De Janeiro: Jorge Zahar, 2004

LARANJEIRA. Ronaldo; ROMANO, Marcos. Consenso Brasileiro Sobre Políticas Públicas Do Álcool. Políticas Públicas Do Álcool / Laranjeira R \& Romano M Rev. Bras. Psiquiatra; 26(Supl I):68-77, 2004.

LARANJEIRA R, PINSKY I, ZALESKI M, Caetano R. I Levantamento Nacional Sobre Os Padrões De Consumo De Álcool Na População Brasileira. Brasília: Secretaria Nacional Antidrogas; 2007.

LANGDON, Esther Jean .Representações De Doença E Itinerário Terapêutico Dos Siona Da Amazônia Colombiana. In: Santos, Ricardo V. (Org.) Saúde E Povos Indígenas/Organizado Por Ricardo V. Santos, Carlos E. A. Coimbra Jr. — Rio De Janeiro: Fiocruz, 1994. 251 P.

LANGDON, E. J. (2001). O Que Beber, Como Beber E Quando Beber: O Contexto Sociocultural No Alcoolismo Entre As Populações Indígenas. In Anais Do Seminário Sobre Alcoolismo DST/AIDS Entre Os Povos Indígenas (Pp. 83-97). Brasília, DF: Ministério Da Saúde.

LANGDON Esther Jean. O Abuso De Álcool Entre Os Povos Indígenas No Brasil: Uma Avaliação Comparativa. Tellus, Ano 5, N. 8/9, Abr./Out. 2005.

LAPLANTINE, François. Aprendendo Antropologia/François Laplantine : Tradução MarieAgnès Chauvel; Prefácio Maria Isaura Pereira Queiroz. - São Paulo:Brasiliense, 2007.

LEME, Maria Alice S. V. O Impacto Da Teoria Das Representações Sociais. In: Spink, Mary Jane P. (Org.), O Conhecimento Do Cotidiano: As Representações Sociais Na Perspectiva Da Psicologia Social. São Paulo: Brasiliense, 1995.

LORENZO,Cláudio Fortes Garcia. Desafios para uma bioética clínica interétnica: reflexões a partir da política nacional de saúde indígena. Rev. bioét (Impr.) 2011; 19(2): 329 - 42

LUCIANO - Brasília: Ministério Da Educação, Secretaria De Educação Continuada, Alfabetização E Diversidade; Laced/Museu Nacional, 2006.

MAGALHÃES, Edward Dias (Org.). Legislações Indigenistas Brasileiras E Normas Correlatas 3. Ed. - Brasília: FUNAИCgdoc, 2005. 700P.

MALTA, D. C.; SILVA JR. , J. B. O Plano de Ações Estratégicas para o Enfrentamento 
das Doenças Crônicas Não Transmissíveis no Brasil e a definição das metas globais para o enfrentamento dessas doenças até 2025: uma revisão. Epidemiol. Serv. Saúde, Brasília, 22(1):151-164, jan-mar 2013.

MARQUES, Ana Cecília Petta Roselli. O Uso Do Álcool E A Evolução Do Conceito De Dependência De Álcool E Outras Drogas E Tratamento. In: Revista Imesc No 3, 2001. Pp. 73-86.

MASCARENHAS, Márcio Dênis Medeiros; MALTA, Deborah Carvalho; SILVA, Marta Maria Alves Da; CARVALHO, Cynthia Gazal; MONTEIRO, Rosane Aparecida; NETO, Otaliba Libânio de Morais. Consumo De Álcool Entre Vitimas De Acidentes E Violências Atendidas Em Serviços De Emergência No Brasil, 2006 e 2007. Ciência \& Saúde Coletiva, 14(5):1789-1796, 2009.

MATHEW, V.M. Alcoholism In Biblical Profhecy Alcohol., 27:1 89-90, 1992.

MELO, Valéria M. C. Diversidade, Meio Ambiente E Educação: Uma Reflexão A Partir Da Sociedade Xerente. 2010. Dissertação (Mestrado em Ciências do Ambiente) - Universidade Federal do Tocantins, Palmas. 2010.

MELONI Jn; LARANJEIRA R (2004). Custo Social e de Saúde do Consumo do Álcool. Revista Brasileira Psiquiátrica, 26 (Supl. I):7-10.

MILHOMEM, Maria Santana Ferreira dos Santos; CRUZ, Maria Helena Santana. VOZES XERENTE: GÊNERO E CONSTRUÇÃO DA IDENTIDADE A PARTIR DA PERCEPÇÃO DA MULHER AKWI. Itabaiana: GEPIADDE, Ano 4, Volume 8 | jul-dez de 2010

MENÉNDEZ, Eduardo L. In: Processos De Alcoolização Indígena No Brasil: Perspectivas Plurais. Maximiliano Loiola Pontes De Souza (Org.) - Rio De Janeiro: Editora Fiocruz, 2013.

MENÉNDEZ, E. L. El Processo De Alcoholización: Revisión Crítica De La Produccion Socioantropológica, Histórica Y Biomédica Em América Latina. Revista Centro americana De Ciências De La Salud, 22: 61-94, 1982.

MINAYO, M. C. S. O conceito de representações sociais dentro da sociologia clássica. In: GUARECHI, Pedrinho A. e JOVCHELOVITCH, Sandra. Textos em representações Sociais. Petrópolis - RJ: Vozes, $1994^{\mathrm{a}}$

MINAYO, MC de S. et al. A violência social sob a perspectiva da saúde pública. Cadernos de saúde pública, v. 10, n. 1, p. 7-18, 1994b.

MINAYO, M. C. de S. e SOUZA, E. R. de: 'Violência e saúde como um campo interdisciplinar e de ação coletiva'. História, Ciências, Saúde — Manguinhos, IV(3): 513-531, nov. 1997-fev. 1998

MINAYO, M. C. S. O Desafio Do Conhecimento: Pesquisa Qualitativa Em Saúde. São Paulo: Hucitec/Abrasco; 1999. P. 6-19.

MINAYO, M. C. S. Pesquisa Social. Teoria, método e criatividade. 18ed. Petrópolis: Vozes, 2001. 
MINAYO, M. C. S.; DESLANDES, S. F. (org). Caminhos do pensamento: epistemologia e método. Rio de Janeiro: Editora FIOCRUZ, 2003. p. 83-107.

MONTEIRO, John Manuel. O Desafio Da História Indígena No Brasil. In: A Temática Indígena Na Escola: Novos Subsídios Para Professores De $1^{\circ}$ e $2^{\circ}$ Graus /Org. Aracy Lopes Da Silva E Luís Donizete Benzi Grupioni — Brasília, MEC/Mar/UNESCO, 1995.

MOTA, L. T., 1998. O Aço, a Cruze a Terra: índios e Brancos no Paraná Provincial (18531889). Tese de Doutorado, Botucatu: Programa de Pós-Graduação em História, Universidade Estadual Paulista.

MOTA, L.A. A dádiva da sobriedade: a ajuda mútua nos grupos de alcoólicos anônimos. São Paulo: Paulus, 2004.

NATHAN Pe. Behaviour Theory And Behavioural Theories Of Alcoholics. In: Galenter Recent Development In Alcoholism. New York: Plenum; 1983.

NEVES, Delma Pessanha. Alcoolismo: Acusação Ou Diagnóstico?. Cad. Saúde Pública, Rio De Janeiro, 20(1):7-36, Jan-Fev, 2004.

NIEWIADOMSKI, C. (2004). Violências e Alcoolismo: Abordagem Biográfica em Alcoologia e Hermenêutica do Sujeito. Psicologia Em Estudo, 9(3), 331- 341.

NICHTER, M., 1989. Anthropology and International Health: South Asian Case Studies. Dordrechet:Kluwer Publications.

NIMUENDAJU, Curt. The Šerente. Los Angeles: The Southwest Museum, 1942.

OLIVEIRA, João Pacheco De. Muita Terra Para Pouco Índio? Uma Introdução (Critica) Ao Indigenismo E A Atualização Do Preconceito. In: A Temática Indígena Na Escola: Novos Subsídios Para Professores De $1^{\circ}$ E $2^{\circ}$ Graus /Org. Aracy Lopes Da Silva E Luís Donizete Benzi Grupioni - Brasília, MEC/UNESCO, 1995.

OLIVEIRA, R. C. C. (2009). Representações Sociais Sobre A Situação De Vida, Saúde E Doença Na Concepção Indígena Potiguara. Dissertação De Mestrado, Universidade Federal Da Paraíba, João Pessoa, PB.

OLIVEIRA-REIS. F. C. (2001). Aspectos Do Contato E Formas Socioculturais Da Sociedade Akwë-Xerente (Jê). Departamento De Antropologia Da UnB. (Dissertação De Mestrado).

OLIVEIRA, M., 2000a. Alcoolismo entre os Kaingáng: Do sagrado e lúdico à dependência. In: Seminário sobre Alcoolismo e DST/AIDS entre os Povos Indígenas, Anais, pp. 99-125, Brasília: Secretaria de Políticas de Saúde, Ministério da Saúde.

OPAS. ORGANIZAÇÃO PAN-AMERICANA DA SAÚDE/Organização Mundial Da Saúde (2001). Relatório Sobre A Saúde No Mundo. São Paulo: Gráfica Brasil. 
OTENIO, Cristiane Corsini Medeiros. (2007). Representações Do Trabalho Multiprofissional Em Um Serviço Público De Saúde Municipal. Programa De Mestrado Em Saúde Coletiva, Da Universidade Estadual De Londrina.

PAULSON Re Women's Suffrage And Prohibition: A Comparative Study Of Equality And Social Control. Glenview, Il: Scott, Foresman And Company; 1973.

PECHANSKY, Flavio, Szobot, MACIEL, Claudia; SCIVOLETTO, Sandra. Uso De Álcool Entre Adolescentes: Conceitos, Características Epidemiológicas E Fatores Etiopatogênicos. Rev. Bras. Psiquiatra 2004; 26(Supl I):14-17

PEREIRA, P.P.S.; OTT, A.M.T. The process of development of alcoholism among the Tenharim people in villages along the Marmelos river, state of Amazonas. Interface Comunic., Saude, Educ., v.16, n.43, p.957-66, out./dez. 2012.

PIEROBON M, Barak M, HAZRATI S, JACOBSEN Kh. Alcohol Consumption And Violence Among Argentine Adolescents. J Pediatr (Rio J). 2013;89:100-106

PILlON Sc, Luis Mav. Modelos Explicativos Para O Uso De Álcool E Drogas E A Prática Da Enfermagem. Rev. Latino-Am Enfermagem 2004 Julho-Agosto; 12(4):676-82.

PINHEIRO, Paulo C.; Leal, Murilo C. E Araújo, Denilson A. De. Origem, Produção E Composição Química Da Cachaça. In: Química E Sociedade. N. 18, Nov.2003.

PINSKY, Ilana, JUNDI, SAMI A R J E. O Impacto Da Publicidade De Bebidas Alcoólicas Sobre O Consumo Entre Jovens: Revisão da literatura Internacional. Rev. Bras. Psiquiatra. 2008;30(4):362-74.

POUTIGNAT, P. Teorias Da Etnicidade. Seguido De Grupos Étnicos E Suas Fronteiras De Fredrik Barth, Philippe Poutignat, Jocelyne Streiff-Fenard. Tradução De Elcio Fernandes. São Paulo: UNESP, 1998.

QUILES, M. (2001). Mansidão de fogo - Aspectos etnopsicológicos do comportamento alcoólico entre os Bororo. In Anais do Seminário Sobre Alcoolismo e DST/AIDS entre os Povos Indígenas (pp. 166-179). Brasília, DF: Ministério da Saúde.

REESINK, Edwin In: Medicina Tradicional E Medicina Ocidental Na Amazônia; Organizado Por Dominiqui Buchillet. - Belém, Mpeg/CNPqSctPCUep, 1991.

RODRIGUES, Aroldo. 1993. Psicologia Social Para Principiantes: Estudo De Interação Humana / Aroldo Rodrigues - 14. Ed. - Petrópolis, RJ: Vozes, 2012.

RONZANI, Telmo Mota et al. Estigma social sobre o uso de álcool. Jornal brasileiro de psiquiatria, v. 59, n. 4, p. 326-332, 2010.

SÁ, Celso Pereira. Sobre o pensamento social e sua gênese: algumas impressões. In:Teoria das representações sociais: 50 anos/Angela Maria de Oliveira Almeida, Maria de Fátima Souza Santos, Zeide Araújo Trindade, organizadores. - Brasília:Technopolitik, 2011. 
SANTOS, Gerson dos. O Índio Brasileiro: O Que Você Precisa Saber Sobre Os Povos Indígenas No Brasil De Hoje /SANTOS, Ricardo V. (Org.) Saúde E Povos

Indígenas/Organizado Por Ricardo V. Santos, Carlos E. A. Coimbra Jr. — Rio De Janeiro: Fiocruz, 1994. 251 P. 2001.

SANTANA, M. G.; ERDMAN, A. L. Crenças em saúde: uma abordagem cultural. Cogitare Enfermagem. v. 5, n. 2, p. 7-14, jul./dez. 2000.

SAWAIA, B. B. (1995). Psicologia Social: aspectos epistemológicos e éticos. In S. T. M. Lane, \& B. B. Sawaia (orgs.), Novas veredas da psicologia social (pp.45-53). São Paulo: EDUC/Brasiliense.

SIFUENTES, T. R. (2007). Mulheres Indígenas Xerentes: Narrativas Culturais E Construção Dialógica Da Identidade. Programa De Pós Graduação Em Psicologia Da Universidade De Brasília - UnB (Dissertação De Mestrado).

SILVA, Cleuber Alves da. Estudos Indígenas: Comparações, Interpretações e Política/ Renato Athias, Regna Pahim Pinto (Organizadores). - São Paulo : Contextos, 2008. In: Silva, Cleuber Alves da. Interpretando Mundos: Contatos Entre Os Akwen E Os Conquistadores Luso-Brasileiros Em Goiás (1749-1811).

SILVA, Reijane Pinheiro; SOUSA, Apoliana Ribeiro de. "Alcoolismo e uso do álcool entre os Akwen Xerente do Tocantins: a perspectiva indígena". RBSE - Revista Brasileira de Sociologia da Emoção, v. 14, n. 42, p. 109-120, dez de 2015.

SILVA, Lux Vidal Aracy Lopes Da. O Sistema De Objetos Nas Sociedades Indígenas: Arte E Cultura Material. A Temática Indígena Na Escola: Novos Subsídios Para Professores De $1^{o}$ e $2^{\circ}$ Graus /Org. Aracy Lopes Da Silva E Luís Donizete Benzi Grupioni - Brasília, MEC/Mari/UNESCO, 1995.

SILVA L. V. E. R.; MALBERGIER A.; STEMPLIUK V. de A.; ANDRADE A. G. de.Consumo de álcool e drogas por universitários. Rev. Saúde de Pública, São Paulo 40(2):280-8, 2006a.

SILVA, LVE, RUEDA et al. Fatores associados ao consumo de álcool e drogas entre estudantes universitários. Rev. Saúde Pública, São Paulo, v. 40, n. 2, abr. p280-288 2006 b.

SILVEIRA, P. .Da; MARTINS, L.F.; SOARES, R.G.; GOMIDE, H.; RONZANI.T.M. Revisão Sistemática Da Literatura Sobre Estigma Social E Alcoolismo. Estudos De Psicologia, 16(2), Maio-Agosto/2011, 131-138.

SILVERMAN, D. Interpretação De Dados Qualitativos: Métodos Para Análise De Entrevistas, Textos E Interações. 3 Ed. Porto Alegre: Artes Médicas, 2009. 376 P.

SCHOROEDER, Ivo (2006). Política E Parentesco Nos Xerentes. Apresentada No Programa De Pós Graduação Em Antropologia Social, Do Departamento De Antropologia Da Faculdade De Filosofia, Letras E Ciências Sociais Humanas Da Universidade De São Paulo.

SCHÜTZ A. The Phenomenology Of The Social World. Translation G. Walsh And F. Lehnert. Evanston, Il: Northwestern University Press; 1967. 
SOUZA, J. A. De; OLIVEIRA, M. De; KOHATSU, M. O Uso De Bebidas Alcoólicas Nas Sociedades Indígenas: Algumas Reflexões Sobre Os Kaingáng Da Bacia Do Rio Tibagi, Paraná. In: Coimbra Jr., Cea., Santos, Rev. And Escobar, Al., Orgs. Epidemiologia E Saúde Dos Povos Indígenas No Brasil [Online]. Rio De Janeiro: Editora Fiocruz; Rio De Janeiro: Abrasco, 2005. 260 P. Isbn: 85-7541-022-9. Available From Scielo Books <Http://Books.Scielo.Org>.

SOUZA. Liliane Cunha De. Remédios Do Mato E Remédios De Farmácia: Relações Entre O Sistema Médico Fulni-Ô E O Sistema Oficial De Saúde. In: Brasil. Ministério Da Saúde. Fundação Nacional De Saúde. Projeto Vigisus Ii. Coordenação Técnica. Área De Medicina Tradicional Indígena. Medicina Tradicional Indígena Em Contextos - Anais Da I Reunião De Monitoramento. Luciane Ouriques Ferreira E Patrícia Silva Osório (Org.). Projeto Vigisus II/Funasa. Brasília: Fundação Nacional De Saúde, 2007.

SOUZA, M.; GARNELO, L. Desconstruindo O Alcoolismo: Notas A Partir Da Construção Do Objeto De Pesquisa No Contexto Da Saúde Indígena. Revista Latino Americana De Psicopatologia Fundamental. Vol. Ix N.2 P.279-292, 2006.

SOUZA, M. GARNELO, L. (2007). Quando, Como E O Que Se Bebe: O Processo De Alcoolização Entre Populações Indígenas Do Alto Do Rio Negro. Cadernos De Saúde Pública, 23(7), 1640-1648.

SOUZA, M. L. P. (2005, Jan.). Vulnerabilidade A Dependência Ao Álcool Em Paciente Indígena: Relato De Caso. Psychiatry On-Line Brazil, 10.

SOUZA, Maximiliano Loiola Ponte. Comércio de "álcool de farmácia" no município de São Gabriel da Cachoeira, Amazonas, Brasil: uma questão de saúde pública. Rev Bras Psiquiatr. 2007;29(4):380-5

SOUZA, Manoel Nascimento De; BARBOSA, Erivaldo Moreira. Direitos Indígenas Fundamentais E Sua Tutela Na Ordem Jurídica Brasileira. In: Âmbito Jurídico, Rio Grande, Xiv, N. 85, Fev 2011. Disponível Em: <Http://Www.Ambito-

Juridico.Com.Br/Site/?N_Link=Revista_Artigos_Leitura\&Artigo_Id=8978\&Revista_Caderno =9>. Acesso Em Maio 2014.

SOUZA, J . A. \& AGUIAR, J . I., 2000. Alcoolismo em população Teréna no Estado do Mato Grosso do Sul - impacto da sociedade envolvente. In: Seminário sobre Alcoolismo e DST/AIDS entre os Povos Indígenas, Anais, pp. 149-165, Brasília: Secretaria de Políticas de Saúde, Ministério da Saúde.

THE WORLD HEALTH REPORT, 2002. Reducing Risks, Promoting Healthy Life. World Health Organization.

THOMPSON, J. Ideologia E Cultura Moderna: Teoria Social Crítica Na Era Dos Meios De Comunicação De Massa. Tradução De Grupo De Estudos Sobre Ideologia, Comunicação E Representações Sociais Da Pós-Graduação Do Instituto De Psicologia Da Pucrs. Petrópolis: Editora Vozes, 1995. 
UCHÔA, Elizabeth; VIDAL, Jean Michel. Antropologia Médica: Elementos Conceituais E Metodológicos Para Uma Abordagem Da Saúde e da Doença. Cad. Saúde Públ., Rio De Janeiro, 10 (4): 497-504, Out/Dez, 1994

VIEIRA, Denise Leite; RIBEIRO, Marcelo; ROMANO, Marcos; LARANJEIRA, RONALDO R. Álcool E Adolescentes: Estudo para Implementar Políticas Municipais. In: Rev. Saúde Pública 2007;41(3).

ZERON, C.A. (Org.). Equipamentos, Usos e Costumes da Casa Brasileira. Fichário Ernani Silva Bruno. 1. Alimentação. São Paulo: Edusp / Imprensa Oficial / Museu Da Casa Brasileira, 2000

WOODWARD, Kathryn. Identidade e Diferenças: Uma Introdução Teórica e Conceitual. In: Identidade E Diferença: A Perspectiva Dos Estudos Culturais. Org. Silva, Tomaz Tadeu. Ed. Vozes. Petrópolis - RJ, 2004.

WORLD HEALTH ORGANIZATION - WHO. Global Status Report On Alcohol. Genebra: Who, 2004. 


\section{APÊNDICE I}

1. Eu queria que você me falasse sobre a sua experiência no trabalho em saúde indígena. Objetivo: Obter a percepção do profissional sobre o seu trabalho.

2. Como você entende as causas para o consumo da bebida alcoólica entre os Xerente e as consequências individuais e coletivas desse consumo? Objetivo: Conhecer as representações que o profissional de saúde indígena tem do consumo da bebida alcoólica entre os Xerente.

3. Como funcionam os trabalhos de enfrentamento ao consumo da bebida alcoólica nos serviços da saúde indígena? E em sua opinião deveriam funcionar de outra forma? Como? Objetivo: Conhecer as representações que o profissional de saúde indígena tem dos serviços ligados ao consumo do da bebida alcoólica.

4. Eu gostaria que você me falasse das principais dificuldades e também das principais facilidades que você tem para enfrentar o problema do uso/abuso de bebidas alcoólicas entre os índios Xerente. Objetivo: Conhecer os principais desafios (dificuldades e facilidades dos serviços). 
APÊNDICE II - Quadro de Categorias, Subcategorias e Inferências

Categorias referentes ao objetivo especifico 1 _ percepção sobre o uso do álcool

\begin{tabular}{|c|c|c|}
\hline Enunciados & Subcategorias & Sujeitos \\
\hline $\begin{array}{l}\text { "geralmente eles ficam mais... ficam... é... agressivos, né?! } \\
\text { Não são todos, mas quando eles têm agressividade, } \\
\text { geralmente tem o álcool envolvido...". }\end{array}$ & Agressividade & PS1 \\
\hline $\begin{array}{l}\text { "Quando ele está lá na aldeia, ele... a... ele é um índio } \\
\text { que... que trabalha planta a roça dele, caça, né?!... que } \\
\text { sustenta a família! Então, quando ele sai dessa situação, } \\
\text { que cai na bebida alcoólica, e fica ali um índio bêbado, } \\
\text { tombando, (...) a família está sofrendo, né?" }\end{array}$ & $\begin{array}{l}\text { Perda das funções } \\
\text { sociais e laborais }\end{array}$ & PS1 \\
\hline $\begin{array}{l}\text { (...) ficam agressivos, né?! Bate nas esposas, nas crianças, } \\
\text { entendeu? Ah! Que é o que normalmente não só o índio } \\
\text { faz como os não indígenas também tem essas... né?!... } \\
\text { essas consequências desagradáveis! }\end{array}$ & Agressividade & PS1 \\
\hline $\begin{array}{l}\text { Reforça o preconceito que as pessoas já tem contra o índio, } \\
\text { com o indígena, em relação ao indígena. Porque eles... } \\
\text { Quando, assim, se tem dez em uma etnia, por exemplo, } \\
\text { que bebe, que fica bêbado na rua e tal, as pessoas já } \\
\text { generalizam, né?! Eles acham que todos os indígenas são } \\
\text { desse jeito! }\end{array}$ & $\begin{array}{l}\text { Reforço do } \\
\text { preconceito } \\
\text { (valoração negativa }\end{array}$ & PS1 \\
\hline $\begin{array}{l}\text { Aí, o povo acha que vai resolver o problema... é... dando } \\
\text { aquele curso do povo do Alcoólicos Anônimos, porque } \\
\text { vieram um povo do Governo em uma época (...) Não } \\
\text { funciona, gente! }\end{array}$ & & PS2 \\
\hline $\begin{array}{l}\text { A bebida alcoólica bebem até cair. A bebida alcoólica, é } \\
\text { como nós também! É os problemas! O maior problema do } \\
\text { índio beber é a ocupação! Porque não tem! Alcoolismo? } \\
\text { Não (...) o índio bebe é porque ele não tem o que fazer! }\end{array}$ & $\begin{array}{l}\text { Perda das funções } \\
\text { sociais e laborais }\end{array}$ & PS2 \\
\hline $\begin{array}{l}\text { A facilidade é arrumar alguma coisa pra ele (...) pra ele se } \\
\text { ocupar! É a tal história: mente vazia, piscina de Satanás! } \\
\text { Né?! Se ele é desocupado, você vai fazer o que? Mendiga. }\end{array}$ & $\begin{array}{l}\text { Proposta de prevenção } \\
\text { - visão de prevenção }\end{array}$ & PS3 \\
\hline $\begin{array}{l}\text { Parou aquela rocinha, ele colhiam tudo ali, e aí, depois, ele } \\
\text { dizia assim: “Agora eu tenho de comer e pra beber! Agora } \\
\text { eu posso beber a vontade!” Então, assim, tem muitos deles } \\
\text { que fazem isso! Eles não bebem direto. Eles bebem por } \\
\text { época: os problemas familiares, que eles não sabem } \\
\text { resolver! }\end{array}$ & & PS3 \\
\hline $\begin{array}{l}\text { Eles são muito fraco pra conflito. Ou eles adoecem do } \\
\text { nada ou, então, vão beber muita cachaça por causa dos } \\
\text { conflitos! }\end{array}$ & $\begin{array}{l}\text { Inabilidade intrínseca } \\
\text { do indígena em lidar } \\
\text { com coflito }\end{array}$ & PS3 \\
\hline $\begin{array}{l}\text { Porque antes eles não eram assim! Eles bebiam de ano em } \\
\text { ano! Eles faziam a própria cachaça deles! Quando eu } \\
\text { cheguei aqui em Tocantinia no ano de } 95 \text {, você não via }\end{array}$ & $\begin{array}{l}\text { Modificação do } \\
\text { padrão de uso pela } \\
\text { aproximidade com a }\end{array}$ & PS4 \\
\hline
\end{tabular}




\begin{tabular}{|c|c|c|}
\hline essa indiarada aqui na rua bêbada! & cultura ocidental & \\
\hline $\begin{array}{l}\text { As consequências é briga na aldeia e, depois, as cirroses } \\
\text { hepáticas - os tumores igual nós! Não tem diferença! }\end{array}$ & Doenças físicas & PS4 \\
\hline $\begin{array}{l}\text { Por que o que é que esse povo come? Mandioca, arroz, } \\
\text { feijão, eles comem muito pouquinho! O que sustenta esse } \\
\text { povo pra aguentar uma semana de cachaça? }\end{array}$ & & PS4 \\
\hline $\begin{array}{l}\text { Às vezes, bebe o pai e a mãe! E, às vezes, bebe só o pai! E } \\
\text { bebe até álcool puro! Álcool. Álcool. Álcool. As mulheres, } \\
\text { elas bebem junto com o marido, né? }\end{array}$ & & PS4 \\
\hline $\begin{array}{l}\text { Eles vai pra uma festa e bebe uma vez, igual a gente! } \\
\text { Outro oferece um gole e, desse gole, se dana! (...) }\end{array}$ & & PS5 \\
\hline $\begin{array}{l}\text { Daí elas começam a beber! Só que as mulheres andam } \\
\text { menos embriagadas do que os homens! }\end{array}$ & & PS6 \\
\hline $\begin{array}{l}\text { É muito grande o consumo da bebida alcoólica! } \\
\text { Principalmente nas segundas-feiras! é... principalmente no } \\
\text { dia de segunda-feira - que é o dia em que eles iam pra } \\
\text { cidade, né?! }\end{array}$ & $\begin{array}{l}\text { Modificação do } \\
\text { padrão de uso pela } \\
\text { aproximidade com a } \\
\text { cultura ocidental }\end{array}$ & PS7 \\
\hline $\begin{array}{l}\text { (...) chegaram a me ameaçar, chegaram lá na unidade; eu } \\
\text { tive que sair de lá correndo, sabe?! Devido à bebida! Fora } \\
\text { da bebida, eram pessoas muito boas! Mas na hora em que } \\
\text { bebiam, assim, se transformavam }\end{array}$ & agressividade & PS8 \\
\hline $\begin{array}{l}\text { (...) algum artesanato que eles fazem, pra comprar } \\
\text { alimentação, e a mulher fica lá na aldeia. E ele vem, vende } \\
\text { e, antes dele fazer a compra pra ele levar, ele acaba } \\
\text { bebendo, né?!... gastando dinheiro daquele pouco que eles } \\
\text { ganham do artesanato, e a família fica lá com fome - a } \\
\text { mulher fica lá sofrendo necessidade junto com os filhos! } \\
\text { Né?! É o caso que vem, às vezes, a ver a desnutrição das } \\
\text { crianças, que o adulto sabe sair e procurar outra coisa, é a } \\
\text { criança }\end{array}$ & $\begin{array}{l}\text { Consequencia perda } \\
\text { da função provedora }\end{array}$ & \\
\hline $\begin{array}{l}\text { (...) facilidade deles, o acesso deles pra bebida está muito } \\
\text { fácil! Em um supermercado, eles conseguem comprar! Se } \\
\text { eles vão em um boteco, eles conseguem comprar! Né?! Se } \\
\text { eles vão em Miracema, eles conseguem comprar! Se eles } \\
\text { vão em qualquer lugar, eles conseguem comprar! }\end{array}$ & $\begin{array}{l}\text { Facilidade de acesso } \\
\text { ao álcool }\end{array}$ & PS9 \\
\hline $\begin{array}{l}\text { As causas... É... Eu acho, assim: a questão da ociosidade! } \\
\text { É Muitas vezes, a bebida é um atrativo, né; Chegou na } \\
\text { cidade, você tem ali livre acesso. Tocantínia é muito perto } \\
\text { da cidade! Quando eu chego na cidade, eu tenho como } \\
\text { comprar! O valor, também, da bebida - cerveja - hoje, } \\
\text { vamos supor, que é mais caro! Mas aquelas garrafinhas ali } \\
\text { de } 51 \text { são baratas! Não sei se ela chega a R } \$ 2,00 \text { (dois } \\
\text { reais), R\$ 2,50 (dois reais e cinquenta centavos). Então, } \\
\text { qualquer dinheirinho ali é fácil comprar! E uma garrafa } \\
\text { daquela já embebeda muito rápido! Então, assim: a }\end{array}$ & & PS9 \\
\hline
\end{tabular}




\begin{tabular}{|l|l|l|}
\hline dependência do álcool, & & \\
\hline $\begin{array}{l}\text { Eu acho que, assim, é a questão de falta de oportunidade, } \\
\text { com um refúgio ao álcool - ser um refúgio; a questão da } \\
\text { facilidade de conseguir encontrar; e, a dependência, que } \\
\text { não é fácil, né?! }\end{array}$ & & PS10 \\
\hline $\begin{array}{l}\text { Será se se eu tivesse uma qualidade de vida diferente, } \\
\text { opções de trabalho diferente, será se eu me refugiaria na } \\
\text { bebida? Né?! Então, é esse olhar que talvez a sociedade } \\
\text { precisa ver, e não só criticar o indígena que bebe que que bebe } \\
\text { e que fica na pro } \\
\text { dele quando saç da aldeia! }\end{array}$ & PS10 & \\
\hline $\begin{array}{l}\text { Além de problemas que pode gerar o uso de bebida } \\
\text { alcoólica: a hipertensão, né?!... cirrose, dentre outros }\end{array}$ & & \\
\hline $\begin{array}{l}\text { O índio bebe como consequência tem o aparecimento de } \\
\text { varias doenças. Eles ficam doentes ne }\end{array}$ & Doenças Físicas & \\
\hline $\begin{array}{l}\text {... Agressão. Violência, né?!... que pode gerar é uma certa } \\
\text { discriminação do grupo: quem bebe, é discriminado por } \\
\text { eles! }\end{array}$ & & PS10 \\
\hline $\begin{array}{l}\text { Emprego, né?! Não tem muito emprego. A briga deles } \\
\text { entre as comunidades é que se realmente vai colocar o } \\
\text { Fulano, vai tirar o Ciclano, porque eles precisam de } \\
\text { salário! }\end{array}$ & & \\
\hline
\end{tabular}




\section{Categorias referentes ao objetivo especifico 2 - Percepções sobre a cultura indígena em geral e Akwê-Xerente em especial.}

\begin{tabular}{|c|c|c|}
\hline Enunciados & Subcategorias & Sujeito \\
\hline $\begin{array}{l}\text { "o povo Xerente é diferente dos outros... do branco, do } \\
\text { povo como nós! Assim: eles são muito amorosos! Por outra } \\
\text { parte também, eles são muito exigentes! Ele gosta de você, } \\
\text { mas ele exige de você!" }\end{array}$ & $\begin{array}{l}\text { Elementos positivos } \\
\text { visto na cultura } \\
\text { indigena }\end{array}$ & PS2 \\
\hline $\begin{array}{l}\text { Eles querem ver uma proteção em você! (...) você se } \\
\text { identifica com eles, eles passam a depositar confiança em } \\
\text { você! Eles gostam das pessoas que se identificam com eles! }\end{array}$ & & PS2 \\
\hline $\begin{array}{l}\text { (...) eles tem a cultura deles, né?! E na cultura deles, estão } \\
\text { certo! Estão certo! Cada um na sua cultura não está certo? } \\
\text { Né?! Então, assim, eles discordam muitas coisas, assim, } \\
\text { que a gente acha... Pra gente é um absurdo, e pra eles é } \\
\text { normal! Entendeu? }\end{array}$ & $\begin{array}{l}\text { Reconhecimento da } \\
\text { necessidade de } \\
\text { relações interculturais }\end{array}$ & PS2 \\
\hline $\begin{array}{l}\text { E dentro da cultura deles também, eles tem outra coisa } \\
\text { também que eles gostam... eles querem tentar manipular a } \\
\text { gente! }\end{array}$ & & PS2 \\
\hline $\begin{array}{l}\text { Porque o índio, ele vive pra comer e morrer! Índio não tem } \\
\text { sonhos! Entendeu? Ele vive pra isso! }\end{array}$ & & PS2 \\
\hline $\begin{array}{l}\text { Então, as roças que eles fazem são em uns lugares muito } \\
\text { ruins; planta de qualquer jeito! Eu te digo porque eu } \\
\text { acompanhei! }\end{array}$ & & PS2 \\
\hline $\begin{array}{l}\text { Eu acho que nada dado é valorizado! Eles não valorizam } \\
\text { nem o que eles compram, imagine o que eles ganham! } \\
\text { Porque índio não tem valorização de nada! Eles não tem! } \\
\text { Eles compram uma camisa e daqui há poucos dias, me já } \\
\text { joga no mato; compra uma calça, um tênis! Eles não } \\
\text { valorizam nada! Pra eles, as coisas não tem valor! Eles não } \\
\text { são de valorizar as coisas! }\end{array}$ & & PS2 \\
\hline $\begin{array}{l}\text { (...) porque tem muito adultério! Muito muito mesmo! } \\
\text { Então, assim: aí vem os conflitos familiares! E eles não } \\
\text { aguentam conflito! }\end{array}$ & & PS2 \\
\hline $\begin{array}{l}\text { (...) na cultura indígena, a mulher, enquanto ela é virgem, } \\
\text { ela tem um valor! Perdeu a virgindade, ela não tem valor! É } \\
\text { muito discriminada! }\end{array}$ & $\begin{array}{l}\text { Lugar da mulher na } \\
\text { cultura }\end{array}$ & PS2 \\
\hline $\begin{array}{l}\text { E ela é mulher! Mulher não tem autoridade! Ela só baixa a } \\
\text { sua cabeça e a mãe fica morrendo de vergonha e o pai sai } \\
\text { morrendo de vergonha - como diz eles - e fica por isso } \\
\text { mesmo! Né?! }\end{array}$ & $\begin{array}{l}\text { Lugar da mulher na } \\
\text { cultura }\end{array}$ & PS2 \\
\hline $\begin{array}{l}\text { (...) na comunidade indígena, a gente não tem que esperar } \\
\text { que eles venham a se adaptar à gente; a gente tem que se } \\
\text { adaptar com eles, né?! Não adianta você chegar lá querendo } \\
\text { mudar as coisas de uma hora pra outra, porque você não } \\
\text { consegue, né?! Se você bater e insistir nisso, você vai pegar } \\
\text { uma resistência, não é?! }\end{array}$ & $\begin{array}{l}\text { Reconhecimento da } \\
\text { necessidade de } \\
\text { relações interculturais }\end{array}$ & PS3 \\
\hline $\begin{array}{l}\text { Então, eu tive um foi cinco anos de trabalho que eu aprendi } \\
\text { muito; aprendi muito com isso! Mas eu tive que me adaptar }\end{array}$ & & PS3 \\
\hline
\end{tabular}




\begin{tabular}{|c|c|c|}
\hline $\begin{array}{l}\text { a ele! Não esperar que eles me adaptassem ao meu jeito! } \\
\text { Entendeu? Lógico que a gente não vai se sujeitar a muito... } \\
\text { um tipo de coisa que acontece lá! Devagarzinho, a gente vai } \\
\text { tentando orientar eles como que é o jeito certo! }\end{array}$ & & \\
\hline $\begin{array}{l}\text { (...) dizem que o pajé, eles querem simplesmente uma coisa } \\
\text { financeira! Querem o dinheiro daquela família! Como a } \\
\text { família está desesperada porque a pessoa está doente, então, } \\
\text { eles gastam as coisas com o pajé! }\end{array}$ & $\begin{array}{l}\text { Elementos negativos } \\
\text { visto na cultura } \\
\text { indigena }\end{array}$ & PS4 \\
\hline $\begin{array}{l}\text { E aqui, eu vejo que tem muitos pajés; e o pajé, a gente tem } \\
\text { que respeitar; tem que respeitar! }\end{array}$ & $\begin{array}{l}\text { Constestação de } \\
\text { saberes tradicionais }\end{array}$ & PS4 \\
\hline $\begin{array}{l}\text { A gente já teve óbito de crianças por causa de pajelanças, } \\
\text { né?! O uso de ervas muito forte! Às vezes, a forma deles } \\
\text { utilizarem fumaças, né?! Âs vezes, inala! E tem ali um } \\
\text { problema agravante - pulmonar, um exemplo - que vai o } \\
\text { quadro vai piorar! É... Pacientes que saíram do hospital } \\
\text { porque queriam voltar pra aldeia onde iria ter a pajelança! }\end{array}$ & & PS4 \\
\hline $\begin{array}{l}\text { A culpa do óbito foi do pajé!" Não! Porque é a cultura } \\
\text { deles! O pajé, ele acha que aquilo é certo! Né?! E a gente } \\
\text { tem que respeitar a postura e a questão de olhar eles como } \\
\text { uma pessoa de referência em relação à saúde! Mas, ao } \\
\text { mesmo tempo, a gente tem que mostrar que as formas de } \\
\text { eles utilizarem hoje não são mais as... as corretas, né?! A } \\
\text { gente sabe que tem dificuldades porque alguns não aceitam, } \\
\text { né?! Mas, a gente tem que saber trabalhar! }\end{array}$ & $\begin{array}{l}\text { Constestação de } \\
\text { saberes tradicionais }\end{array}$ & PS4 \\
\hline $\begin{array}{l}\text { Porque hoje, o indígena está muito, assim, remédio, } \\
\text { remédio, remédio, e esqueceu da tradição... da Medicina } \\
\text { tradicional - que, nós temos aí uma reserva cheia e rica de } \\
\text { plantas e de coisas que eles podem utilizar ainda, né?! E } \\
\text { esqueceram! E eu acho que isso também é culpa nossa, de } \\
\text { certa forma, em introduzir isso na cultura deles, né?! }\end{array}$ & $\begin{array}{l}\text { Critica à perda das } \\
\text { tradições pelos } \\
\text { indigenas }\end{array}$ & PS4 \\
\hline $\begin{array}{l}\text { (...) uma comunidade que requer atenção, requer } \\
\text { entendimento, requer compreensão e é um povo que } \\
\text { necessita realmente de um olhar diferente - não só o } \\
\text { Xerente, mas eu acho que todas as etnias! }\end{array}$ & & PS4 \\
\hline $\begin{array}{l}\text { eu estava na Funil, o cacique esteve muito doente, direto, e } \\
\text { foram vários pajés! Então, assim, eu estava lá, eu assistia e } \\
\text { só ficava na minha! Então, respeitava o momento deles! }\end{array}$ & & PS5 \\
\hline $\begin{array}{l}\text { Já tem uns que acredita no pajé! Já tem outros que acredita } \\
\text { na saúde, né?! Então, tem vez que eles procuram... Aqueles } \\
\text { que mais acreditam no pajé, primeiro, eles vão no pajé! } \\
\text { Depois se eles não conseguirem a cura, eles vão na saúde! } \\
\text { Do mesmo jeito é os que vai na saúde e se vai, vai, vai e } \\
\text { não consegue a cura, eles vão atrás do pajé! }\end{array}$ & $\begin{array}{l}\text { Possibilidades de } \\
\text { articulação de saberes }\end{array}$ & PS6 \\
\hline $\begin{array}{l}\text { "Mas você vai e conversa com o pajé; você explica que o } \\
\text { pajé vai fazer a parte dele, e você também vai fazer a sua. } \\
\text { Porque o pajé manda tirar o remédio! Você entendeu? E } \\
\text { bota só o dele!" }\end{array}$ & $\begin{array}{l}\text { Possibilidades de } \\
\text { articulação de saberes } \\
\text { e } \\
\text { Constestação de } \\
\text { saberes tradicionais }\end{array}$ & PS2 \\
\hline
\end{tabular}


Categorias referentes ao objetivo especifico 3 - Dificuldades e Facilidades no Serviço

\begin{tabular}{|c|c|c|}
\hline Enunciados & Subcategorias & Sujeito \\
\hline $\begin{array}{l}\text { "... porque a saúde publica, ela fica só com o produto final, } \\
\text { que é o indígena, com as consequências do consumo da } \\
\text { bebida, né?!" }\end{array}$ & & PS1 \\
\hline $\begin{array}{l}\text { "essa situação, a saúde, por si só, é muito totalmente } \\
\text { impotente, na minha visão, né?!" }\end{array}$ & $\begin{array}{l}\text { Necessidade de } \\
\text { apoio a atuação dos } \\
\text { profissionais }\end{array}$ & PS1 \\
\hline $\begin{array}{l}\text { "Eu penso que seria, né?!... juntar todo mundo e pensar e criar } \\
\text { uma política, né?! (...) política bem definida, clara, né?! E } \\
\text { onde todos... vários... pessoas, vários atores estivessem } \\
\text { envolvidos não só pra instituir a política, mas também pra } \\
\text { respeitar essa política, né?! Então, teria que ter uma política } \\
\text { pública, né?!... assegurada, sistematizada, pra garantir isso!” }\end{array}$ & $\begin{array}{l}\text { Necessidade de } \\
\text { políticas programas } \\
\text { específicos }\end{array}$ & PS1 \\
\hline $\begin{array}{l}\text { "Querer só não resolve! Por exemplo: não adianta eu querer } \\
\text { ou você querer ou alguém querer, né?! Tem que querer, mas } \\
\text { tem que ter um respaldo, juntar forças e tal, né?! (...) e criar } \\
\text { realmente uma política voltada para isso! Eu acho que, no } \\
\text { momento, eu penso que não existe!" }\end{array}$ & $\begin{array}{l}\text { Necessidade de } \\
\text { apoio a atuação dos } \\
\text { profissionais }\end{array}$ & PS1 \\
\hline $\begin{array}{l}\text { "Eu acho que ainda é um processo; ainda não acharam o } \\
\text { caminho... De trabalhar com a população, né?!... que tem essa } \\
\text { cultura diferenciada, né?!... Eu acho que falta ainda muito... } \\
\text { é... melhorar a relação, né?!... e definir melhor o papel de cada } \\
\text { um (....)" }\end{array}$ & $\begin{array}{l}\text { Necessidade de } \\
\text { atenção a saúde } \\
\text { culturalmente } \\
\text { adequado }\end{array}$ & PS1 \\
\hline $\begin{array}{l}\text { "Eu acho que ainda a saúde indígena é um processo. Não } \\
\text { vejo, assim, que tenha avançado muito!" }\end{array}$ & & PS1 \\
\hline $\begin{array}{l}\text { "e eu não vejo, assim, dificuldade de lidar com eles como } \\
\text { profissional! Né?! Não... Não tenho nenhuma dificuldade. } \\
\text { Eles aceitam bem! Tem algumas resistências(...) Tem } \\
\text { resistência pra algumas coisas, né?! É natural, como nós } \\
\text { também temos!" }\end{array}$ & & PS1 \\
\hline $\begin{array}{l}\text { "(...) a vontade de melhorar a qualidade, de dar à saúde } \\
\text { indígena qualidade na assistência, sabe?! Na assistência da } \\
\text { qualidade. É o que eu acho que esse é o grande desafio!" }\end{array}$ & $\begin{array}{l}\text { Melhoria da } \\
\text { qualidade e acesso } \\
\text { aos cuidados a } \\
\text { saúde }\end{array}$ & PS1 \\
\hline $\begin{array}{l}\text { “(...) é preciso que tenha uma instituição que esteja disposto a } \\
\text { conhecer a realidade, a respeitar os limites, né?!... da gente, as } \\
\text { barreiras linguísticas... é... e querer fazer uma coisa que é } \\
\text { absolutamente normal - fazer bem feito um serviço! } \\
\text { Entendeu? Então, eu acho que falta uma instituição, porque } \\
\text { hoje eu não vejo, sinceramente, né?!” }\end{array}$ & $\begin{array}{l}\text { Necessidade de } \\
\text { atenção a saúde } \\
\text { culturalmente } \\
\text { adequado }\end{array}$ & PS1 \\
\hline $\begin{array}{l}\text { "Muita insegurança, muito medo, muito pouco conhecimento, } \\
\text { né?!" }\end{array}$ & & PS1 \\
\hline $\begin{array}{l}\text { "É porque eles são uma população que tem muito esse espírito } \\
\text { da coletividade. Né?! Eles agregam isso! Então, como você é } \\
\text { saúde pública, né?!... então, você precisa muito desse espírito }\end{array}$ & & PS1 \\
\hline
\end{tabular}




\begin{tabular}{|c|c|c|}
\hline da coletividade" & & \\
\hline $\begin{array}{l}\text { "as colegas profissionais, elas acham que elas estão ali para } \\
\text { dar remédio! E não é isso! Na saúde indígena, não é isso! A } \\
\text { saúde indígena é você ir na casa dele e conhecer ele! }\end{array}$ & $\begin{array}{l}\text { Necessidade de } \\
\text { atenção a saúde } \\
\text { culturalmente } \\
\text { adequado }\end{array}$ & PS2 \\
\hline $\begin{array}{l}\text { "Na hora de você sentar em uma roda e ter aquele bate papo, é } \\
\text { outra coisa! E naqueles bate papo, você vai indo ali e você vai } \\
\text { observando, e eles vão começando a te falar o que ele está } \\
\text { sofrendo! Aí ele confia em você! Aí ele lhe conta! Digamos: a } \\
\text { poligamia; a poligamia é muito grande, né?! Na saúde } \\
\text { indígena, se faz necessário!" }\end{array}$ & & PS2 \\
\hline $\begin{array}{l}\text { "Mas você vai e conversa com o pajé; você explica que o pajé } \\
\text { vai fazer a parte dele, e você também vai fazer a sua. Porque o } \\
\text { pajé manda tirar o remédio! Você entendeu? E bota só o } \\
\text { dele!" }\end{array}$ & & PS2 \\
\hline $\begin{array}{l}\text { "foi um pouco difícil porque eu não tinha o conhecimento, } \\
\text { assim, como que era, né?! A gente vai trabalhar pensando que } \\
\text { é um tipo de trabalho e, quando chega lá, é diferente, } \\
\text { entendeu? Aí eu estava muito ansioso, mas, de repente, a } \\
\text { gente vai se interando, né?! É... A gente via muita necessidade } \\
\text { dentro da reserva." }\end{array}$ & & PS3 \\
\hline $\begin{array}{l}\text { "E como a comunidade é grande, né?! São cinquenta e seis } \\
\text { aldeias aí no Município, né?! Tem delas que tem um acesso } \\
\text { difícil." }\end{array}$ & $\begin{array}{l}\text { Melhoria da } \\
\text { qualidade e acesso } \\
\text { aos cuidados a } \\
\text { saúde }\end{array}$ & PS4 \\
\hline $\begin{array}{l}\text { “(...) é um desafio que só quem trabalha na saúde indígena é } \\
\text { quem gosta; quem ama! Quem na ama, quem não gosta, não } \\
\text { aguenta nem um ano - vamos, assim, dizer! É... E a minha } \\
\text { experiência é uma experiência boa, né?!” }\end{array}$ & & PS5 \\
\hline $\begin{array}{l}\text { "Especialização que eu estou fazendo agora em Saúde } \\
\text { Indígena, a gente vê a diversidade cultural; a gente tem que } \\
\text { saber lidar com isso; e até mesmo a questão das doenças, né?! } \\
\text { (...) a questão de lidar com a saúde que é uma realidade } \\
\text { totalmente diferente da cidade, do branco, né?!" }\end{array}$ & $\begin{array}{l}\text { Necessidade de } \\
\text { atenção a saúde } \\
\text { culturalmente } \\
\text { adequado }\end{array}$ & PS5 \\
\hline
\end{tabular}




\begin{tabular}{|c|c|c|}
\hline \multicolumn{3}{|c|}{1 Categorias prévias - Causas do uso do álcool } \\
\hline Subcategoria & Unidade de referência & Sujeito \\
\hline \multirow{3}{*}{$\begin{array}{l}\text { 1.1 Perdas das funções } \\
\text { sociais laborais }\end{array}$} & $\begin{array}{l}\text { "O maior problema do índio beber é a ocupação! } \\
\text { Porque não tem! Alcoolismo? Não (...) o índio bebe é } \\
\text { porque ele não tem o que fazer!" }\end{array}$ & PS2 \\
\hline & $\begin{array}{l}\text { "Será se se eu tivesse uma qualidade de vida diferente, } \\
\text { opçôes de trabalho diferente, será se eu me refugiaria } \\
\text { na bebida?" }\end{array}$ & PS10 \\
\hline & $\begin{array}{l}\text { "Quando ele está lá na aldeia, ele... a... ele é um índio } \\
\text { que... que trabalha, planta a roça dele, caça, né?!... } \\
\text { que sustenta a família! Então, quando ele sai dessa } \\
\text { situação, que cai na bebida alcoólica, e fica ali um } \\
\text { indio bêbado, tombando, (...) a família está sofrendo, } \\
\text { né?" }\end{array}$ & PS1 \\
\hline \multirow{2}{*}{$\begin{array}{l}\text { 1.2 Modificação do padrão } \\
\text { de uso e facilidade de } \\
\text { acesso pela aproximidade } \\
\text { com a cultura ocidental. }\end{array}$} & $\begin{array}{l}\text { (...) facilidade deles, o acesso deles pra bebida está } \\
\text { muito fácil! Em um supermercado, eles conseguem } \\
\text { comprar! Se eles vão em um boteco, eles conseguem } \\
\text { comprar! Né?! Se eles vão em Miracema, eles } \\
\text { conseguem comprar! Se eles vão em qualquer lugar, } \\
\text { eles conseguem comprar! }\end{array}$ & PS9 \\
\hline & $\begin{array}{l}\text { Porque antes eles não eram assim! Eles bebiam de ano } \\
\text { em ano! Eles faziam a própria cachaça deles! Quando } \\
\text { eu cheguei aqui em Tocantinia no ano de 95, você não } \\
\text { via essa indiarada aqui na rua bêbada! }\end{array}$ & PS4 \\
\hline \multirow{2}{*}{$\begin{array}{l}\text { 1.3 Inabilidade intrínseca } \\
\text { do indígena em lidar com } \\
\text { conflito }\end{array}$} & $\begin{array}{l}\text { Eles são muito fraco pra conflito. Ou eles adoecem do } \\
\text { nada ou, então, vão beber muita cachaça por causa } \\
\text { dos conflitos! (...)Eles bebem por época: os problemas } \\
\text { familiares, que eles não sabem resolver! }\end{array}$ & PS3 \\
\hline & $\begin{array}{l}\text { (...) porque tem muito adultério! Muito muito mesmo! } \\
\text { Então, assim: aí vem os conflitos familiares! E eles não } \\
\text { aguentam conflito! }\end{array}$ & PS2 \\
\hline
\end{tabular}




\begin{tabular}{|c|c|c|}
\hline \multicolumn{3}{|c|}{2 Categorias prévias - Consequência do uso do álcool } \\
\hline \multirow{3}{*}{$\begin{array}{l}2.1 \\
\text { Agressividade }\end{array}$} & $\begin{array}{l}\text { "geralmente eles ficam mais... ficam... é... agressivos, né?! Não são } \\
\text { todos, mas quando eles tem agressividade, geralmente tem o álcool } \\
\text { envolvido..." (...)Bate nas esposas, nas crianças, entendeu? Ah! } \\
\text { Que é o que normalmente não só o índio faz. }\end{array}$ & PS1 \\
\hline & "As consequências é briga na aldeia" & PS4 \\
\hline & $\begin{array}{l}\text { (...) chegaram a me ameaçar, chegaram lá na unidade; eu tive que } \\
\text { sair de lá correndo, sabe?! Devido à bebida! Fora da bebida, eram } \\
\text { pessoas muito boas! Mas na hora em que bebiam, assim, se } \\
\text { transformavam }\end{array}$ & PS8 \\
\hline $\begin{array}{l}2.2 \text { Perda da } \\
\text { função } \\
\text { provedora }\end{array}$ & $\begin{array}{l}\text { (...) algum artesanato que eles fazem, pra comprar alimentação, e a } \\
\text { mulher fica lá na aldeia. E ele vem, vende e, antes dele fazer a } \\
\text { compra pra ele levar, ele acaba bebendo, né?!... gastando dinheiro } \\
\text { daquele pouco que eles ganham do artesanato, e a família fica lá } \\
\text { com fome }\end{array}$ & PS1 \\
\hline $\begin{array}{l}2.3 \text { Reforço do } \\
\text { preconceito }\end{array}$ & $\begin{array}{l}\text { Reforça o preconceito que as pessoas já tem contra o índio, com o } \\
\text { indígena, em relação ao indígena. Porque eles... Quando, assim, se } \\
\text { tem dez em uma etnia, por exemplo, que bebe, que fica bêbado na } \\
\text { rua e tal, as pessoas já generalizam, né?! Eles acham que todos os } \\
\text { indígenas são desse jeito! }\end{array}$ & PS1 \\
\hline \multirow{2}{*}{$\begin{array}{l}2.4 \text { Doenças } \\
\text { físicas }\end{array}$} & $\begin{array}{l}\text { E, depois, as cirroses hepáticas - os tumores igual nós! Não tem } \\
\text { diferença! }\end{array}$ & PS4 \\
\hline & $\begin{array}{l}\text { O indio bebe como consequência tem o aparecimento de varias } \\
\text { doenças. Eles ficam doentes... }\end{array}$ & PS3 \\
\hline
\end{tabular}




\begin{tabular}{|c|c|c|}
\hline \multicolumn{3}{|c|}{3 Categorias Prévias - Relações interculturais em torno da atenção a saúde } \\
\hline \multirow{3}{*}{$\begin{array}{l}\text { 3.1 Elementos Positivos } \\
\text { e Negativos vistos na } \\
\text { cultura indígena }\end{array}$} & $\begin{array}{l}\text { "o povo Xerente é diferente dos outros... do branco, do } \\
\text { povo como nós! Assim: eles são muito amorosos! Por outra } \\
\text { parte também, eles são muito exigentes! Ele gosta de você, } \\
\text { mas ele exige de você!" }\end{array}$ & PS2 \\
\hline & $\begin{array}{l}\text { E dentro da cultura deles também, eles tem outra coisa } \\
\text { também que eles gostam... eles querem tentar manipular a } \\
\text { gente! }\end{array}$ & PS2 \\
\hline & $\begin{array}{l}\text { (...) na cultura indígena, a mulher, enquanto ela é virgem, } \\
\text { ela tem um valor! Perdeu a virgindade, ela não tem valor! É } \\
\text { muito discriminada! (...) a mulher não tem autoridade! Ela } \\
\text { só baixa a cabeça }\end{array}$ & PS2 \\
\hline \multirow{2}{*}{$\begin{array}{l}\text { 3.1 Reconhecimento da } \\
\text { necessidade de } \\
\text { estabelecer relações } \\
\text { interculturais }\end{array}$} & $\begin{array}{l}\text { (...) eles tem a cultura deles, né?! E na cultura deles, estão } \\
\text { certo! Estão certo! Cada um na sua cultura não está certo? } \\
\text { Né?! Então, assim, eles discordam muitas coisas, assim, que } \\
\text { a gente acha... Pra gente é um absurdo, e pra eles é normal! } \\
\text { Entendeu? }\end{array}$ & PS2 \\
\hline & $\begin{array}{l}\text { (...) na comunidade indígena, a gente não tem que esperar } \\
\text { que eles venham a se adaptar à gente; a gente tem que se } \\
\text { adaptar com eles, né?! Não adianta você chegar lá } \\
\text { querendo mudar as coisas de uma hora pra outra, porque } \\
\text { você não consegue, né?! Se você bater e insistir nisso, você } \\
\text { vai pegar uma resistência, não é?! }\end{array}$ & PS3 \\
\hline \multirow[t]{2}{*}{$\begin{array}{l}\text { 3.2 Possibilidade de } \\
\text { articulação de saberes }\end{array}$} & $\begin{array}{l}\text { Já tem uns que acredita no pajé! Já tem outros que acredita } \\
\text { na saúde, né?! Então, tem vez que eles procuram... Aqueles } \\
\text { que mais acreditam no pajé, primeiro, eles vão no pajé! } \\
\text { Depois se eles não conseguirem a cura, eles vão na saúde! } \\
\text { Do mesmo jeito é os que vai na saúde e se vai, vai, vai e não } \\
\text { consegue a cura, eles vão atrás do pajé! }\end{array}$ & PS6 \\
\hline & $\begin{array}{l}\text { "Mas você vai e conversa com o pajé; você explica que o } \\
\text { pajé vai fazer a parte dele, e você também vai fazer a sua. }\end{array}$ & PS2 \\
\hline $\begin{array}{l}3.3 \text { Critica a perda das } \\
\text { tradições pelos indigenas }\end{array}$ & $\begin{array}{l}\text { Porque hoje, o indígena está muito, assim, remédio, } \\
\text { remédio, remédio, e esqueceu da tradição... da Medicina } \\
\text { tradicional-que, nós temos aí uma reserva cheia e rica de } \\
\text { plantas e de coisas que eles podem utilizar ainda, né?! E } \\
\text { esqueceram! E eu acho que isso também é culpa nossa, de } \\
\text { certa forma, em introduzir isso na cultura deles, né?! }\end{array}$ & PS4 \\
\hline \multirow{3}{*}{$\begin{array}{l}\text { 3.4 Contestação de } \\
\text { saberes tradicionais }\end{array}$} & $\begin{array}{l}\text { O pajé, ele acha que aquilo é certo! Né?! E a gente tem que } \\
\text { respeitar a postura e a questão de olhar eles como uma } \\
\text { pessoa de referência em relação à saúde! Mas, ao mesmo } \\
\text { tempo, a gente tem que mostrar que as formas de eles } \\
\text { utilizarem hoje não são mais as... as corretas, né?! }\end{array}$ & PS4 \\
\hline & $\begin{array}{l}\text { (...) dizem que o pajé, eles querem simplesmente uma coisa } \\
\text { financeira! Querem o dinheiro daquela família! Como a } \\
\text { família está desesperada porque a pessoa está doente, } \\
\text { então, eles gastam as coisas com o pajé! }\end{array}$ & PS4 \\
\hline & $\begin{array}{l}\text { Porque o pajé manda tirar o remédio! Você entendeu? E } \\
\text { bota só o dele!"” }\end{array}$ & PS2 \\
\hline
\end{tabular}




\begin{tabular}{|c|c|c|}
\hline \multicolumn{3}{|c|}{4 Categorias Prévias - Proposta de enfrentamento na atenção à saúde } \\
\hline $\begin{array}{l}\text { 4.1 Necessidade de } \\
\text { politicas e programas } \\
\text { específicos }\end{array}$ & $\begin{array}{l}\text { "Eu penso que seria juntar todo mundo e pensar e criar uma } \\
\text { política (...) política bem definida, clara. E onde todos... } \\
\text { vários... pessoas, vários atores estivessem envolvidos não só } \\
\text { pra instituir a política, mas também pra respeitar essa } \\
\text { política. Então, teria que ter uma política pública }\end{array}$ & PS1 \\
\hline \multirow[b]{2}{*}{$\begin{array}{l}\text { 4.2 Necessidade de } \\
\text { apoio as necessidades } \\
\text { dos profissionais }\end{array}$} & $\begin{array}{l}\text { "essa situação, a saúde, por si só, é muito totalmente } \\
\text { impotente, na minha visão, né?!" }\end{array}$ & PS1 \\
\hline & $\begin{array}{l}\text { "Querer só não resolve! Por exemplo: não adianta eu } \\
\text { querer ou você querer ou alguém querer, né?! Tem que } \\
\text { querer, mas tem que ter um respaldo, juntar forças e tal, } \\
\text { né?! (...) e criar realmente uma política voltada para isso! } \\
\text { Eu acho que, no momento, eu penso que não existe!"” }\end{array}$ & PS1 \\
\hline \multirow{3}{*}{$\begin{array}{l}4.3 \text { Necessidade de } \\
\text { atenção a saúde } \\
\text { culturalmente } \\
\text { adequada }\end{array}$} & $\begin{array}{l}\text { "Eu acho que ainda é um processo; ainda não acharam o } \\
\text { caminho (...) De trabalhar com a população, que tem essa } \\
\text { cultura diferenciada, né?!... Eu acho que falta ainda muito... } \\
\text { é... melhorar a relação, e definir melhor o papel de cada um } \\
\text { (...)" }\end{array}$ & PS1 \\
\hline & $\begin{array}{l}\text { “(...) é preciso que tenha uma instituição que esteja disposto } \\
\text { a conhecer a realidade, a respeitar os limites, né?!... da } \\
\text { gente, as barreiras linguísticas... }\end{array}$ & PS1 \\
\hline & $\begin{array}{l}\text { a gente vê a diversidade cultural; a gente tem que saber } \\
\text { lidar com isso; e até mesmo a questão das doenças, né?! (...) } \\
\text { a questão de lidar com a saúde que é uma realidade } \\
\text { totalmente diferente da cidade, do branco }\end{array}$ & PS5 \\
\hline \multirow{3}{*}{$\begin{array}{l}\text { 4.4 Necessidades de } \\
\text { melhorias da qualidade } \\
\text { e acesso aos cuidados } \\
\text { de saúde }\end{array}$} & $\begin{array}{l}\text { "(...) a vontade de melhorar a qualidade, de dar à saúde } \\
\text { indígena qualidade na assistência, sabe?! Na assistência da } \\
\text { qualidade. É o que eu acho que esse é o grande desafio!" }\end{array}$ & PS1 \\
\hline & $\begin{array}{l}\text { "as colegas profissionais, elas acham que elas estão ali } \\
\text { para dar remédio! E não é isso! Na saúde indígena, não é } \\
\text { isso! A saúde indígena é você ir na casa dele e conhecer ele! }\end{array}$ & PS2 \\
\hline & $\begin{array}{l}\text { "E como a comunidade é grande, né?! São cinquenta e seis } \\
\text { aldeias aí no Município, né?! Tem delas que tem um acesso } \\
\text { difícil." }\end{array}$ & PS4 \\
\hline \multirow[b]{2}{*}{$\begin{array}{l}\text { 4.5 Proposta de } \\
\text { prevenção }\end{array}$} & $\begin{array}{l}\text { A facilidade é arrumar alguma coisa pra ele (...) pra ele se } \\
\text { ocupar! É a tal história: mente vazia, piscina de Satanás! } \\
\text { Né?! Se ele é desocupado, você vai fazer o que? Mendiga. }\end{array}$ & SP3 \\
\hline & $\begin{array}{l}\text { Será se se eu tivesse uma qualidade de vida diferente, } \\
\text { opções de trabalho diferente, será se eu me refugiaria na } \\
\text { bebida? Né?! Então, é esse olhar que talvez a sociedade } \\
\text { precisa ver, e não só criticar o indígena que bebe, que bebe } \\
\text { e que fica na praça?! A gente tem que entender a realidade } \\
\text { dele quando sai da aldeia! }\end{array}$ & PS10 \\
\hline
\end{tabular}

